OPEN ACCESS

Edited by:

Frank S. Gilliam

University of West Florida,

United States

Reviewed by:

Albertus J. Smit,

University of the Western Cape,

South Africa

H. Dail Laughinghouse IV, University of Florida, United States

${ }^{*}$ Correspondence: Cynthia Ann Heil

cheil@mote.org

Specialty section:

This article was submitted to Biogeography and Macroecology, a section of the journal

Frontiers in Ecology and Evolution

Received: 24 December 2020 Accepted: 22 April 2021

Published: 17 June 2021

Citation:

Heil CA and Muni-Morgan AL (2021) Florida's Harmful Algal Bloom

(HAB) Problem: Escalating Risks to Human, Environmental and Economic Health With Climate Change. Front. Ecol. Evol. 9:646080. doi: $10.3389 /$ fevo.2021.646080

\section{Florida's Harmful Algal Bloom (HAB) Problem: Escalating Risks to Human, Environmental and Economic Health With Climate Change}

\author{
Cynthia Ann Heil'* and Amanda Lorraine Muni-Morgan ${ }^{1,2}$
}

'Mote Marine Laboratory \& Aquarium, Sarasota, FL, United States, ${ }^{2}$ Soil and Water Quality Laboratory, Gulf Coast Research and Education Center, Institute of Food and Agricultural Sciences, University of Florida, Wimauma, FL, United States

Harmful Algal Blooms (HABs) pose unique risks to the citizens, stakeholders, visitors, environment and economy of the state of Florida. Florida has been historically subjected to reoccurring blooms of the toxic marine dinoflagellate Karenia brevis (C. C. Davis) G. Hansen \& Moestrup since at least first contact with explorers in the 1500's. However, ongoing immigration of more than 100,000 people year ${ }^{-1}$ into the state, elevated population densities in coastal areas with attendant rapid, often unregulated development, coastal eutrophication, and climate change impacts (e.g., increasing hurricane severity, increases in water temperature, ocean acidification and sea level rise) has likely increased the occurrence of other HABs, both freshwater and marine, within the state as well as the number of people impacted by these blooms. Currently, over 75 freshwater, estuarine, coastal and marine HAB species are routinely monitored by state agencies. While only blooms of $K$. brevis, the dinoflagellate Pyrodinium bahamense (Böhm) Steidinger, Tester, and Taylor and the diatom Pseudo-nitzschia spp. have resulted in closure of commercial shellfish beds, other HAB species, including freshwater and marine cyanobacteria, pose either imminent or unknown risks to human, environmental and economic health. HAB related human health risks can be classified into those related to consumption of contaminated shellfish and finfish, consumption of or contact with bloom or toxin contaminated water or exposure to aerosolized HAB toxins. While acute human illnesses resulting from consumption of brevetoxin-, saxitoxin-, and domoic acid-contaminated commercial shellfish have been minimized by effective monitoring and regulation, illnesses due to unregulated toxin exposures, e.g., ciguatoxins and cyanotoxins, are not well documented or understood. Aerosolized HAB toxins potentially impact the largest number of people within Florida. While short-term (days to weeks) impacts of aerosolized brevetoxin exposure are well documented (e.g., decreased respiratory function for at-risk subgroups such as asthmatics), little is known of longer term (>1 month) impacts of exposure or the risks posed by aerosolized cyanotoxin [e.g., microcystin, $\beta$ - $N$-methylamino-L-alanine (BMAA)] exposure. Environmental risks of $K$. brevis blooms are the best studied of Florida HABs and include acute exposure impacts such as significant dies-offs of fish, 
marine mammals, seabirds and turtles, as well as negative impacts on larval and juvenile stages of many biota. When K. brevis blooms are present, brevetoxins can be found throughout the water column and are widespread in both pelagic and benthic biota. The presence of brevetoxins in living tissue of both fish and marine mammals suggests that food web transfer of these toxins is occurring, resulting in toxin transport beyond the spatial and temporal range of the bloom such that impacts of these toxins may occur in areas not regularly subjected to blooms. Climate change impacts, including temperature effects on cell metabolism, shifting ocean circulation patterns and changes in $\mathrm{HAB}$ species range and bloom duration, may exacerbate these dynamics. Secondary $\mathrm{HAB}$ related environmental impacts are also possible due to hypoxia and anoxia resulting from elevated bloom biomass and/or the decomposition of HAB related mortalities. Economic risks related to HABs in Florida are diverse and impact multiple stakeholder groups. Direct costs related to human health impacts (e.g., increased hospital visits) as well as recreational and commercial fisheries can be significant, especially with widespread sustained HABs. Recreational and tourism-based industries which sustain a significant portion of Florida's economy are especially vulnerable to both direct (e.g., declines in coastal hotel occupancy rates and restaurant and recreational users) and indirect (e.g., negative publicity impacts, associated job losses) impacts from HABs. While risks related to $K$. brevis blooms are established, Florida also remains susceptible to future HABs due to large scale freshwater management practices, degrading water quality, potential transport of HABs between freshwater and marine systems and the state's vulnerability to climate change impacts.

Keywords: HAB, Florida, Karenia brevis, climate change, risks, toxins

\section{INTRODUCTION}

Phytoplankton, the microscopic algae found in freshwater, estuarine and marine waters, are critically important to both human and the planet's health. They form the basis of aquatic food webs, and thus are essential for the secondary production of shellfish and finfish that provide $\sim 16 \%$ of the world's protein supply (Cato, 1998). They are responsible for $\sim 50 \%$ of global photosynthesis (Longhurst et al., 1995; Field et al., 1998; Beardall et al., 2009), producing between $50-85 \%$ of the $\mathrm{O}_{2}$ in the atmosphere. Their role in sequestering atmospheric $\mathrm{CO}_{2}$ through photosynthesis and transferring this carbon (C) to ocean sediments is considered a major buffer of climate change impacts (Falkowski, 2012). A small subset of the estimated 5,000 (Sournia et al., 1991; Sournia, 1995; Tett and Barton, 1995) to 100,000 (Round and Crawford, 1984) phytoplankton species in the ocean form blooms, an accumulation of cells of one or more species that occurs through physical concentration and/or in situ cell growth, with approximately 300 species involved in harmful bloom events (Berdalet et al., 2016). Blooms are considered to be a harmful algal bloom (HAB) when they become harmful to human, ecosystem or economic health. Harmful is a broad term, however, and can include both direct (e.g., damage due to cell morphology, toxins or other substances) and indirect (e.g., $\mathrm{O}_{2}$ depletion due to respiratory demands of high biomass) impacts of cells. The concentration of cells of an individual species that constitutes a bloom is also highly variable. Smayda (1997) argues that biomass alone is insufficient to describe a bloom as harmful and that the environmental consequences of a bloom must be considered. A smaller subset of these HABs, $\sim 2 \%$ of total species (Sournia, 1995; Knap et al., 2002), produce secondary metabolites which can be toxic or fatal. Although the majority of toxic HAB species are Dinophyceae, species of Bacillariophyceae and Raphidophyceae, some Prasinophyceae as well as photosynthetic bacteria (Cyanophyceae/Cyanobacteria) can be toxic.

Within the past 30 years, there has been increasing scientific and public focus on and concern about HABs for several reasons. In the late 1980's and early 1990's, a trend of increasing frequency, geographical distribution and abundance of some HAB species, primarily dinoflagellates, was recognized (Anderson, 1989; Maclean, 1989; Smayda, 1989, 1990). These trends have increasingly been documented for additional species and groups (e.g., Cyanophyceae, Paerl and Paul, 2012; Harke et al., 2016) in subsequent years (Chinain et al., 2020a; Yñiguez et al., 2020; Anderson et al., 2021), and HABs are now an almost routine occurrence among much of the world's coastal waters. $\mathrm{HAB}$ increases are attributed to a variety of reasons that vary with the species and the geographical areas involved (Anderson, 1989; Hallegraeff, 1993; Burkholder, 1998; Glibert et al., 2005; Glibert and Burkholder, 2006). These include increasing coastal nutrient inputs and eutrophication, coastal development, industrial and agricultural intensification (Smayda, 1990; Anderson et al., 2002, 2008; Glibert et al., 2006; Heisler et al., 2008; Glibert, 2020), 
ballast water transport (Hallegraeff and Gollasch, 2006; Doblin et al., 2007; Smayda, 2007), increases in shellfish aquaculture (Shumway, 2011), climate change (Dale et al., 2006; Moore et al., 2008; Hallegraeff, 2010; O’Neil et al., 2012; Gobler, 2020) and a potential observer effect. In most cases, there is probably not a single cause underlying increases in a HAB's frequency, distribution or toxicity, but rather a complex interplay between these external pressures and the unique physiology of the $\mathrm{HAB}$ species involved which allows it to dominate under certain conditions.

Florida is arguably one of the global epicenters of HABs. Harmful and toxic micro- and macroalgal and cyanobacterial species are found in all of Florida's aquatic environments, from freshwater springs and lakes, to coastal lagoons, estuaries and shelf waters. Three algal toxins, brevetoxin, saxitoxin and domoic acid, have been detected in state waters, resulting in regulatory actions, including shellfish bed closures. One of the most predictable of global HABs, blooms of K. brevis, occur almost annually between August and November in southwest Florida coastal waters (Steidinger, 2009). These blooms are the cause of both neurotoxic shellfish poisoning (NSP) and respiratory irritation (Table 1 ) and are the focus of intensive state monitoring and management (Heil and Steidinger, 2009). Several Florida coastal regions (Indian River Lagoon, Tampa Bay, Charlotte Harbor) are also subject to blooms of the dinoflagellate Pyrodinium bahamense, which can contain saxitoxins that are responsible for both paralytic shellfish poisoning (PSP) and saxitoxin puffer fish poisoning (SPFP) (Landsberg et al., 2006; Abbott et al., 2009). The detection of domoic acid, a toxic, water soluble (Falk et al., 1991) amino acid produced by some species in the diatom genus Pseudo-nitzschia, has resulted in shellfish closures in St. Joseph Bay, Florida for the first time in 2013 and thereafter in 2014 and 2017 (O'Dea et al., 2013; Hubbard et al., 2015, 2017). Cyanobacterial toxins (e.g., microcystins and cylindrospermopsins) have also been detected in Florida fresh (Williams et al., 2007) and marine (Metcalf et al., 2021) waters at concentrations within EPA Drinking Water Health Advisory (HA) levels (United States Environmental Protection Agency, 2015). Other harmful blooms also occur with either uncharacterized toxins (e.g., undescribed Karenia species) or biomass related impacts [e.g., Synechococcus sp. blooms in Florida Bay (Glibert et al., 2009b,c, 2021), and Aureoumbra lagunensis D. A. Stockwell, DeYoe, Hargraves \& P. W. Johnson blooms in the Indian River Lagoon (Gobler et al., 2013; Kang et al., 2015)].

Why are HABs so prevalent in Florida waters? There is no single explanation. Indeed, a number of unique biological, chemical and physical drivers as well as local, regional and global stressors are likely contributing to Florida's HAB prevalence, all of which may be occurring at different temporal and spatial scales. There are numerous freshwater, estuarine and marine potential HAB habitats available. Florida has a long coastline, $2,170 \mathrm{~km}$, second only to Alaska in terms of length. This coastline borders two bodies of water, the Atlantic Ocean and the Gulf of Mexico (GoM) and is easily accessible from within 175 miles of any position within the state. Florida's coastal environments are characterized by widely varying environmental conditions, from marine lagoonal systems with restricted flows and residence times (e.g., the Indian River Lagoon, Florida Bay) to a north flowing river (e.g., St Johns River), to classical river driven estuaries (e.g., Charlotte Harbor and Apalachicola Bay). There are more than 7,800 lakes in Florida (Brenner et al., 1990), including the 4th largest United States natural lake, the 488,000-acre Lake Okeechobee, and numerous freshwater springs. The natural geology of Florida also plays a role in the prevalence of HABs. The sandstone and permeable limestone that characterize Florida karst topography produce a soil characterized by relatively poor nutrient retention (Slomp and Van Cappellen, 2004), which likely contributes to coastal eutrophication. The central west Florida region is also characterized by the Hawthorne Phosphatic Deposits, a natural phosphorus (P) rich geological feature that has been mined continually since the late 19th century (Filippelli, 2011) and results in elevated inorganic and organic $\mathrm{P}$ concentrations in central and southwest Florida coastal waters (Heil et al., 2007). Florida experiences a wide range of climate, from the warm temperate climate of the Panhandle to the Florida Keys, which constitute the northern boundary of the tropics. Florida's weather systems are characterized by two seasons, a wet season and a dry season, which can exacerbate nutrient retention and runoff conditions seasonally. Multiple anthropogenic stressors act on these diverse natural systems on different scales. Florida's human population is constantly increasing, an estimated 845 people move to Florida each day (Office of Economic and Demographic Research, 2021). In south Florida alone, population is projected to increase to over ten million by 2025 and possibly 15 million by 2050 (Obeysekera et al., 2011). Population increases have been accompanied by rapid, often unregulated, residential development. Urban and agricultural development and other associated anthropogenic activities lead to increasing water demands as well as stormwater, wastewater, and agricultural runoff to inland and coastal aquatic systems. In Florida, coastal development has been ongoing since 1912 when the Florida East Coast Railway linked to the Florida Keys, and has been characterized by both recent and historical marine and freshwater eutrophication (Brezonik et al., 1969; Lapointe and Clark, 1992; Havens and James, 2005; Turner et al., 2006; Barile, 2018; Lapointe et al., 2019, 2020). An additional anthropogenic activity in Florida is the management of freshwater flows by both state and federal levels. Lake Okeechobee water levels are managed by the United States Army Corps of Engineers for human safety (Steinman et al., 2002), which in 2018 resulted in the release of Microcystis contaminated lake waters to both the eastern coast via the St. Lucie River and the west coast by the Caloosahatchee River (Krimsky et al., 2018). Indeed, South Florida is currently undergoing one of the largest flow restoration projects in the world, the Comprehensive Everglades Restoration Plan (CERP), which is impacting the amount, timing and distribution of freshwater flows and subsequent nutrient loading to the southern third of the state (Glibert et al., 2021). Overlying these natural features and anthropogenic stressors are the escalating effects of climate change. Florida is considered especially susceptible to the effects of climate change, from warming waters to sea 
TABLE 1 | HAB Syndromes and associated marine HAB species and toxins reported from Florida.

\begin{tabular}{|c|c|c|c|c|c|}
\hline Syndrome & Toxin & Species & Vector & Regulatory level & Mode of action \\
\hline $\begin{array}{l}\text { Neurotoxic shellfish } \\
\text { poisoning (NSP) }\end{array}$ & Brevetoxins & Karenia brevis & Shellfish, water & $\begin{array}{l}\geqq 0.8 \mathrm{mg} / \mathrm{kg} \text { [20 mouse } \\
\text { units }(\mathrm{MU}) / 100 \mathrm{~g}] \\
\text { brevetoxin- } 2 \text { equivalent } \\
\text { or } 5,000 \text { cells/L }\end{array}$ & $\begin{array}{l}\text { Voltage dependent } \mathrm{Na} \\
\text { channel, Site } 5\end{array}$ \\
\hline $\begin{array}{l}\text { Paralytic shellfish } \\
\text { poisoning (PSP) }\end{array}$ & $\begin{array}{l}\text { Saxitoxin and } \\
\text { derivatives }\end{array}$ & $\begin{array}{l}\text { Pyrodinium bahamense } \\
\text { var. bahamense }\end{array}$ & Shellfish & $\begin{array}{l}\geqq 0.8 \mathrm{mg} / \mathrm{kg} \text { saxitoxin } \\
\text { equivalents } \\
(80 \mathrm{mg} / 100 \mathrm{gm})\end{array}$ & $\begin{array}{l}\text { Voltage dependent } \mathrm{Na} \\
\text { channel, Site } 1\end{array}$ \\
\hline $\begin{array}{l}\text { Amnesic shellfish } \\
\text { poisoning (ASP) }\end{array}$ & $\begin{array}{l}\text { Domoic acid and } \\
\text { isomers }\end{array}$ & Psuedo-nitzschia spp. & $\begin{array}{l}\text { Fish, shellfish, } \\
\text { crustaceans }\end{array}$ & $\begin{array}{l}\geqq 20 \mathrm{mg} / \mathrm{kg} \text { domoic } \\
\text { acid }\end{array}$ & Glutamate receptors \\
\hline $\begin{array}{l}\text { Saxitoxin puffer fish } \\
\text { poisoning (SPFP) }\end{array}$ & $\begin{array}{l}\text { Saxitoxin and } \\
\text { derivatives }\end{array}$ & $\begin{array}{l}\text { Pyrodinium bahamense } \\
\text { var. bahamense }\end{array}$ & Fish & $\begin{array}{l}\geqq 0.8 \mathrm{mg} / \mathrm{kg} \text { saxitoxin } \\
\text { equivalents } \\
\text { (80 mg/100 gm) }\end{array}$ & $\begin{array}{l}\text { Voltage dependent } \mathrm{Na} \\
\text { channel, Site } 1\end{array}$ \\
\hline $\begin{array}{l}\text { Ciguatera fish } \\
\text { poisoning (CFP) }\end{array}$ & Ciguatoxins & Gambierdiscus toxicus & Reef fish & $\begin{array}{l}\text { Caribbean ciguatoxins: } \\
>0.1 \mathrm{mg} / \mathrm{kg} \text { Caribbean } \\
\text { Ciguatoxins-1 } \\
(\mathrm{C}-\mathrm{CTX}-1) \text { equivalents }\end{array}$ & $\begin{array}{l}\text { Voltage dependent } \mathrm{Na} \\
\text { channel, Site } 5\end{array}$ \\
\hline $\begin{array}{l}\text { Diarrheic shellfish } \\
\text { poisoning (DSP) }\end{array}$ & $\begin{array}{l}\text { Okadaic acid and } \\
\text { derivatives }\end{array}$ & $\begin{array}{l}\text { Dinophysis spp. } \\
\text { Prorocentrum spp. }\end{array}$ & Shellfish & $\begin{array}{l}\geqq 0.16 \mathrm{mg} / \mathrm{kg} \text { okadaic } \\
\text { acid equivalents }\end{array}$ & $\begin{array}{l}\text { Serine/threonine } \\
\text { protein phosphatases }\end{array}$ \\
\hline
\end{tabular}

level rise to increasing storm intensities (Obeysekera et al., 2011; Reece et al., 2013).

Harmful Algal Blooms and their associated toxins thus represent significant risks to human and environmental health as well as local and state economies within Florida in ways that are unique to the state. The goal of this review is to provide an overview of major $\mathrm{HAB}$ species of specific concern in Florida waters, including a brief review of the ecology and associated risks of these species, and an evaluation of the potential impacts of climate change on these species and their associated risks in the future. As such, it is structured to include an overview of the human, environmental and economic risks associated with HABs in Florida, followed by a review of the different HAB groups and major species, then a discussion of the potential impacts of climate change on these $\mathrm{HAB}$ species and future challenges posed for $\mathrm{HAB}$ research and management by these impacts. How climate change is impacting HABs now and in the future in Florida represents a major challenge for local, state and federal HAB researchers and managers. By highlighting the ecology and impacts of the major HABs and the potential impacts of the local (e.g., water quality), regional and global stressors (e.g., climate change) on Florida's HABs, our hope is to provide potential direction on relevant future research efforts to reduce these risks.

\section{HAB ASSOCIATED RISKS}

The impacts of HABs fall into three categories: harmful effects upon human health, detrimental environmental impacts including impacts to aquatic biota, and economic losses to a range of sectors and stakeholders. Of these three, the assessment of risks associated with HABS has focused primarily on human health (Hitzfeld et al., 2000; Carmichael, 2001; Van Dolah et al., 2001; Krahl, 2009; Cheung et al., 2013; Ibelings et al., 2014; Janssen, 2019). These effects can be significant, even life threatening, depending on the particular HAB species, the toxin involved and the route of exposure (Berdalet et al., 2016). Global estimates of $\mathrm{HAB}$ related human intoxification incidences range from 6,000 per year (Hallegraeff, 1993; Van Dolah, 2000) to more than 500,000 per year (Quod and Turquet, 1996).

These routes of $\mathrm{HAB}$ exposure to humans vary with the species involved, the toxin, and even the location, but all fall into one of three exposure routes: (1) ingestion of contaminated fish, shellfish or drinking water, (2) exposure to aerosolized HAB toxins, or (3) dermal contact with a HAB. All of the human health syndromes associated with HAB exposure in Florida (Table 1) result from one of these three routes. Regulatory effects have primarily focused on the ingestion route, particularly that of shellfish, which through feeding efforts can act to biomagnify toxins in their tissues. The three toxins that are the primary focus of HAB monitoring in Florida, brevetoxin, saxitoxin, and domoic acid, all have regulatory levels established by the FDA [FDA and EPA Safety Levels in Regulations and Guidance, A5 - 12 (March 2020)]. This is because the risks associated with ingestion of these toxins are most closely defined by the formal framework for Risk Assessment outlined by the National Research Council in 1983 (National Research Council [NRC], 1983), which include 4 sequential steps: (1) identification of the hazard, (2) a doseresponse assessment of the hazard, (3) exposure assessment of the hazard, and (4) a risk characterization of human exposure. Brevetoxin, saxitoxin and domoic acid have been identified and chemically characterized and the dose required for impacts has been estimated from natural events and epidemiological studies. Exposure assessment establishes the extent and routes of potential toxin exposures, namely ingestion, inhalation or dermal contact. Effect risk characterization merges the last 2 steps to determine the probability of toxin exposure in sufficiently high concentrations to have a clinical effect (Van Dolah et al., 2001; Krahl, 2009). This is most easily assessed for ingestion of identified toxins. For the majority of HAB species, however, the information required to assess risk, from identification of 
the toxin and its chemical structure to determining potential biomarkers of exposure is poorly understood or unknown. Thus, the assessment of human risk associated with most HABs is in its early stages, especially for inhalation and dermal contact exposure routes.

Health risk assessment of HABS is further hampered by many additional factors, including a lack of toxin identification for some species as well as lack of knowledge of toxin transformations in the environment, lack of biomarkers of exposure, and even the dynamic physical nature of blooms which makes both predicting and determining exposure difficult. Determination of the human health impacts of HAB toxin exposure has largely focused on acute impacts of limited exposure. In Florida, there is a large emphasis on brevetoxins associated with $K$. brevis blooms due to frequency and the number of individuals impacted (e.g., Kirkpatrick et al., 2004; Fleming et al., 2011). For many HAB routes of exposure, the health effects of chronic exposure are unknown and require further research. For example, the impacts of shortterm inhalation of aerosolized brevetoxins from $K$. brevis blooms is established (Backer et al., 2003; Fleming et al., 2007, see Fleming et al., 2011 for review). Blooms of K. brevis may persist in southwest coastal waters for periods of up to 30 months (Steidinger, 2009) and the impacts of this longer term exposure of aerosolized brevetoxins are unknown. Even less is known about both the acute and chronic impacts of exposure to aerosolized cyanotoxins. Increases in the frequency of blooms of the toxic cyanobacteria Microcystis in Lake Okeechobee (Havens and Steinman, 2015; Havens et al., 2019), especially in 2018 when a large Microcystis bloom in the Lake was transported to the east and west coasts via release through the St. Lucie and Caloosahatchee Rivers, combined with the detection of microcystin in nasal swabs from people exposed to this Microcystis bloom (Schaefer et al., 2020), suggests that this toxin route merits further investigation.

The environmental impacts of Florida HABs are diverse and significant. Reviews of the impacts of HABs on biota and the environment are provided by Landsberg (2002); Landsberg et al. (2009), Basti et al. (2018); Shumway et al. (2018), Zohdi and Abbaspour (2019), and Brown et al. (2020). Impacts range from direct, acute impacts of toxins on freshwater and marine biota (e.g., fish, marine mammal and sea turtle mortalities) to indirect effects through food web transfer of toxins (Landsberg, 2002; Landsberg et al., 2009) and/or bloom-associated anoxia such as occurred with larger K. brevis blooms on the central west Florida shelf in 1974 (Smith, 1975, 1979) and 2005 (Hu et al., 2006). The HAB species and toxins involved are especially important in predicting environmental impacts associated with blooms. In many cases, e.g., $K$. brevis blooms, acute bloom impacts are well documented, while routes of toxin transfer are still being elucidated (Abraham et al., 2021). In other cases, e.g., other Karenia species, these impacts are yet to be determined. Sublethal impacts, especially during extended blooms, are poorly understood and are dependent on our identification and understanding of the toxin(s) involved, including their structures and modes of action.

Harmful Algal Blooms are costly. Global estimates of HAB impacts on human health alone are over $\$ 4$ billion dollars per year (United Nations Environment Programme, Joint Group of Experts on the Scientific Aspects of Marine Environmental Protection, 2001, references in Berdalet et al., 2016). Estimates of HAB related losses in the United States have been steadily increasing over time. Anderson et al. (2000) and Hoagland et al. (2002) put annual losses related to HABs in the United States at \$20 million dollars at the start of the 21st century. These estimates have increased from $\$ 50$ to $\$ 82$ million dollars annually (Hoagland and Scatasta, 2006; Anderson et al., 2012). These economic costs generally are attributed to losses in four sectors: public health, commercial fisheries, tourism and recreation, and $\mathrm{HAB}$ monitoring and management. They include economic losses from relevant markets (e.g., seafood, labor, and coastal tourism), costs associated with the $\mathrm{HAB}$ and its impacts (e.g., public health) and the cost of mitigating these impacts (e.g., costs of cleaning dead fish from beaches, monitoring) (Hoagland and Scatasta, 2006). Losses attributed to each of these sectors will vary greatly with the $\mathrm{HAB}$ involved and its impacts.

Quantifying the economic risks of HABs and HAB associated losses has proven to be challenging. One difficulty in evaluating $\mathrm{HAB}$ economic risks lies in their differences from other natural hazards. HABs differ from other large natural hazards such as hurricanes or earthquakes in that their impacts are not necessarily immediate (Bechard, 2020b) or restricted to a limited area. HABs can last for an extended period. The longest duration K. brevis bloom occurred for 30 months from 1994 to 1997 (FWRI HAB Historical Database) while blooms of Synechococcus have persisted intermittently in Florida Bay since 1999 for periods of up to 3 years (Glibert et al., 2009b,c). HABs can also impact large regions: the 1986-1987 K. brevis bloom impacted most of the coastline of Florida and the eastern seaboard as far north as North Carolina (Tester et al., 1991; Tester and Steidinger, 1997). Economic impact estimates rarely account for economic 'halo' effects, which are collateral losses resulting from human perceptions related to HABs, such as consumer avoidance of goods (e.g., shellfish) perceived as tainted by HAB toxins (Jensen, 1975; Kuhar et al., 2009; Adams et al., 2018). This can be a significant risk for sectors such as Florida's tourism industry, which relies upon images of pristine beaches to draw people globally and are heavily impacted by public perception (Kuhar et al., 2009; Cahyanto and Liu-Lastres, 2020). This social amplification of risk, which may potentially be intensified by the media (Li et al., 2015), is an extensive problem with Florida red tide specifically (Hoagland et al., 2020).

Within both the United States and Florida, the scientific focus of assessing economic losses related to HABs has been primarily on K. brevis blooms. Adams et al. (2018) in their review of existing literature, research methods, data, and information gaps of current $\mathrm{HAB}$-economic research, point out that 18 of the 36 relevant $\mathrm{HAB}$ economic papers focus on $K$. brevis blooms in Florida. This is not unexpected as K. brevis blooms reoccur annually, generally impact larger areas of the state relative to other HABs and affect the greatest number of people and businesses. Initial estimates of economic losses associated with these blooms range from $\$ 20$ million dollars for a 1971 bloom in southwest Florida (Habas and Gilbert, 1974) to $\$ 18.45$ million dollars for a 2000 Texas K. brevis bloom (Evans and Jones, 2001). Interestingly, Habas and Gilbert (1974) suggest that their estimate 
is likely a significant underestimate of true bloom costs due to an array of costs that were masked by substantial economic growth during the bloom period. These studies focused primarily on losses within the fisheries and tourism sectors. It is now understood that the economic impacts of these blooms, especially the infrequent, longer duration, high impact $K$. brevis blooms such as occurred in 2017-2019, are complex, diverse, and longlasting. Direct economic losses via negatively impacted businesses are predominantly marine (e.g., fisheries and aquatic dependent businesses) or tourism related, and costs to local governments associated with bloom mitigation costs. But significant losses are also associated with the costs of bloom associated human health care as well as impacts on property values and government revenues (Adams et al., 2018).

Other bloom associated economic losses include losses to the fishery (both wild harvest and aquaculture) and seafood sectors. Anderson et al. (2000) estimated that 37\% of HAB related economic losses were attributable to commercial fisheries in the United States, which Hoagland and Scatasta (2006) increased to $48 \%$. These are likely underestimates as they account primarily for direct economic losses and do not include the halo effect (Hoagland and Scatasta, 2006). Béchard (2020a) found that in one Florida County alone, taxable sales receipts for the fishery and seafood sectors experienced a \$20,000 monthly loss, or $4.8 \%$ below normal, when a $K$. brevis bloom was present. These estimates also represent 'acute' impacts during the time of the bloom, generally when extensive fish kills occur. Blooms of $K$. brevis have recently been shown to impact fish community diversity for extended periods (Gannon et al., 2009; DiLeone and Ainsworth, 2019), with severe blooms such as occurred in 2005 and 2018 resulting in declines in annual recruitment of commercially important species such juvenile spotted seatrout (Cynoscion nebulosus), sand seatrout (Cynoscion arenarius), and red drum (Sciaenops ocellatus) (Flaherty and Landsberg, 2011), and multiyear closures of some commercial fisheries that are especially sensitive to brevetoxin impacts [e.g., snook (Centropomus undecimalis)], red drum and sea trout (Gillis, Feb 19, 2020).

Florida's economy is heavily dependent upon tourism revenue. In 2017-2018 alone, visitors to Florida accounted for from \$1.84 billion dollars economic impact (Visit Sarasota County, 2019) to $\$ 22$ billion dollars in beach related tourism. Much of the attractiveness of Florida to tourists results from its environment, including warm weather and a long coastline with beautiful beaches and a healthy ocean. Any threat to Florida's environment is a threat to its tourism industry. As such, the economic losses due to tourism from HABs can be considerable (Habas and Gilbert, 1974; Adams et al., 2002; Larkin and Adams, 2007; Morgan et al., 2009, 2010). Larkin and Adams (2007) report reductions in monthly revenue of restaurants and lodging of \$2.8 and \$3.7 million dollars, respectively (29 and 35\% declines, respectively) in Ft. Walton Beach and Destin areas of the Florida Panhandle for 1995-1997 when a K. brevis bloom was present. Three beachfront restaurants reported reductions in revenue due to red tide from $\$ 646$ to $\$ 3,734$ (13.7-51.3\% on average) per day (Morgan et al., 2009). Adams et al. (2000) was unable to demonstrate a negative effect upon beach attendance during a red tide but suggested this may reflect inadequate data resolution or the selection of alternative entertainment by business patrons. Bechard (2019) reported a 15\% decrease in sales in Sarasota County during persistent blooms, while the food and restaurant sector losses averaged $1.75 \%$. Similar reductions in adjacent, unimpacted counties were not evident. Further research over an extended 6 county area from Pinellas to Collier Counties in southwest Florida (Bechard, 2020d) reported that each additional day of red tide per month in excess of 17 days drove lodging sales down $1-2 \%$ and restaurant sales down $0.5-1 \%$. While these results suggest that economic impacts may be localized to the areas of the bloom, they also demonstrate that these impacts can be significant.

Health care costs during $K$. brevis blooms are related to digestive, gastrointestinal and respiratory impacts (Hoagland et al., 2014; Patel et al., 2020). Kirkpatrick et al. (2006) utilized hospital records to compare the number of patients admitted with respiratory disease during red tide periods with non-bloom periods and found a significant increase in the ER admissions for respiratory diseases during the 2001 red tide compared to the 2002 non-red tide period, with elevated rates among individuals living within 1.6 miles of the shore. A 40\% increase in gastrointestinal diagnoses and admissions were also found (Kirkpatrick et al., 2010). Hoagland et al. (2009) estimated the costs of respiratory illness associated with $K$. brevis blooms in Sarasota County alone to be between $\$ 0.5$ and $\$ 4$ million depending on bloom severity. Increased health costs were associated with older cohorts ( $>55$ years of age) in 6 southwest Florida counties and ranged from $\$ 60,000$ to $\$ 700,000$ annually depending on bloom severity (Hoagland et al., 2014). The authors suggest that capitalized costs of future $K$. brevis related illnesses could be up to $\$ 24$ million dollars.

Although they reoccur each year, Florida red tides vary greatly in their severity, duration, impacts and spatial extent. The 20172019 K. brevis bloom was especially severe, lasting for 17 months and impacting most of Florida's 23 Gulf counties. This bloom has provided an opportunity to estimate the higher end economic impacts possible with a severe K. brevis bloom. A Gulf of Mexico Alliance Report (The Balmoral Group., 2020) documented the total losses attributable to this bloom in Florida Gulf counties of $\$ 1$ billion dollars, with an additional tax revenue decline of $\$ 178$ million dollars. The tourism sector had by far the greatest loss, \$455 million dollars in direct loss and a \$113 million dollar loss in tax revenue, followed by property values ( $\$ 343$ and $\$ 32$ million dollars, respectively) then boat sales ( $\$ 55$ and $\$ 21$ million dollars, respectively) and recreational and commercial fisheries. Economic losses attributable to human health impacts were not figured into these losses, nor were losses attributed to marine mammal strandings (\$198 million dollars, The Balmoral Group., 2020). Bechard (2019) reported monthly losses to lodging and restaurant sectors to be between 1 and $15 \%$ and 0.5 and $1.7 \%$, respectively, during the 2006 and 2018 blooms in counties where red tide was present. Property values within 1 mile of the coast sold for up to $30 \%$ less compared with similar homes in areas with no red tide, and (Bechard, 2021; Bechard, 2020c) reported that during a 16 year period that included the 2018 bloom, property values decreased by $10 \%$ during the bloom with an additional 
decline of $1-2 \%$ for each additional bloom month, with steeper decreases experienced by waterfront homes.

Little is known of the economic costs associated with HABs other than K. brevis in Florida. Hoagland and Scatasta (2006) attributed public health costs of $\$ 250,000$ and $\$ 525,000$ per year for reported and unreported cases of ciguatera poisoning, respectively, in Florida from 1987 to 1992. Todd (1985) quantified the economic losses resulting from ciguatera poisoning (medical costs and lost labor) at $\$ 2.7$ million dollars per year, suggesting that Florida's costs are potentially greater than $\$ 775,00$ per year if lost labor costs are factored in. Given that significant revenue losses associated with ciguatera continue to exist for fish dealers who produce grouper on Florida's east coast (Raizin and Meaburn, 1988), these estimates are likely low. In the south Pacific region where it is endemic, ciguatera poisoning has been shown to result in increases in health care costs (Lewis, 1986), labor productivity losses (Bagnis et al., 1992) and tourism (Lewis, 1992) and fish sale (Yeeting, 2009) losses ranging from $\$ 1.1$ million (Bagnis et al., 1992) to \$22 million dollars annually (Hoagland et al., 2002). Other HABs, such as Synechococcus spp. blooms in Florida Bay, and cyanobacterial blooms statewide, undoubtedly have significant negative impacts on both tourism and fisheries but economic losses have not yet been quantified.

Management efforts are necessary to prevent or lessen economic, environmental and human health impacts of HABs and these generally focus on HAB mitigation. Mitigation of HABs is comprised of 3 categories: prevention of HABs, control of HABs and associated toxins and mitigation of the impacts of HABs (Boesch et al., 1996; CENR, 2000; Sengco, 2009a,b). Prevention focuses on strategies to prevent bloom occurrence or to limit their scope. These include limiting nutrient supply to blooms, management of the physical conditions that play a role in initiation and preventing HAB introductions to new areas (Anderson, 2004) and requires critical knowledge of the biological, chemical and physical factors contributing to bloom initiation which may not be known. Control strategies focus on efforts to destroy or remove both the HAB cells and associated toxins and include both application of chemical controls [e.g., copper sulfate (Sengco, 2009b) and removal technologies (Hallegraeff et al., 2017)]. Mitigation has received the greatest scientific and funding focus with both HABs in general and with Florida HABs, especially K. brevis blooms, and includes efforts to limit the impact of blooms through monitoring, education and communication outreach (Kleindinst and Anderson, 2004; Fleming et al., 2007; Kirkpatrick et al., 2008; Nierenberg et al., 2011) as well as development and application of HAB forecasting models (Walsh et al., 2001; Stumpf et al., 2003, 2009; McGillicuddy, 2010; Kavanaugh et al., 2013). For HABs in Florida, monitoring related technologies are rapidly advancing and being applied, from molecular and optical detection methods (e.g., HABscope for K. brevis monitoring, Hardison et al., 2019) to improved impact predictions (e.g., NOAA respiratory predictions, Stumpf, 2008).

Florida has perhaps the earliest attempt to mitigate the risks associated with a marine $\mathrm{HAB}$ when in 1947, during one of the most severe $\mathrm{K}$. brevis blooms on record in southwest Florida, Florida Senator Claude Pepper requested that the
Navy send planes to bomb the dead fish and Rear Admiral Davidson telegraphed Senator Pepper that this was 'inadvisable as likely to disperse present concentration and involve additional beach communities' (Sarasota Herald Tribune, 1947). Subsequent collaborative state and federal efforts focused on the use of copper sulfate to control K. brevis blooms in the 1950's (see Sengco, $2009 \mathrm{~b}$ for review) with additional research on potential algicidal control (Mayali and Doucette, 2002; Roth et al., 2007, 2008; Lin et al., 2016; Kinley-Baird et al., 2021) and clay flocculation thereafter (Sengco et al., 2001; Lewis et al., 2003; Pierce et al., 2004). At the state level, Florida's recent reinvigoration of the $\mathrm{HAB}$ and Red Tide State Task Forces has led to an increasing scientific, management and public focus on HAB mitigation research and application within the state. Florida's Red Tide Mitigation and New Technology Initiative Program (2019-2025) also represents a substantial unique state effort to fund the development of new technology and mitigation research and application efforts related to $K$. brevis blooms.

\section{FLORIDA HABs}

The state of Florida routinely monitors for more than 75 HAB species in freshwater to marine environments. While the agencies directly involved are primarily Florida Fish and Wildlife Conservation Commission's Fish and Wildlife Research Institute for estuarine and marine HABs and the Florida Department of Environmental Protection for freshwater HABS, many local municipalities and counties, especially those in southwest Florida that experience annual K. brevis blooms, maintain some monitoring and management capabilities, especially with beach cleanups, or directly collaborate with the state agencies. The following sections summarize the main Florida HAB species of concern for human, environment and economic health in the state. It is by no means an exhaustive list, but is meant to provide a summary of the relevant state of knowledge of each HAB species to allow evaluation of the potential risks associated with each, especially in light of Florida's ongoing demographic and environmental challenges.

\section{Dinoflagellate HAB Species Karenia brevis (Florida Red Tide)}

Blooms of the toxic dinoflagellate Karenia brevis represent perhaps the most widely known and potentially greatest $\mathrm{HAB}$ threat to the state. Known colloquially as Florida Red Tide, these blooms reoccur annually in southwest Florida, impact the greatest number of people and biota both directly and indirectly, and have the largest, most widespread economic impacts of all Florida HABs (Heil and Steidinger, 2009; Steidinger, 2009). Considered among the most predictable of global HABs, K. brevis (formerly Gymnodinium breve, Ptychodiscus brevis, and Gymnodinium brevis) blooms have a long and extensive history which predates the taxonomic identification and description of the causative dinoflagellate after one of the most destructive blooms on record in 1947 (Davis, 1948). Galtsoff (1948) reported of the 1947 bloom that 'All the beaches in the Fort Myers area became littered with dead (fish) bodies which were reported to 
accumulate at a rate of more than 100 pounds per linear foot of shore line.' But the existence of K. brevis blooms is known to predate this 1947 bloom based on records of its unique human symptomology (Steidinger, 2009). Respiratory irritation, which occurs in humans exposed to aerosolized brevetoxins at or near bloom impacted beaches or in the vicinity of blooms offshore, was first noted in 1917 (Taylor, 1917). The unique human symptomology of Neurotoxic Shellfish Poisoning (NSP), the syndrome associated with consumption of shellfish exposed to $K$. brevis which have concentrated brevetoxins, was noted in 1880 in Tampa Bay in association with local oyster saloons (Steidinger, 2009). K. brevis bloom history likely extends much further back in GoM history based on anecdotal reports and ship logs which describe extensive fish kills in the region (Steidinger, 2009).

The more recent record of $K$. brevis blooms has received much public attention. With the onset of formal state red tide monitoring in the 1980's and the establishment of an extensive monitoring network, the recent bloom record is extensive, with well documented blooms of varying extent, duration and impacts occurring almost annually. The state HAB Historical Database of Florida currently includes $>85,000$ georeferenced entries for K. brevis concentrations dating from 1952 to current times, and was originally compiled in 2000 from more than 70 different entities and sources (e.g., academia, non-profit, local state, and federal agencies) (Haverkamp et al., 2004). This database reflects the temporal, spatial and depth biases associated with these disparate data sources and the event response nature of $K$. brevis sampling prior to formal monitoring efforts in the 1990's. Although Brand and Compton (2007) have interpreted the database as supporting an increasing frequency of $K$. brevis blooms in southwest Florida, statistical analysis of the database for long term trends remains problematic (Heil et al., 2014a). Walsh et al. (2006) examined the long term records of K. brevis blooms off both Texas and southwest Florida in conjunction with available nutrient data and concluded that while increasing incidences of blooms off Texas were likely related to nutrient discharges from the Mississippi River, those off Florida were not directly related to nearshore nutrient inputs. Regardless of prior bloom history, however, coastal development continues, as does ongoing immigration to the state and the eutrophication of Florida's freshwater, estuarine and coastal waters. The net effect of this is that more Florida residents and visitors are experiencing and being exposed to Florida Red Tide and its environmental and economic impacts over time than ever before.

Karenia brevis cells are a natural feature of the GoM and cells are found year round throughout the GoM at background concentrations of 1,000 cells $\mathrm{L}^{-1}$ or less (Geesey and Tester, 1993). Although blooms occur throughout Florida coastal waters, including the Panhandle and the east coast, blooms in these regions are preceded by established blooms in southwest Florida waters in the region between Tarpon Springs and Naples (Heil and Steidinger, 2009; Steidinger, 2009). In this southwest region blooms occur almost annually, initiating in late summer to early fall and lasting anywhere from 3 to 4 months to greater than 30 months in 1994-1997.

To understand why blooms are most common in southwest Florida, there is a need to understand the physical and chemical oceanography of this region as well as the coastal morphometry. Vargo (2009) reviewed the 24 theories proposed to explain $K$. brevis blooms from the 1880's to 2009. Many early red tide studies attempted to associate coastal blooms with local nutrient, weather or physical conditions. Ingle and Martin (1971) attempted to correlate bloom occurrence with an Iron-index of riverine conditions while Slobodkin (1953) related blooms to low salinity, coastal water masses. Even in the 1950's controversy existed surrounding the role of local nutrient inputs such as the Caloosahatchee River on blooms, with Murdock (1954) arguing that 'The continuing high rate of water release from the Caloosahatchee River may be a contributing cause to Red Tide Outbreaks,' while Graham et al. (1954) pointed out that 'Neither the rivers, nor the bottom of the Gulf, nor the deep water of the Gulf can be held as a source of phosphorus sufficient to increase the concentration in the body of coastal water to the values which are found in red tide samples.' None of these studies successfully explained how an organism characterized by relatively slow growth rates, 0.2-0.3 divisions day ${ }^{-1}$ (Vargo, 2009), was able to dominate phytoplankton biomass in these coastal blooms so rapidly until Steidinger (1975) recognized and documented the four stages of $K$. brevis blooms: initiation, growth, maintenance and termination. Blooms initiate $18-74 \mathrm{~km}$ offshore in $12-$ $37 \mathrm{~m}$ depths on the mid-shelf of the southwest Florida coast, most often between Tarpon Springs and Naples (Steidinger, 1973). While offshore initiation has been documented in 1966, 1976, 1979, 1985, 1998, and 2008 (Steidinger, 2009; Heil et al., 2014a), identifying this stage remains problematic due to the low concentrations of subsurface $K$. brevis cells which are difficult to detect, either remotely or with autonomous technology, and the large potential offshore geographical area over which the blooms potentially initiate. At this stage, physical drivers are crucial to bloom development. Offshore upwelling related to Loop Current intrusion plays an important role in bloom initiation, with some upwelling required for initiation (Liu et al., 2012; Weisberg et al., 2014). Too much upwelling, however, delivers sufficient upwelled $\mathrm{NO}_{3}{ }^{-}$to the shelf bottom waters to favor diatom development and impede K. brevis growth (Heil et al., 2001; Weisberg et al., 2016). Cells then grow slowly and are transported cross-shelf via the bottom Ekman layer (Weisberg et al., 2009, 2016), driven by wind-driven and upwelling-related transport. Winds, frontal systems and longshore currents act to concentrate increasingly dense K. brevis populations shoreward (Tester and Steidinger, 1997; Vargo et al., 2001, 2004; Weisberg and He, 2003; Janowitz and Kamykowski, 2006) where the blooms may persist for months to years (Steidinger, 2009). Weisberg et al. (2019) demonstrated that the dramatic increase in cell counts off the Pinellas County coastline in September 2018 which contributed to the unusually severe 2017-2019 K. brevis bloom was shown to be due to advection from the offshore formative region (Weisberg et al., 2019). This 2018 southwest Florida bloom was subsequently advected to the Florida Panhandle and east coast in a similar manner later in the bloom as has been demonstrated for K. brevis blooms in 2005 (Carlson and Clarke, 2009).

The nutrient sources that sustain $K$. brevis blooms as well as the nutrient physiology of K. brevis are complex. Trichodesmium blooms have long been observed to immediately precede and 
often co-occur with $K$. brevis blooms on the west Florida shelf and a relationship between the two species was suggested (Chew, 1955; Steidinger, 1973; Taylor and Pollingher, 1987). Walsh and Steidinger (2001) documented their co-occurrence over a 41 year period on the west Florida shelf from 1957 to 1998 and hypothesized that these two species were nutritionally linked through the transport and deposition of Fe-rich Aeolian dust from north Africa, which supplied the Fe required for Trichodesmium $\mathrm{N}_{2}$ fixation. Lenes et al. (2001) documented increases in $\mathrm{Fe}$ concentrations in surface water after dust deposition, with subsequent increases in DON and K. brevis concentrations. Trichodesmium can release up to $50 \%$ of fixed $\mathrm{N}$ to the environment as $\mathrm{NH}_{4}{ }^{+}$and dissolved organic $\mathrm{N}$ (Capone et al., 1994; Glibert and Bronk, 1994). This N, in turn, is taken up by K. brevis (e.g., Lenes et al., 2001; Mulholland et al., 2002, 2006, 2014; Sipler et al., 2013; Heil et al., 2014c; Killberg-Thoreson et al., 2014).

As blooms grow and are transported nearshore, the nutrient sources available to cells increase and can include (1) benthic nutrient flux (Dixon et al., 2014a); (2) photochemical nutrient production (Bronk et al., 2014); (3) nitrification (Bronk et al., 2014), (4) zooplankton grazing (Walsh and O'Neil, 2014); and (5) nearshore coastal sources from estuarine and river runoff and inputs (Vargo et al., 2008; Dixon et al., 2014b; Heil et al., 2014c). As bloom concentrations increase nearshore to concentrations $>10^{6}$ cells $\mathrm{L}^{-1}$ (Heil and Steidinger, 2009), nutrient regeneration from dead fish also can play an increasingly important role (Walsh et al., 2009; Killberg-Thoreson et al., 2014; Heil et al., 2014c). The exact sources which contribute to bloom maintenance nearshore depends upon bloom latitude as well as distance offshore and bloom age (Heil et al., 2014a). Nutrient stoichiometry calculations (Vargo et al., 2008; Heil et al., 2014c) have shown that sufficient nutrients are present to support moderately sized, nearshore $K$. brevis blooms, during average estuarine flow years: combined estuarine sources contribute up to 17 and $69 \%$ of the $\mathrm{N}$ and $\mathrm{P}$ needs of these blooms, although only $\mathrm{N}_{2}$ fixation and release and decay of seasonal Trichodesmium bloom biomass are sufficient to provide for the $\mathrm{N}$ needs of larger blooms (Lenes and Heil, 2010).

The factors that control $K$. brevis bloom expansion and termination are less understood. Favorable physical and sufficient nutrient sources are required to expand blooms and increase their biomass. Potential nutrient sources that are important to these bloom stages may include additional nutrient sources derived from excessive freshwater inputs linked to hurricanes or water management practices. Hu et al. (2006) suggested that a series of hurricane inputs in 2004 contributed to the severity of the $2005 \mathrm{~K}$. brevis bloom. The severe 2017-2019 bloom was preceded by intense flooding and runoff following Hurricane Irma in fall of 2017, along with an extremely wet season in 2018 which resulted in management decisions to release high volumes of nutrient-laden Lake Okeechobee water through the Caloosahatchee and St. Lucie Rivers. Both

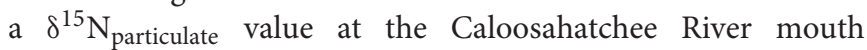
(Yentsch et al., 2008) and statistical tests with convergent cross mapping and upriver $\mathrm{N}$ concentrations (Medina et al., 2020) suggest that $K$. brevis blooms at the Caloosahatchee River mouth can utilize some fraction of inland agricultural nutrient sources. Uhlenbrock (2009) examined nutrient concentrations within the river during 2005 releases and concluded that nutrient loading rates into San Carlos Bay from the River provided sufficient DON and DIN to support the $K$. brevis bloom at the river mouth during the study. Note that these blooms often extend well to the south and north of the river mouth, and when the larger bloom areas are taken into account, there are insufficient nutrient inputs from the Caloosahatchee River to support the larger blooms. Heil et al. (2014c) utilized nutrient stoichiometry to examine the potential role of Caloosahatchee River $\mathrm{N}$ and $\mathrm{P}$ loading rates, in comparison with other known nutrient sources for blooms, to support small, medium and large estuarine, coastal and offshore $K$. brevis blooms. River inputs were significant for small estuarine blooms at the river mouth but decreased significantly for larger estuarine blooms and small coastal blooms. These results suggest that the input of river $\mathrm{N}$ and $\mathrm{P}$, while significant for smaller K. brevis blooms at or near the river mouth, are insufficient to account for blooms of higher concentrations or larger spatial extent.

The mechanisms controlling bloom termination likely include physical, chemical and biological processes. Blooms may be transported offshore, entrained in offshore fronts, and transported out of the area (Steidinger, 2009). Blooms frequently transport south to the Ten Thousand Island area in southwest Florida, then migrate either east through the Florida Straits and up the east coast (15 times from 1972 to 2018) or westward into the central Gulf. Chemical and biological factors may include nutrient impoverishment as well as bacterial and viral processes. Lenes et al. (2013), in a bloom simulation which examined factors important in $K$. brevis bloom termination, reported a modeling efficiency of 0.68 when a bacterial lysis term was introduced to nutrient limited K. brevis populations. Algicidal bacteria (Mayali and Doucette, 2002; Roth et al., 2007, 2008) as well as viruses (Paul et al., 2002) have been documented for $K$. brevis, but their role in bloom dynamics and bloom termination is unknown.

Vargo (2009) summarized the physiological and ecological characteristics of $K$. brevis that contributes to its dominance of coastal phytoplankton communities during blooms. Cell motility may play a role, as K. brevis is capable of complex physiological regulation of its position in the water column (Heil, 1986; Kamykowski et al., 1998; Sinclair and Kamykowski, 2008; Heil et al., 2014b) as well as an effective photoadaptive strategy (Shanley, 1985; Shanley and Vargo, 1993; Millie et al., 1997; Evens et al., 2001; Evens and Leblond, 2004). Karenia brevis may gain a competitive advantage through the production of allelopathic substances (Kubanek et al., 2005; Prince et al., 2008, 2010; Poulson-Ellestad et al., 2014; Poulin et al., 2018) and a reduction in grazing losses due to the negative impacts of brevetoxins on higher trophic levels (Huntley et al., 1986; Turner and Tester, 1989, 1997; Lester, 2005; Waggett et al., 2012; Walsh and O'Neil, 2014). Not only is K. brevis able to utilize a variety of different nutrient sources, but nutrient physiology of $K$. brevis may also play a significant role in the dominance of these blooms. Recent evidence suggests that 
K. brevis may also be capable of mixotrophic uptake of the picocyanobacteria Synechococcus (Jeong et al., 2005; Glibert et al., 2009a; Procise, 2012). Growth of marine picocyanobacteria in southwest Florida coastal waters is correlated with urea (Heil et al., 2007), which has been shown to increase with both large scale hurricane related inputs (Heil et al., 2007) and localized episodic, wind driven inputs (Ivey et al., 2020). Nutrient stoichiometry also may play a further role in K. brevis blooms as Walsh et al. (2006) suggested that the generally low DIN:DIP ratios that characterize southwest Florida rivers $(<4)$ favor $K$. brevis as they select against diatoms which typically utilize oxidized $\mathrm{N}$ forms.

Human health impacts of $K$. brevis blooms are attributed to ingestion of brevetoxin contaminated shellfish (NSP), exposure to brevetoxin laden aerosols (see Kirkpatrick et al., 2004; Fleming et al., 2005, 2011 for reviews). Cases of NSP are now relatively rare due to effective monitoring of blooms and commercial shellfish beds within the state (Heil, 2009), but they do sometimes occur, especially when non-English speaking residents or tourists illegally harvest and consume contaminated shellfish. Respiratory irritation results from exposure to aerosolized brevetoxins contained within sea spray generated from the bloom (Pierce et al., 2003, 2005). Cells break apart at the water surface or in the surf zone, and dissolved brevetoxins are incorporated into sea spray. Human health studies have shown that in healthy adults, respiratory symptoms of bloom exposure disappear rapidly after removal from aerosol exposure, while in people with asthma and other respiratory issues, symptoms can persist for extended periods (Milian et al., 2007). Fleming et al. (2011) also point out how improvements in brevetoxin detection methodology have led to the detection of measurable brevetoxin loads within live fish, leading to potential "brevetoxin fish poisoning" (not just shellfish poisoning) with consumption of live fish. The potential risk of brevetoxin fish poisoning is further supported by increases in hospital admissions related to gastrointestinal issues during blooms (Kirkpatrick et al., 2010).

The majority of research on the environmental impacts of $K$. brevis blooms has focused upon acute organismal impacts. Brevetoxins are potent neurotoxic ichthyotoxins and both live cells and dissolved brevetoxins in seawater can be absorbed across fish gills (Landsberg, 2002; Naar et al., 2007), resulting in loss of muscle coordination, paralysis and eventually death via respiratory failure (Landsberg, 2002). Blooms frequently result in extensive fish kills as well as seabird and marine mammal mortalities (see reviews in Landsberg, 2002; Landsberg et al., 2009). Dead fish accumulate on beaches, and besides being an unsightly deterrent to beach dependent tourism industries, may also serve as a vector of brevetoxin to sea and shorebirds (Van Deventer et al., 2012). These kills can lead to local declines in fish stock (Landsberg et al., 2009) or in some cases impact multiyear classes of especially sensitive fish (DiLeone and Ainsworth, 2019), impacting longer term community structure and diversity (Gannon et al., 2009; DiLeone and Ainsworth, 2019). Because of these large, frequent fish kills associated with blooms, it was assumed that brevetoxins could not accumulate in fish at sublethal levels, or be transferred through food webs to different trophic levels. However, Flewelling et al. (2005) reported elevated brevetoxin levels in the tissue of live fish collected from the wild as well as in whole fish contained in the stomachs of dolphins (Tursiops truncatus) killed in a marine mammal mass mortality in the Florida Panhandle in 2004. Additionally, Naar et al. (2007) demonstrated that brevetoxins can accumulate in both omnivorous and planktivorous fish by dietary transfer in both the laboratory and in the natural environment and persist for up to a year after the bloom (Naar et al., 2007).

Karenia brevis blooms can also result in sea turtle and marine mammal moralities, including dolphins and manatees (Flewelling et al., 2005). In the 2002 bloom associated manatee mortality event, Flewelling et al. (2005), Fire et al. (2007, 2015) demonstrated that fish and seagrass served as the vector of brevetoxin to higher trophic levels after they accumulated high concentrations of brevetoxins during blooms. Sea turtles are also negatively impacted by $K$. brevis blooms with unusually high strandings reported for both east and west Florida coasts during blooms (Foley et al., 2019), especially from 2003 to 2006 (Capper et al., 2013; Fauquier et al., 2013). Sublethal impacts of on turtles have also been noted (Walsh et al., 2019), suggesting that sublethal brevetoxin impacts on these species may be pervasive during blooms and requires further study.

Karenia brevis blooms can also have secondary effects related to bloom associated hypoxia or anoxia (Smith, 1975, 1979; Hu et al., 2006). Large anoxic events were associated with a bloom in the early 1970's (Smith, 1975, 1979) as well as the severe 2005 bloom off central west Florida (Landsberg et al., 2009; Dupont et al., 2010). The 2005 event comprised more than 2,000 sq. miles in an area offshore of central west Florida and likely resulted from $K$. brevis cells trapped in bottom waters by a warm, stratified water column which over time (with bacterial decomposition of dead biota) resulted in a large area of bottom anoxia (Landsberg et al., 2009). The anoxia was only relieved when the water column was almost instantaneously mixed by the passage of Hurricane Katrina 200 miles to the west (Weisberg et al., 2009).

\section{Pyrodinium bahamense}

The thecate dinoflagellate Pyrodinium bahamense is the HAB species responsible for the most HAB related paralytic shellfish poisoning (PSP) fatalities annually (Usup et al., 2012) since it first bloomed in Papua New Guinea in 1972 (Maclean, 1977). This species is generally considered a monospecies, currently with two accepted varieties, $P$. bahamense var. compressum, which is restricted to the Pacific Ocean, and P. bahamense var. bahamense, which occurs in the Atlantic Ocean and Caribbean Sea (Steidinger et al., 1980; Badylak et al., 2004) although there remains some taxonomic debate as to the validity of these two varieties (Balech, 1985; Matsuoka et al., 1989; Morquecho, 2008). Currently the two varieties are only reported to co-occur in the Arabian Sea (Glibert et al., 2002) and the Pacific coast of Mexico (Garate-Lizarraga and Gonzalez-Armas, 2011). Besides the taxonomic differences between the two varieties, Steidinger et al. (1980) also proposed that only the Pacific variety was toxic, while the Atlantic variety was not. In 2002, however, Landsberg et al. (2006) demonstrated that P. bahamense var. bahamense 
can produce paralytic shellfish toxins (PST) including saxitoxin (STX), decarbamoyl STX and $M$-sulfocarbamoyl toxins, in clonal cultures and in natural bloom samples from the Indian River Lagoon (IRL). Since 2002, frequent commercial shellfish bed closures have occurred in the IRL and more recently in Tampa Bay and Charlotte Harbor on Florida's west coast which also experience $P$. bahamense var. bahamense blooms (Phlips et al., 2006; Lopez et al., 2015, 2019).

Pyrodinium bahamense has a typical dinoflagellate life cycle, which includes a heterothallic sexual life cycle that results in an easily recognizable, large, round, spiny resting cyst (Usup et al., 2012). In the paleontological classification system the cyst of P. bahamense is referred to as Polysphaeridium zoharyi (Bujak et al., 1980). Cysts of P. bahamense exhibit a broader geographic distribution than the reported distribution of vegetative cells (Usup et al., 2012). Usup et al. (2012) further suggested that this widespread cyst distribution may underlie the expansion of $P$. bahamense var. compressum in the Pacific Ocean since the early 1980's (Maclean, 1989), likely in response to environmental changes rather than new introductions.

Badylak and Phlips (2004) and Phlips et al. (2004, 2006, 2011, 2015) have examined the bloom dynamics of $P$. bahamense var. bahamense in the IRL as part of a monitoring program. This species did not occur below $20^{\circ} \mathrm{C}$ (Phlips et al., 2006, 2011) and had a euryhaline salinity tolerance (10-45) (Phlips et al., 2006). P. bahamense var. bahamense is found year round in Florida Bay at low concentrations (Phlips et al., 2006), but higher biomass blooms exhibit a seasonality in more northern areas such as Tampa Bay and the IRL, appearing after temperatures exceed $20^{\circ} \mathrm{C}$ (Phlips et al., 2006). Blooms generally coincide with wet periods with heavy rainfall (Phlips et al., 2006) and Phlips et al. (2020) report a relationship between the peak biomass of $P$. bahamense var. bahamense blooms and high rainfall El Niño periods. Although this relationship with rainfall suggests that nutrient enrichment may be important in supporting these blooms, little is known about the nutrient requirements of $P$. bahamense var. bahamense. This species grows better in culture medium enriched in natural organic acids such as humic acids and soil extract supplements (McLaughlin and Zahl, 1961; Usup, 1996; Landsberg et al., 2006) and selenium (Usup, 1996; Landsberg et al., 2006). Usup et al. (2012) observed that $P$. bahamense is often found in areas adjacent to mangrove forests, which are a rich source of dissolved organic matter in Florida coastal waters (Jaffé et al., 2004).

A second route of potential human saxitoxin exposure (saxitoxin puffer fish poisoning, SPFP, Table 1) was described by Landsberg et al. (2006). From 2002 through 2004, 28 cases were reported from Florida, New Jersey, New York, and Virginia in which people became sick consuming pufferfish which originated in the Indian River Lagoon. Analysis of fish remains revealed saxitoxin in fish tissue (Quilliam et al., 2002) and P. bahamense was putatively identified as the toxin source (Landsberg et al., 2006). Monitoring of pufferfish in the IRL for saxitoxin (Abbott et al., 2009) recorded highest levels of saxitoxin in Southern and Bandtail puffer fish skin and elevated concentrations in the gut, gonads and liver. In July 2004, the Florida Fish and Wildlife Conservation Commission issued a permanent prohibition on take of puffer fish in waters of Volusia, Brevard, Indian River, St. Lucie, and Martin Counties.

\section{Ciguatera Dinoflagellates}

Ciguatera fish poisoning (CFP) is a common human illness syndrome resulting from the consumption of large carnivorous marine finfish that have been contaminated with ciguatoxins (CTXs) originating from two benthic dinoflagellate genera, Gambierdiscus and Fukuyoa (Friedman et al., 2008). While Dawson et al. (1955) were the first to suggest that reef fish become toxic by feeding on poisonous algae, Yasumoto et al. (1977) first identified the dinoflagellate involved as Gambierdiscus based on type species of Gambierdiscus toxicus R. Adachi \& Y Fukuyo described from the Gambier Islands in French Polynesia (Adachi and Fukuyo, 1979). Recently, several globularly shaped Gambierdiscus species have been reclassified into a new genus, Fukuyoa, based on their phylogenetic and morphological divergence (Holmes, 1998; Litaker et al., 2009; Gómez et al., 2015). Other genera have also been shown to be capable of producing less toxic ciguatera-like toxins, including Prorocentrum, Amphidinium, Ostreopsis, and Coolia (Nakajima et al., 1981; Tindall et al., 1984; Tindall et al., 1990; Babinchak et al., 1986). Representatives of all these genera have been reported from Florida coastal waters, especially in warmer south Florida waters in Florida Bay and Florida Keys (Table 2).

Ciguatoxins are lipid-soluble polyether compounds with skeletal structures comprised of 13-14 transfused ether rings (Parsons et al., 2012) which act on sodium ion channels causing cell membrane excitability and instability. More than 29 precursor ciguatoxins have been identified from G. toxicus cells and herbivorous and carnivorous fish from the Pacific Ocean Lehane and Lewis (2000) and a lesser amount, 12 congeners, identified from Caribbean and Atlantic Ocean fish (Dickey and Plakas, 2010). Significant variations in toxin production occur between G. toxicus clones (Dickey and Plakas, 2010).

Commonly associated with reef environments, these dinoflagellate genera are epiphytic, living associated with sand, coral and macroalgal substrates. Ciguatoxins are accumulated by herbivorous reef fish while grazing and these fat soluble toxins are subsequently biomagnified through trophic levels to large predatory fish. High concentrations of ciguatoxins in these fish are undetectable by appearance, taste or smell and are not destroyed by cooking or freezing. More than 400 species of fish are reported to be associated with ciguatera poisoning (Ahmed, 1991; Chateau-Degat et al., 2007; Azziz-Baumgartner et al., 2012; Soliño and Costa, 2020), but the majority of these species probably serve as vectors to higher trophic levels. The vast majority of outbreaks globally directly involve large carnivorous fish such as snappers, groupers, wrasses, and barracudas (Chinain et al., 2020a). In Florida, de Sylva (1994) reported that barracuda comprised 35 of 73 cases of CFS in Florida from 1954 to 1992, followed to a lesser extent by hogfish, groupers and jacks while Radke et al. (2015) report that barracuda and grouper were the most common fish involved in reported CSP cases, 18 and $31 \%$ of confirmed ciguatera outbreaks, respectively, between 2001 and 2011 . 
TABLE 2 | Ciguatera associated dinoflagellate species reported from Florida waters.

\begin{tabular}{|c|c|c|}
\hline Species & Collection area & References \\
\hline Gambierdiscus sp. & Florida Bay & Parsons et al., 2012 \\
\hline Gambierdiscus toxicus Adachi \& Fukuyo & Florida Keys & $\begin{array}{l}\text { Taylor, 1979; Bergmann and Alam, 1981; Besada and Loeblich, } \\
\text { 1982; de Sylva, 1982; Babinchak et al., 1986; Indelicato and } \\
\text { Watson, 1986; Bomber, 1987; Bomber et al., 1988a,b; Morton } \\
\text { et al., } 1992\end{array}$ \\
\hline G. caribaeus Vandersea, Litaker, Faust, Kibler, Holland \& Tester & & Litaker et al., 2010; Accoroni et al., 2020 \\
\hline G. carolinianus Vandersea, Litaker, Faust, Kibler, Holland \& Tester & & Litaker et al., 2010; Rains, 2015 \\
\hline G. carpenteri Kibler, Litaker, Faust, Holland, Vandersea \& Tester & & Litaker et al., 2010; Rains, 2015 \\
\hline G. yasumotoi Holmes & & Rains, 2015 \\
\hline G. belizeanus Faust & Florida Keys & Litaker et al., 2017 \\
\hline Fukuyoa sp. & Florida Keys & Accoroni et al., 2020 \\
\hline Coolia sp. & Florida Keys & Besada and Loeblich, 1982; Accoroni et al., 2020 \\
\hline Coolia monotis Meunier & Florida Keys & Morton et al., 1992 \\
\hline Coolia santacroce Karafas, Tomas \& York & Florida Keys & Accoroni et al., 2020 \\
\hline Ostreopsis sp. & Florida Keys & $\begin{array}{l}\text { Besada and Loeblich, 1982; Babinchak et al., 1986; Bomber } \\
\text { et al., 1988a; Accoroni et al., } 2020\end{array}$ \\
\hline Ostreopsis heptagona Schmidt Norris, Bomber \& Balech & Florida Keys & Bomber, 1987; Bomber et al., 1988a; Morton et al., 1992 \\
\hline Ostreopsis siamensis & Florida Keys & Morton et al., 1992 \\
\hline Prorocentrum spp. & Florida Keys & de Sylva, 1982; Accoroni et al., 2020 \\
\hline Prorocentrum lima (Ehrenberg) Stein & Florida Keys & $\begin{array}{l}\text { Bomber et al., 1985, 1988a; Morton et al., 1992; Accoroni } \\
\text { et al., } 2020\end{array}$ \\
\hline Prorocentrum hoffmanianum Faust & Florida Keys & Accoroni et al., 2020 \\
\hline P. concavum Fukuyo & Florida Keys & Bomber et al., 1988a; Morton et al., 1992 \\
\hline P. emarginatum Fukuyo & Florida Keys & Bomber et al., 1988a; Accoroni et al., 2020 \\
\hline Prorocentrum rhathymum Loeblich III, Sherley \& Schmidt & Florida Bay & Accoroni et al., 2020 \\
\hline Sinophysis sp. & Florida Bay & Accoroni et al., 2020 \\
\hline Amphidinium sp. & Florida Bay & Accoroni et al., 2020 \\
\hline
\end{tabular}

Ciguatera fish poisoning (CFP) is most common in tropical and subtropical environments $\left(35^{\circ} \mathrm{N}\right.$ to $35^{\circ} \mathrm{S}$, Quod and Turquet, 1996; Pottier et al., 2001). Although ciguatera originally occurred primarily in the tropic and subtropics, the expansion of global travel as well as the importation of fish from the tropics (Van Dolah, 2000; de Haro et al., 2003) has expanded its range, and now CFP is the most frequently reported seafood illness in the United States (Fleming et al., 1997; Lipp and Rose, 1997). Annual estimates of individuals affected by ciguatera shellfish poisoning globally range from approximately 10,000 (Bruslé, 1997) to 50,000 (Gervais and Maclean, 1985) to greater than 500,000 per year (Fleming et al., 1998). Within Florida, there is a long history of reports of toxic fish that implicate ciguatoxins. de Sylva (1994) cites a report by Gudger of incidences of toxic barracuda off Key West in 1918 (Gudger, 1918) and subsequent reports of toxic barracuda in the 1940's (Colby, 1943), 1950's (Phillips and Brady, 1953; de Sylva, 1956), 1960's (Baratta and Tanner, 1970) and 1970's (Barkin, 1974; Deichmann et al., 1977). While CSP is more common in Florida's southern counties (Radke et al., 2015), given the large geographical range of predatory fish involved, populations throughout the state that consume these fish are at risk of CSP.

Reviews of the clinical, epidemiological and public health management of CFP are provided by Friedman et al. (2008, 2017), Dickey and Plakas (2010), and Chinain et al. (2020a,b). Ciguatera fish poisoning is characterized by gastrointestinal, neurological, and rarely, cardiovascular effects. Symptoms typically develop within $72 \mathrm{~h}$ after fish consumption, often in less than $6 \mathrm{~h}$ (Ahmed, 1991). The complexities of the toxins result in up to 355 different symptoms reported in ciguatera victims (Sims, 1987). Although fatalities are relatively rare (0.1-12\%, Azziz-Baumgartner et al., 2012), neurological symptoms may persist and develop into a debilitating chronic condition (Mines et al., 1997; Palafox and Buenconsejo-Lum, 2001; Friedman et al., 2008) or may be reinitiated by further consumption of ciguateric fish (Poli, 1982).

The epidemiology of CFP is complex (Friedman et al., 2017; Chinain et al., 2020a,b), which has contributed to difficulties in reporting and management of risk for CFP both globally and locally in Florida. Cases are difficult to diagnose and often only a small percentage of cases are reported (Tester et al., 2010). Radke et al. (2015) examined the epidemiology of ciguatera poisoning in Florida between 2001 and 2011 and reported an incidence of 5.6 per 100,000 individuals, with Hispanic populations, primarily in southern Florida Monroe and Dade counties, having the highest incidence rate and risk. This is consistent with Lawrence et al. (1980)'s estimate of 5-500 cases per 100,000 individuals for 19741976 in Florida if the entire state population is considered. These annual caseloads are low compared with regions in the south Pacific Ocean such as French Polynesia, where CFP is highly endemic with 140 cases per 10,000 individuals (Chinain et al., 2010). However, both studies as well as Begier et al. (2006) suggest that these Florida incidence rates are underestimates of 
the true number of CFP cases in Florida due to underreporting, especially underreporting of non-outbreak associated ciguatera cases (Begier et al., 2006). Indeed, Poli (1982) estimated the annual total case load for combined Dade, Broward, Monroe, and Palm Beach counties at 1,300 cases annually.

There is some evidence that ciguatera is expanding into the northern GoM and north along the United States Atlantic seaboard (Villareal et al., 2007; Gingold et al., 2014). Rongo and van Woesik (2011) present two competing hypotheses to account for CFP outbreaks, the new surface hypothesis and the climate oscillation hypothesis, both of which could apply to Florida and are not mutually exclusive. CFP events are often associated with disturbances to coral reefs, including hurricanes, bleaching, blasting and eutrophication (see lists in Bruslé, 1997; Lehane and Lewis, 2000), which theoretically result in additional substrate availability for macroalgal colonization and hence ciguatera dinoflagellate substrate. The spread of ciguatera north in the GoM via the spread of oil platforms which serve as artificial reef and fisheries enhancement structures (Villareal et al., 2007) supports the former hypothesis. Gingold et al. (2014) examined reports to the United States Poison Control Center for CFP from 2001 to 2011 and found an association between monthly CFP calls and both warmer sea surface temperatures and increased tropical storm frequency. This supports the findings of Tester et al. (2010) who reported the optimal temperature for growth for 5 of 6 G. toxicus strains was $>29^{\circ} \mathrm{C}$, and that the number of days with temperatures $>29^{\circ} \mathrm{C}$ in the Caribbean has more than doubled in the last 3 decades. Regional projections based on a model output (Kibler et al., 2017) indicated the highest G. toxicus growth potential was in the Caribbean Sea shelf waters, with moderate growth in southern Florida and the GoM; the lowest growth potential was in the northern GoM and along the United States south Atlantic coast. If climate change increases $2.5-3.5^{\circ} \mathrm{C}$ in the Caribbean as projected over the next 100 years, the Gingold et al. (2014) model suggests that the United States will see a 200-400\% increase in CFP incidence. This agrees with patterns evident in the Pacific Ocean, where Hales et al. (1999) report strong positive correlations between CFP and sea surface temperatures in warming areas. Other variables that could underlie increases in CFP include south Florida's high immigration rates, changes in fisheries which decrease the relative abundances of larger ciguateric fish, consumer awareness and avoidance of known ciguateric fish species and laws prohibiting or restricting sale of these fish (de Sylva, 1994).

\section{Diatom HAB Species \\ Pseudo-nitzschia Species}

Diatoms can be harmful either directly, through toxicity, or indirectly through the secondary effects. This includes high biomass resulting in water column anoxia or hypoxia, mucilage production clogging gills, frustule spines irritating gills (Fryxell and Villac, 1999; Fryxell and Hasle, 2003; Sunesen et al., 2009) or a negative influence on aquaculture product taste (Sunesen et al., 2009). Toxicity is not a common feature of diatoms, only three genera, Pseudo-nitzschia, Nitzschia, and Halamphora, are known to be toxic (Sunesen et al., 2009). The first human poisoning directly linked to a toxic diatom occurred in November of 1987, when a group of people consumed mussels harvested from Prince Edward Island, Canada (Subba Rao et al., 1988; Bates et al., 1989) and became ill with gastrointestinal distress, confusion, disorientation, memory loss, and coma. Three individuals died. The causative toxin and responsible diatom was later identified as domoic acid (DA) from the species Pseudo-nitzschia multiseries (Kotaki et al., 2000; Lundholm and Moestrup, 2000) and its related human syndrome was called Amnesic Shellfish Poisoning (ASP).

Lefebvre and Robertson (2010) have suggested that DA containing diatom blooms are increasing globally. Of the three known toxic diatom genera, only one, Pseudo-nitzschia, a chain-forming, pelagic, cosmopolitan pennate diatom, has been associated with toxins in the GoM. Parsons and Dortch (2002) examined Pseudo-nitzschia in Louisiana waters and reported that Pseudo-nitzschia abundance has increased in the GoM since the 1950's, with sedimentary records suggesting that this increase may be related to increases in Mississippi River nutrient inputs. High Pseudo-nitzschia cell concentrations have also been reported in Alabama coastal waters linked to groundwater nutrient discharge (Liefer et al., 2009; MacIntyre et al., 2011). Pseudo-nitzschia species are a common component of marine phytoplankton communities in Florida's estuaries and coastal waters where blooms are common, especially in the spring and fall (Bates et al., 2018). Steidinger et al. (2018) reports that of the 20 known toxic Pseudo-nitzschia species identified from the GoM, 11 have been reported from Florida waters (Table 3).

Pseudo-nitzschia species potentially produce domoic acid (DA), a low molecular weight ( $\sim 311 \mathrm{Da})$, water soluble (Falk et al., 1991) amino acid that is toxic to birds and mammals, including humans (see Todd, 1993; Bejarano et al., 2008; Lelong et al., 2012 for reviews). DA binds to glutamate receptors in the central nervous system, exciting neurons and causing $\mathrm{Ca}^{+}$ input leading to neural death (Chand, 2009). While the impacts of acute exposure to DA in humans is established (Todd, 1993; Pulido, 2008; Lefebvre and Robertson, 2010; Saeed et al., 2017), the potential impacts of long-term low-level chronic exposure in "at risk" human populations are currently unknown (Lefebvre and Robertson, 2010). Biovalves filter Pseudo-nitzschia cells and concentrate DA with little impact on themselves but can serve as a vector to marine mammals and humans who consume the shellfish. Seabirds can also accumulate DA and be adversely impacted, likely through consumption of planktivorous fish such as mackerel (Sierra Beltrán et al., 1997). The first significant impacts of DA on wildlife occurred in Monterey Bay in 1991 (Work et al., 1993a,b) and mortality events involving DA and seabirds and marine mammals as well as toxic shellfish have become common on the west coast since 1991 (Scholin et al., 2000; see Trainer et al., 2012 for review), and more recently in the Gulf of Maine and adjacent waters (Hubbard et al., 2015; Bates et al., 2018). In Florida, filter-feeding mollusks such as mussels, cockles, oysters, hard and razor clams, scallops, squids and crustaceans have all been shown to accumulate DA (O'Dea, 2012). DA has also been shown to absorb to sediments (Burns and Ferry, 2007) suggesting that it may be present in benthic food chains. The detection of low levels of DA in dolphins (T. truncatus) 
TABLE 3 | Toxic Pseudo-nitzschia species reported from Florida estuarine, coastal and marine waters.

\begin{tabular}{ll}
\hline Species & References \\
\hline $\begin{array}{l}\text { Pseudo-nitzschia brasiliana } \\
\text { Lundholm, Hasle \& Fryxell }\end{array}$ & Parsons et al., 2012 \\
Pseudo-nitzschia calliantha & Phlips et al., 2011; O'Dea, 2012; \\
Lundholm, Moestrup \& Hasle & Parsons et al., 2012 \\
Pseudo-nitzschia cuspidata (Hasle) & O'Dea, 2012; Parsons et al., 2012; \\
Hasle & Hubbard et al., 2014, 2015 \\
Pseudo-nitzschia delicatissima & Lehman and Wood, 1996; Moreno \\
(Cleve) Heiden & et al., 1996; Hernández-Becerril, 1998; \\
& Moreno-Gutiérrez, 2008; \\
& Gallegos-Martínez et al., 2009; \\
& Krayesky et al., 2009; \\
& Quijano-Scheggia et al., 2011; O’Dea, \\
& 2012; Parsons et al., 2012 \\
Pseudo-nitzschia granii (Hasle) & O'Dea, 2012
\end{tabular}

\section{Hasle}

Pseudo-nitzschia linea Lundholm, Hasle and G.A.Fryxell

Pseudo-nitzschia micropore

Priisholm, Moestrup \& Lundholm

Pseudo-nitzschia multiseries

(Hasle) Hasle

Pseudo-nitzschia obtusa (Hasle)

Hasle \& Lundholm

Pseudo-nitzschia pungens

(Grunow ex Cleve) Hasle

Pseudo-nitzschia

pseudodelicatissima complex

(Hasle) Hasle
Lundholm et al., 2002

O'Dea, 2012

O'Dea, 2012

Sullivan, 1978; Krayesky et al., 2009

Saunders and Glenn, 1969; Lehman and Wood, 1996; Hernández-Becerril, 1998; Moreno-Gutiérrez, 2008;

Krayesky et al., 2009;

Gallegos-Martínez et al., 2009; Licea

et al., 2011; O'Dea, 2012; Parsons

et al., 2012; Hubbard et al., 2014

Conger et al., 1972;

Hernández-Becerril, 1998;

Moreno-Gutiérrez, 2008;

Gallegos-Martínez et al., 2009;

Krayesky et al., 2009; Licea et al.,

2011; O'Dea, 2012; Parsons et al.,

2012; Bargu et al., 2016

O'Dea, 2012

Pseudo-nitzschia turgidula

(Hustedt) Hasle

sampled live during health related surveys in Sarasota Bay (Twiner et al., 2011) and Florida's Panhandle region (Schwacke et al., 2010) and in menhaden and seawater off Louisiana (Del Rio et al., 2010) also supports its presence in pelagic food chains in the eastern GoM. Plasma and intestinal samples from a juvenile green sea turtle (Chelonia mydas) stranding event in southwest Florida coastal waters in 2014-2015 also found DA above regulatory limits (Flewelling et al., 2015).

Only three closures of commercial shellfish beds in Florida have resulted from the detection of DA above regulatory limits (20 $\mathrm{g} \mathrm{g} \mathrm{gm}^{-1}$ tissue), all within St. Joseph Bay, a small enclosed embayment in the central panhandle (O'Dea et al., 2013; Hubbard et al., 2015, 2017). In May of 2013, a 2-month closure was enacted when DA was detected in eastern oysters (Crassostrea virginica) at concentrations of $76 \mu \mathrm{g} \mathrm{g}^{-1}$ tissue (O'Dea et al., 2013). Other seafood, bay scallops (Argopecten irradians) and pen shells (Atrina rigida), also tested above regulatory limits over

the course of the closure coincident with a bloom of Pseudonitzschia cuspidata (Hasle) Hasle. In October of 2014, DA was again detected in oysters in St. Joseph Bay, coincident with a mixed phytoplankton assemblage that included $P$. cuspidata (Hubbard et al., 2015) resulting in a 3 month closure. From July to September of 2017, a third closure was resulted from detection of DA in whole scallops and pen snails above regulatory limits (Bates et al., 2018). The coincident phytoplankton assemblage during the early stages of closure included Pseudo-nitzschia pseudodelicatissima (Hasle) Hasle (Hubbard et al., 2015).

Monitoring for toxic Pseudo-nitzschia species and the potential risks associated with DA is difficult for a variety of reasons. Pseudo-nitzschia is a ubiquitous member of coastal phytoplankton communities in Florida, but difficult to taxonomically identify to the species level without use of electron microscopy to define frustule morphology. Toxicity is highly variable between species, or even different strains of a Pseudonitzschia species (Thessen et al., 2009; Bates et al., 2018) and varies with environmental (e.g., upwelling and river runoff) and physiological [e.g., growth rate (Bates et al., 1998; Bates and Trainer, 2006; Howard et al., 2007)] conditions (see Trainer et al., 2012; Bates et al., 2018). Current reservoirs of DA in the environment are unknown but are likely as Bellinger and Hagerthey (2010) reported DA from periphyton in Everglades. While areas with an established history of DA regulatory closures are more routinely monitored (e.g., St. Joseph Bay), the increasing incidences of Pseudo-nitzschia spp. blooms globally and in the GoM, as well as links between blooms and river nutrient inputs (Parsons and Dortch, 2002) in the GoM, suggest that the frequency of Pseudo-nitzschia blooms and potentially DA occurrences will increase in the GoM and Florida.

\section{Cyanobacterial HAB Species}

Cyanobacteria (also known as blue-green algae) are an evolutionarily old (Hoffman, 1999), diverse group of photosynthetic bacteria that have adapted to a wide variety of habitats, including soils and fresh, estuarine and marine waters (Chorus and Welker, 2021). They are biogeochemically important in marine waters as they contribute significantly to the global carbon and nitrogen $(\mathrm{N})$ cycles via $\mathrm{N}_{2}$ fixation (Graham and Wilcox, 2000; Castenholz et al., 2001) and they often dominate plankton assemblages in freshwater systems. They are of importance to human and environmental health because of the $\sim 2,000$ to 8,000 species identified worldwide (Nabout et al., 2013), and many are able to form extensive blooms and can contain bioactive compounds (Dow and Swoboda, 2000), including a large array of potent toxic and bioactive compounds (Dow and Swoboda, 2000; Shimizu, 2003).

Cyanobacteria are responsible for the majority of freshwater HABs (cyanoHABs) globally (Lopez et al., 2008) and can contain a variety of hepatotoxins [e.g., microcystins (MC) and nodularins], cytotoxins (e.g., cylindrospermopsins), and neurotoxins [e.g., guanitoxin (formerly anatoxin-a(S), Fiore et al., 2020)] which can impact human health and have embryo-lethal, teratogenic, gonadotoxic, mutagenic, and tumor promoting impacts (Kirpenko et al., 1981; Carmichael, 2001; Zanchett and Oliveira-Filho, 2013). Recently, the isolation and identification 
of a non-proteinaceous amino acid with neurotoxic properties, $\beta$ - $N$-methylamino-L-alanine (BMAA) (Cox et al., 2003; Metcalf and Codd, 2012), from cyanobacteria and microalgae in both freshwater and marine environments (e.g., Cox et al., 2005; Jiang and Ilag, 2014; Jiang et al., 2014; Lage et al., 2014; Violi et al., 2019) has been a cause for concern due to its identification as a risk factor for neurodegenerative diseases (Bradley and Mash, 2009; Chiu et al., 2011). Evidence supporting a potential link between BMAA exposure and clinical manifestations of Amyotrophic Lateral Sclerosis (ALS), Parkinsonism, and Alzheimer's disease (AD) globally have been variable due to inconsistencies in the analytical methodologies and poor reporting (see reviews by Faassen, 2014; Chernoff et al., 2017) as well as the potential impact of culture conditions and clone variability on alga and cyanobacterial BMAA production (Chernoff et al., 2017). For example, axenic cultures of the filamentous cyanobacteria Leptolyngbya PCC73110 exhibited high concentrations of BMAA, but similar measurements of field samples containing a consortia of cyanobacterial species registered two orders of magnitude lower (Spáèil et al., 2010). The detection of BMAA in some diatoms and dinoflagellates (Jiang et al., 2014; Lage et al., 2014) as well as freshwater and marine cyanobacteria (Metcalf et al., 2021) and biota (Brand et al., 2010) from Florida, including shark fin and shark fin supplements (Mondo et al., 2012, 2014) and stranded dolphins (Davis et al., 2019) suggests that the distribution and potential environmental and human health impacts of BMAA in Florida as well as its potential for biomagnification through aquatic food chains (Faassen, 2014) requires further study. Also unknown with regards to cyanobacterial related human health risks in Florida is the possible exposure to cyanotoxins resulting from irrigation of food crops with cyanobacteria-contaminated water (see references in Miller and Russell, 2017). Although many variables influence cyanotoxin accumulation (e.g., plant stage upon exposure, soil bacteria community, toxin concentration, irrigation volumes, and length of exposure), there is a growing body of evidence supporting the potential for cyanotoxin accumulation, especially microcystins, in food crops (Codd et al., 1999; McElhiney et al., 2001; Mohamed and Al Shehri, 2009; Hereman and Bittencourt-Oliveira, 2012; Liang and Wang, 2015; Cordeiro-Araújo et al., 2016; do Carmo Bittencourt-Oliveira et al., 2016; Machado et al., 2017).

Research on the human health impacts of cyanobacteria have largely focused on exposure to and effects of ingesting cyanotoxin contaminated drinking waters (Falconer, 1999; Fleming et al., 2002; Codd et al., 2005; Falconer and Humpage, 2005; Hoeger et al., 2005; Cheung et al., 2013; He et al., 2016; Chorus and Welker, 2021). The EPA established Health Risk Advisory (HRA) levels for the cyanotoxins, cylindrospermopsin and microcystin in drinking waters in 2015 (EPA-820R15101, June 2015, EPA820R15100, June 2015) and water quality and swimming advisories in 2019 (EPA 822-R-19-001, May 2019). In Florida, Fleming et al. (2002) did report an association between possible exposure to surface water containing cyanotoxins and risk of primary haptocellular carcinoma (HCC), which was not present with ground water or in the general population, suggesting the health effects of cyanobacterial exposure in Florida need further study. Metcalf et al. (2021) has reported both microcystins and BMAA from a variety of freshwater, estuarine and marine environments in south Florida. Little is known of the potential human health impacts of aerosolized cyanotoxins, including BMAA, or the controls on the toxin aerosolization process. Plaas and Paerl (2020), in a recent review of inhalation specific threats associated with cyanotoxins, suggest that aerosolized cyanotoxin production associated with freshwater cyanoHABs may be more widespread than currently known and report values ranging from $91 \mathrm{fg} \mathrm{m}^{3}$ to $50+20 \mathrm{ng} \mathrm{m}^{3}$. There are many anecdotal reports describing illnesses related to cyanobacterial exposure in freshwater (Stewart et al., 2006a,b). Backer et al. $(2008,2010)$ demonstrated that Microcystis can be transferred to human nasal cavities during recreational activities (e.g., swimming and boating) in Microcystis blooms. Schaefer et al. (2020) reported measurable microcystins in the nasal mucosa of 95\% of individuals in contact with Microcystis bloom waters in south Florida, with a statistically significant difference between individuals with direct bloom contact and those with no recent contact, and higher concentrations among occupationally exposed individuals. The environmental conditions and length of exposure that cyanotoxins are subjected to during aerosolization may also be important. Cheng et al. (2007) demonstrated that transfer of microcystins to air occurs via a bubble bursting process. Measurements of microcystin-LR aerosol degradation (Jang et al., 2020) have shown that it quickly decays from interactions with sunlight, hydroxyl radicals and ozone (54 min lifetime), although it can still be impactful. Additionally, Sutherland et al. (2021) has reported the aerosolization of anatoxin-a from cyanobacterial populations in a freshwater pond on Nantucket Island, Massachusetts (United States). Combined with reports of aerosolized nodularins (Wood and Dietrich, 2011; Gambaro et al., 2012) and BMAA (Banack et al., 2015), these reports suggest that aerosolization may be widespread among cyanotoxins and is of concern for human health, especially in light of a global increase in cyanoHABs in relation to climate change. The clinical impacts of this inhalation route of cyanotoxin exposures are unknown, as are the acute versus chronic exposure impacts and further study is warranted. Research on the identification and measurement of aerosolized cyanotoxins as well as their links with human health is in its infancy.

CyanoHABs with associated toxins have been reported from more than 50 countries and almost all states in the United States (Loftin et al., 2016). A diverse array of cyanobacterial species have been documented from many Florida waters, including freshwater springs, ponds and lakes, rivers, estuaries and marine environments. Increasingly, toxic cyanoHABs and/or their toxins are being documented in additional freshwater systems within the state, including the St John's River (Havens et al., 2019; Landsberg et al., 2020), Lake Okeechobee (Havens et al., 2003; Kramer et al., 2018), the St. Lucie River (Kramer et al., 2018) and the Caloosahatchee River (Metcalf et al., 2021) as well as some estuarine and marine environments within Florida (Paerl et al., 2008; Tiling and Proffitt, 2017; Lefler et al., 2021; Metcalf et al., 2021). These freshwater and marine cyanoHABs are not necessarily separate events. Some toxic freshwater cyanobacterial 
blooms, along with their toxins (e.g., toxic Microcystis blooms in Lake Okeechobee), are being transferred to estuarine and coastal waters (Oehrle et al., 2017; Metcalf et al., 2021; Tatters et al., 2021) through water management actions (Kramer et al., 2018), a trend for cyanoHABs that is occurring globally (Preece et al., 2017). Metcalf et al. (2021) reports that during analysis of a co-occurring 2018 bloom of Microcystis spp. in Lake Okeechobee and Karenia brevis in the Gulf of Mexico, brevetoxin was detected at low salinities $\left(0.4 \mathrm{mS} \mathrm{cm}^{-1}\right)$ and microcystin-LR at higher salinities (41 $\mathrm{mS} \mathrm{cm}^{-1}$ ), indicating that there may be synergistic effects of co-occurring toxins at the freshwater-marine interface.

The first report of toxic cyanobacterial impacts in Florida is relatively recent. Carmichael (1992) reported the first incidence of cyanobacterial toxins associated with a cattle mortality near Lake Okeechobee, however Burns (2008) speculated that cyanoHABs have probably always been present in Florida freshwaters given the prevalence of underlying phosphatic deposits in the state. Shannon and Brezonik (1972) noted the widespread presence of Microcystis, Dolichospermum, and Microseira in 13 lakes in north central Florida and Nordlie (1976) noted Anabaena and Aphanizomenon in 3 eutrophied Florida lakes. Analysis of sediment cores from freshwater lakes within the state confirm the historical presence of cyanobacteria through pigment records (Whitmore et al., 2020), although the authors suggest cyanobacterial proliferation in recent decades has occurred in response to eutrophication (Riedinger-Whitmore et al., 2005). Many of Florida's freshwaters are increasingly being subjected to eutrophication (Riedinger-Whitmore et al., 2005; Havens et al., 2019), including Lake Okeechobee (Havens et al., $1996,2001)$ and cyanoHABs have become more frequent in the state (Paerl and Huisman, 2008; Havens and Steinman, 2015; Urquhart et al., 2017; Havens et al., 2019).

\section{Microcystis Species}

Microcystis is one of the most common bloom forming freshwater cyanobacterial genera globally (Fristachi and Sinclair, 2008) and in Florida (Burns, 2008). A coccoid, colonial genus, Microcystis cells do not form sheaths, but exist as either single cells, or more often in colonial form aggregated in large (up to $1 \mathrm{~cm}$ ) colonies within a mucilage comprised of polysaccharide compounds (Xu et al., 2014). Often these surface populations are evident as a thick layer of bright green 'slime' on the surface of freshwater ponds and lakes. Cells contain gas vacuoles which allow them to regulate buoyancy and maintain populations in surface waters under optimal light conditions yet still access nutrients at depth (Walsby et al., 1997). They are also resistant to predation (Michalak et al., 2013; Harke et al., 2016), which can contribute to the dominance and persistence of these blooms.

Microcystis has been shown to produce over 100 microcystin (MC) isomers (Díez-Quijada et al., 2019), guanitoxin (Fiore et al., 2020), and BMAA (Fristachi and Sinclair, 2008). Toxin production in Microcystis is strain specific, and blooms have been reported to contain both toxic and non-toxic strains (Davis et al., 2009; Wood et al., 2011). Microcystin-LR is the most common microcystin variant and has been classified as possibly carcinogenic to humans (International Agency for Research on Cancer Working Group on the Evaluation of the Carcinogenic Risks to Humans, 2010). Microcystins are monocyclic heptapeptides composed of $5 \mathrm{D}$-amino acids and 2 variable L-amino acids, which bind with protein phosphatase enzymes, causing cell damage. The major exposure route for humans is through the consumption of contaminated waters (World Health Organization, 1993), although dermal transfer, primarily during recreational exposure, exposure during kidney dialysis (Azevedo et al., 2002), consumption of contaminated food and inhalation are also potential routes (Codd et al., 1997). Given their chemical stability, high water solubility and environmental persistence in Florida freshwaters (Burns, 2008), cyanotoxin exposure is a major public health threat in Florida.

Microcystis is prevalent in Florida freshwaters (Williams et al., 2007; Burns, 2008) although toxicity levels are highly variable (Lefler et al., 2020). It forms extensive, reoccurring blooms in the diverse freshwater environments throughout the state, including the St. Johns River (Williams et al., 2007) and Lake Okeechobee (Ramani et al., 2012; Kramer et al., 2018) where blooms are released through water management practices into its tributaries, the St. Lucie (Oehrle et al., 2017; Kramer et al., 2018) and Caloosahatchee (Urakawa et al., 2020; Metcalf et al., 2021) Rivers. Microcystins are found year-round in these systems (Williams et al., 2007). Microcystis is not capable of atmospheric $\mathrm{N}_{2}$ fixation and relies upon the uptake of inorganic and organic $\mathrm{N}$ forms (Chen et al., 2019), including urea (Wu et al., 2015) and some amino acids (Dai et al., 2009). Increasing $\mathrm{N}$ concentrations generally increase the toxicity of both Microcystis cultures and blooms (see O'Neil et al., 2012 and references within). Kramer et al. (2018) found significant correlations between MC and total $\mathrm{N}$ in a bloom in Lake Okeechobee and suggested that high levels of $\mathrm{N}$ inputs favor Microcystis blooms. Increasing freshwater $\mathrm{N}$ inputs may thus favor the continued dominance of Microcystis blooms in Florida's freshwater systems.

\section{Picocyanobacterial HAB Species}

Several cyanobacterial species have formed extensive blooms with associated environmental harm in various lagoonal estuaries in Florida, including both Florida Bay, a shallow (average depth $\sim 1.5 \mathrm{~m}), 2,200 \mathrm{~km}^{2}$ bay bordered by the Everglades to the north and the Florida Keys to the east, and the Indian River Lagoon, a shallow coastal lagoon on Florida's east coast. Blooms of Synechococcus sp., a small ( $\sim 2 \mu \mathrm{m}$ diameter) picocyanobacterial genus, was first noted in 1987 in Florida Bay when a bloom resulted in the destruction of 4,000 ha of Thalassia spp. (Robblee et al., 1991). These blooms ultimately resulted in a loss of $30 \%$ of Florida Bay's seagrass (Hall et al., 1999; Durako et al., 2002) when an extended bloom resulted in extensive seagrass die-offs and associated mortalities (Glibert et al., 2009b,c). These blooms have become a reoccurring feature of Florida Bay, taking place in 1991 and frequently thereafter (Boyer et al., 1999; Phlips et al., 1999; Stumpf et al., 1999; Richardson and Zimba, 2002; Glibert et al., 2004, 2009b,c, 2010) through 2018 (Glibert et al., 2021). Although not directly toxic per se, these blooms reach such dense concentrations that light attenuation is diminished, affecting other primary producers such as seagrass. These blooms can be directly harmful to sponges through impacts on filter feeding (Lynch and Phlips, 2000; Peterson et al., 2006; Stevely et al., 2010). 


\section{Benthic and Epiphytic Cyanobacterial Proliferations}

Lyngbya and Microseira (formerly Lyngbya) are epiphytic bloom forming cyanobacteria genera that have been characterized as cyanoHABs in Florida. These species exhibit long branching filaments enclosed in mucilaginous sheaths that can form large, smothering, mats in both freshwater (Cowell and Botts, 1994; Stevenson et al., 2007) and marine (Paul et al., 2005; Paerl et al., 2008) environments, including Florida. Microseira wollei (Farlow ex Gomont) G.B. McGregor \& Sendall ex Kenins (formerly Lyngbya wollei) has an increasingly widespread distribution in Florida's freshwater springs and spring fed rivers, including the Silver Glen Springs and Blue Hole Springs (Foss et al., 2012) and Crystal (Cowell and Botts, 1994), and Homosassa (Harr et al., 2008) Rivers. Lyngbya majuscula has been reported extensive from estuarine and coastal environments in south Florida (Capper and Paul, 2008; Paerl et al., 2008; Sharp et al., 2009; Tiling and Proffitt, 2017). In addition to being aesthetically displeasing, these genera can contain an array of potential toxins and bioactive compounds (Carmichael et al., 1997; Singh et al., 1999; Milligan et al., 2000; Osborne et al., 2001; Berry et al., 2004; Foss et al., 2012) and their mats can be directly harmful to biota through their smothering impacts (Brinkhuis et al., 2008; Tiling and Proffitt, 2017) or indirectly by displacing more desirable biota within the system. They are also more resistant to chemical controls (Phlips et al., 1992; Dubose et al., 1997; see review by Wood et al., 2020). Their taxonomy is currently under extensive revision (Berthold et al., 2020; Lefler et al., 2021) with multiple new genera descriptions (e.g., Affixifilum, Neolyngbya, Leptochromothrix, Vermifilum, and Ophiophycus). Recent genetic analysis has also split the genus Lyngbya into new genera [e.g., Moorena (Engene et al., 2012), Limnoraphis (Komárek et al., 2013), Okeania (Engene et al., 2013), Microseira (McGregor and Sendall, 2015), and Dapis (Engene et al., 2018)] so it is likely that the current nomenclature of Lyngbya and Microseira species identified from Florida fresh and marine waters will be revised.

Marine Lyngbya can produce over 70 different toxins (Harr et al., 2008) that are irritants to eyes, skin and the respiratory system, as well as neuroparalytic and cytotoxic compounds (Osborne et al., 2001; Shimizu, 2003; Capper et al., 2013). Foss et al. (2012) reported the presence of PSTs decarbamoylgonyautoxin 2\&3 (dcGTX2\&3) and decarbamoylsaxitoxin (dcSTX) in M. wollei mats in Florida springs as well as evidence supporting the presence of all M. wollei toxins (LWT 1-6) and Berry et al. (2004) reported that Lyngbya sp. isolated from the Everglades contains pahayokolide A. While there is evidence that marine Lyngbya in Florida coastal waters is less toxic other marine Lyngbya's globally (e.g., Australia, Dennison et al., 1999), Metcalf et al. (2021) recent report of BMAA production from Lyngbya populations in Sarasota Bay suggests that this assumption should be reassessed.

\section{Trichodesmium Species}

Trichodesmium is a pelagic marine cyanobacterial genus that occurs worldwide in oligotrophic tropical and subtropical waters (Capone et al., 1997). Within the eastern GoM, Trichodesmium can form extensive surface blooms in early spring through the fall (Lenes and Heil, 2010), which resemble sawdust on the ocean surface (hence its nickname 'sea sawdust'). This genus is colonial, with cells joined in long filaments called trichomes, which can group together into macroscopic (up to $1 \mathrm{~cm}$ ) 'tuft' or 'puff' forms (Capone et al., 1997). Cells regulate their buoyancy, often forming surface populations dense enough to be detected by satellite ( $\mathrm{Hu}$ et al., 2010; Hu and Feng, 2014). These blooms infrequently impinge upon west Florida beaches, where they are mistaken for sewage spills due to their brown coloring.

Trichodesmium is an important component of biogeochemical nutrient cycling within the ocean, including the GoM. Trichodesmium is a diazotroph and utilizes a specialized Fe-requiring enzyme called nitrogenase to 'fix' atmospheric $\mathrm{N}_{2}$ gas into $\mathrm{NH}_{4}{ }^{+}$. The scale of $\mathrm{N}_{2}$ fixation by Trichodesmium is globally significant (Carpenter and Capone, 1992); it is estimated to account for up to $50 \%$ of the $\mathrm{N}$ fixed globally in marine systems, between 60 and $80 \mathrm{Tg}$ of $\mathrm{N}$ per year (Bergman et al., 2013). Although globally some strains of Trichodesmium can produce toxins (Hawser et al., 1992; Kerbrat et al., 2011; Detoni et al., 2016). While not directly toxic, Trichodesmium has been implicated as an important nutrient source for offshore initiation stages of K. brevis blooms (see “K. brevis" section).

\section{Other Florida Nuisance HAB Species Macroalgal HABs ("Drift Algae," "Red Drift Algae," and "Golden Tides")}

Large floating mats of a variety of macroalgal genera (e.g., Gracilaria, Hypnea, Botryocladia, Eucheuma, Sargassum) have long been recognized to provide critical habitats to a variety of estuarine and marine biota in Florida (Thorhaug and Roessler, 1977; Gore et al., 1981). Recent large accumulations of these macroalgal mats, popularly known as 'drift algae' or 'red drift algae' have, however, become increasingly problematic in Florida estuarine and coastal marine waters. Many species of macroalgae respond to increasing nutrient supply by increasing their biomass (Lapointe et al., 1994; Morand and Briand, 1996; Valiela et al., 1997). Early reports of drift algae accumulations of Gracilaria and Ulva spp. in Tampa Bay from the 1960's to the early 1980's were attributed to eutrophication within the Bay (Humm, 1973; Guist and Humm, 1976; Avery, 1997). In 2003-2004, Lee County beaches in southwest Florida began to experience large Rhodophyte blooms which washed ashore on beaches in large quantities which was attributed to local increases in nutrient inputs (Lapointe and Bedford, 2007). While not directly toxic, these mats resulted in a variety of environmental problems including dissolved oxygen depletion, displaced species, habitat destruction, increases in arsenic and fecal coliform counts, changes in biogeochemical cycling and seagrass and coral dieoffs (Lapointe et al., 1994, 2020; McGlathery, 1995; Valiela et al., 1997; Board and National Research Council, 2000). Large macroalgal accumulations on beaches result in unpleasant odors and are aesthetically displeasing to beachgoers, negatively impacting tourism and incurring significant costs by local municipalities for their repeated physical removal (Morand and Briand, 1996; Lapointe and Thacker, 2001). Their continuing annual reappearance on beaches in south Florida during summer months suggests that they have become an ongoing 
environmental problem. Although the effects of climate change on drift algae is unknown, it is likely that increasing temperatures and coastal nutrient inputs may increase the frequency and spread of the phenomena north and southward from the tropics. This may indirectly impact the spread of other HAB species as Besada and Loeblich (1982) and Bomber et al., 1988a,b suggest that these drift algal mats may also play a role in the circumtropical dispersal and spread of ciguatera dinoflagellates in the region by providing a drifting substrate of epiphytic ciguatera causing dinoflagellates.

The macroalgal genus Sargassum has become particularly problematic in the Caribbean Sea and southern Florida coastal region since 2011 (Franks et al., 2011; van Tussenbroek, 2011; Smetacek and Zingone, 2013), forming massive blooms termed "golden tides" (Smetacek and Zingone, 2013) for their goldcolored pigments. Wang et al. (2019) described the great Atlantic Sargassum belt, a $8,850 \mathrm{~km}$ area of Sargassum extending from the African coast to the GoM that has been reoccurring since 2011, and which in 2018 contained more than 20 million metric tons of biomass with significant associated environmental and economic issues. Although the causes and dynamics of the belt are not well understood, Wang et al. (2019) hypothesize that it is supported by nutrients derived from west African coastal upwelling in the winter, and Amazon River discharge in the spring and summer. Johns et al. (2020) analysis of drifter groundings demonstrated that Sargassum present in this belt from 2011 to 2012 was transported into the GoM to the Florida Keys. Sargassum was particularly problematic in 2018, when large Sargassum masses drifted onto Miami's beaches.

\section{Ecosystem Disruptive Algal Bloom (EDAB) Species}

Since 2012, 'super blooms' of the brown tide pelagophyte Aureoumbra lagunensis have occurred in the IRL, a narrow, shallow, poorly flushed (Smith, 1993) $240 \mathrm{~km}$ long estuary on Florida's east coast (Gobler et al., 2013; Kang et al., 2015; Lapointe et al., 2015, 2017; Judice et al., 2020). Although not toxic, these blooms are an example of an ecosystem disruption algal bloom (EDAB, Sunda et al., 2006; Gobler and Sunda, 2012), or an algal bloom which significantly alters or degrades ecosystem function. Aureoumbra lagunensis is a small $(2-5 \mu \mathrm{m})$, non-descript (Koch et al., 2014) phytoplankton that contains the accessory pigment fucoxanthin (DeYoe et al., 1997) and reaches sufficiently high concentrations $\left(200 \mu \mathrm{g} \mathrm{L}^{-1} \mathrm{Chl} a,>10^{6}\right.$ cells L $^{-1}$ in the 2012 IRL bloom, Gobler et al., 2013) to attenuate light, resulting in seagrass loss. High cell concentrations in the 2012 IRL bloom resulted in finfish and shellfish kills due to the bloom-induced near hypoxic conditions resulting in a decline of these organisms and/or reductions in shellfish clearance rates (Gobler et al., 2013).

Aureoumbra lagunensis blooms have been a recurring feature of the Laguna Madre and Baffin Bay in Texas for more than 20 years (Buskey and Hyatt, 1995; Buskey et al., 1998; Buskey et al., 2001; Villareal et al., 2004) prior to their spread to the IRL in 2012 (Gobler et al., 2013) and Cuba in 2013 (Koch et al., 2014; Hall et al., 2018). This species is resilient in hypersaline conditions (Buskey et al., 1998; Liu and Buskey, 2000) and outcompetes phytoplankton under conditions of reduced $\mathrm{N}$, especially dissolved organic N, low P (Kang et al., 2015) and high N:P ratios (Liu et al., 2001). The IRL is hypereutrophic (Bricker et al., 2007), with nutrient inputs shifting from pointsource dominance in the 1980's to non-point source inputs such as sewage enriched in reduced $\mathrm{N}$ forms (Virnstein and Carbonara, 1985; Barile and LaPointe, 1999; Barile, 2018). This species has been shown to preferentially take up $\mathrm{NH}_{4}{ }^{+}$and urea in the IRL where the bloom was characterized by lower $\delta^{15} \mathrm{~N}$ stable isotope values, suggesting support by regenerated $\mathrm{N}$ compounds (Kang et al., 2015). Nutrient enrichment alone may not explain the dominance of A. lagunensis in the IRL, however. Grazing avoidance has also been demonstrated for A. lagunensis in the IRL (Kang et al., 2015) as has allelopathy (Kang and Gobler, 2018). A resting stage has also been documented for A. lagunensis (Kang et al., 2017), which may allow this species to avoid adverse environmental conditions as well as facilitate the spread of these blooms.

\section{CLIMATE CHANGE AND FLORIDA HABS}

Climate change represents the ultimate anthropogenic stressor in Florida. Levels of $p \mathrm{CO}_{2}$ have risen from pre-industrial age levels of $280 \pm 10 \mathrm{ppm}$ to current levels of over $400 \mathrm{ppm}$, largely due to fossil fuel burning and deforestation (Pörtner et al., 2019). Climate change is undoubtedly influencing aquatic systems worldwide in many nuanced, complex and interacting ways, resulting in increasing water temperatures, lower $\mathrm{pH}$, changes in vertical mixing, stratification and upwelling, as well as changes in storm intensities and freshwater inputs (McMichael et al., 2006; Patz et al., 2006; Laws, 2007). How climate change is potentially influencing $\mathrm{HABs}$ globally is an important issue and poses many challenges to resource managers, but has only recently received significant scientific examination (Geesey and Tester, 1993; Hallegraeff, 1993, 2010; Tester, 1993; Wells et al., 2015; Gobler, 2020; Yan et al., 2020 and references therein). One reason for the lack of research has been the difficulty in differentiating the effects of climate change on HABs from other anthropogenic stressors (e.g., eutrophication, ballast water introductions, Moore et al., 2008). Tester and co-authors suggested potential impacts of climate change on the Florida red tide dinoflagellate K. brevis in the early 1990's (Tester, 1993) and scientists have increasingly linked a variety of both freshwater and marine HABs to climate change globally (Dale et al., 2006; Edwards et al., 2006; Moore et al., 2008; Paerl and Huisman, 2008; Hallegraeff, 2010; O’Neil et al., 2012; Glibert et al., 2014; Havens and Paerl, 2015; Wells et al., 2015; Gobler, 2020 and articles contained within). However, only in 2019 have HABs been directly linked to climate change by the United Nations' Intergovernmental Panel on Climate Change's (IPCC) Special Report on the Ocean and Cryosphere in a Changing Climate (Pörtner et al., 2019). The links between climate change and $\mathrm{HABs}$ are explored in a recent special issue of the journal Harmful Algae (see Gobler, 2020 and references within).

Florida is considered especially susceptible to the impacts of climate change (Obeysekera et al., 2011), with its warmer, nutrient rich waters. Eight of the 10 cities in the United States identified as most susceptible to climate change costs are in 
Florida (Muro et al., 2019). Generalized as warming, acidification and deoxygenation (Gobler, 2020), the specific climate change impacts likely to impact Florida include sea-level rise (Reece et al., 2013), increasingly intense weather and heavy precipitation events (Knutson et al., 2010; Emanuel, 2013; Contento et al., 2018, 2019; Marsooli et al., 2019), marine fishery declines (Cheung et al., 2009), water pollution (Moss et al., 2011; Glibert, 2020), and reef and habitat loss (Snedaker, 1995; Manzello et al., 2007; Tobey et al., 2010; Okazaki et al., 2017). There is a general consensus that climate change is predicted to increase the frequency of both freshwater (O'Neil et al., 2012; Havens and Paerl, 2015) and marine HABs (Hallegraeff, 2010) through a variety of direct and indirect mechanisms. The impacts of climate change on Florida HABs are likely to vary with species involved, and range from direct impacts at the cellular level (e.g., cell metabolism) to regional impacts on spatial and temporal range expansions. Additionally, indirect effects of climatic associated changes, such as the impacts of changing hurricane intensities on local rainfall and runoff, may supply additional nutrients to blooms or alter the physical characteristics of the water column through increasing stratification. At the same time, alterations in food webs and nutrient cycling and trophic interactions resulting from changing temperatures and $\mathrm{CO}_{2}$ levels add additional layers of complexity to both studying and predicting the impacts of climate change on HABs.

Climate change has been predicted to impact HABs in Florida in a number of ways. Warming waters may act to expand the geographical range and bloom duration of some $\mathrm{HAB}$ species, pushing tropical and subtropical species northward and extending their bloom seasons. This was suggested as a potential impact for both GoM K. brevis blooms by Tester (1993) as well as for ciguatera dinoflagellates (Tester et al., 2010). Transport of $K$. brevis blooms from southwest Florida to the east coast of Florida has frequently occurred (Tester and Steidinger, 1997) with subsequent transport as far north as North Carolina in 1986 (Tester et al., 1991) where the bloom persisted for 4-5 months and resulted in closures of shellfish harvesting areas with an estimated \$25 million loss (Tester and Fowler, 1990). Unlike K. brevis, most of the 11 other Karenia species present in the Gulf [e.g., Karenia mikimotoi, Karenia papilionaceae, Karenia selliformis, Karenia umbella (Steidinger et al., 2018)] have a widespread distribution globally, suggesting that the potential exists for an increase in their occurrence in the GoM. Within the United Kingdom, K. mikimotoi has spread northward, possibly due to change in the timing of stratification (Davidson et al., 2009; Bresnan et al., 2013; Townhill et al., 2018) and Turner et al. (2015) suggest that warming waters may favor other Karenia species in United Kingdom waters. Ciguatera dinoflagellates may be especially responsive to increasing water temperatures. A correlation between abundance of the ciguatera dinoflagellate G. toxicus and increased sea surface temperatures during El Niño has been reported for the south Pacific (Hales et al., 1999; Chateau-Degat et al., 2005), where ciguatera has been recognized to be spreading since the 1970's (Maclean, 1989; Hallegraeff, 1993). Villareal et al. (2007) documented how the prevalence of offshore oil rigs in the GoM has allowed the expansion of ciguatera dinoflagellates northward by providing substrate. Although Florida does not have oil rigs within its coastal waters, Villareal et al. (2007)'s documentation of G. toxicus associated with Sargassum, which is increasing in abundance in both the Atlantic Ocean and the GoM (Dierssen et al., 2015; Wang et al., 2019), suggests that other vectors for transport of ciguatera dinoflagellates northward in Florida waters exist. Warmer waters may also influence the spread of ciguatera indirectly through impacts on the coral substrate itself. Ciguatera has been noted to increase in tropical and subtropical regions where reef systems have experienced some form of anthropogenic disturbance, such as physical reef destruction due to storm damage or coral bleaching due to rising temperatures (Skinner et al., 2011; Rongo and van Woesik, 2013). Reef destruction can lead to increasing microalgal colonization, providing additional substrate for benthic dinoflagellate species, including G. toxicus. In south Florida, ongoing degradation of the Florida Key reef tract (Kemp et al., 2011; Colella et al., 2012; Lapointe et al., 2020) and southeast Florida reefs (Lapointe, 1997) with increasing associated macroalgal colonization has been well documented.

Climate change has been cited as one of the factors contributing to the increase in cyanoHABs globally (Paerl and Huisman, 2008; O'Neil et al., 2012; Paerl and Paul, 2012; Yan et al., 2020) as well as within Florida (Paerl and Huisman, 2008; Havens and Paerl, 2015; Urquhart et al., 2017; Havens et al., 2019). Climate change influences cyanobacteria directly through temperature effects on metabolism as well as environmentally through impacts on the physical and chemical characteristics of the cyanoHABs environment. Cyanobacteria have a higher temperature optimum for growth than do eukaryotes (Paerl and Huisman, 2008), suggesting that they have a competitive advantage over other algae as temperatures increase. A relationship between water temperature and cyanobacterial dominance has been noted for many systems (de Figueiredo et al., 2006; Paerl et al., 2011). Carey et al. (2012) suggested that there are many other physiological advantages that favor cyanobacteria to effectively outcompete other algae under warming conditions, including buoyancy, $\mathrm{P}$ storage affinity, atmospheric $\mathrm{N}_{2}$ fixation and efficient light harvesting ability. The increases in rainfall and frequency of extreme rainfall events predicted to result from climate change (Groisman et al., 2012) may also favor cyanobacteria through increased $\mathrm{N}$ and $\mathrm{P}$ nutrient loading to freshwaters, as well as changes in the quality and quantity of this loading, the volume ratio of inputs to receiving waters and its seasonal timing (Reichwaldt and Ghadouani, 2012). Additionally, increasing temperatures have a direct effect upon the physical characteristics of freshwater systems, resulting in earlier (Winder and Schindler, 2004) and stronger stratification and reducing vertical mixing ( $\mathrm{Xu}$ et al., 2010) and longer residence times (Lehman et al., 2013; Cross et al., 2014). This may lead to potential oxygen depletion at depth and $\mathrm{P}$ enrichment from sediments, thus enhancing nutrient recycling (Søndergaard et al., 2003; Wilhelm and Adrian, 2008). The net effect of these climate change associated changes in freshwater systems, including those in Florida, is favoring of cyanobacteria over other algae.

Many HAB species, especially dinoflagellates, have life cycles characterized by benthic resting stages or cysts, stages that allow 
a species to survive adverse environmental conditions. Within Florida, both $P$. bahamense and A. lagunensis have resting stages. Cysts of $P$. bahamense have a much broader global geographic distribution than do vegetative cells of this species (Zonneveld et al., 2013; Brosnahan et al., 2020), suggesting that there are many areas globally, and within Florida, that currently do not experience $P$. bahamense blooms but may be primed to do so by the presence of cyst beds. Cyst beds of $P$. bahamense have been documented from the Indian River Lagoon, Tampa Bay and in Charlotte Harbor (Phlips et al., 2006), with highest vegetative cell concentrations occurring in the area where resting cysts are concentrated ( $>10^{3}$ cysts gm wet weight ${ }^{-1}$ of sediments) in Tampa Bay (Lopez et al., 2015). Concentrations of 300-900 cysts gm wet weight ${ }^{-1}$ of sediments have been reported from the IRL (Brosnahan et al., 2020). The environmental conditions under which $P$. bahamense resting cysts are produced and excyst in Florida populations is unknown. Brosnahan et al. (2020) suggests that as warming changes species ranges, cyst beds may persist longer in shallow nearshore areas that exhibit more seasonally variable temperatures, contributing to the potential for increasing $P$. bahamense blooms and associated PSP or SPFP events northward within Florida as warming occurs. Florida state HAB monitoring data suggest that currently a bloom maximum of $10^{6}$ cells $\mathrm{L}^{-1}$ of $P$. bahamense exists within Florida waters (Brosnahan et al., 2020).

An additional indirect impact of climate change is ocean acidification. As $\mathrm{pCO}_{2}$ concentrations rise in the atmosphere, increasing $\mathrm{CO}_{2}$ concentrations dissolve in seawater. $\mathrm{CO}_{2}$ in seawater dissolves to form carbonate species which disassociate and produce hydrogen ions, leading to a decrease in the $\mathrm{pH}$ of seawater, termed ocean acidification (OA). Changes in $\mathrm{pH}$ can influence both growth and toxicity in some HAB species (Griffith and Gobler, 2020). Several early studies of natural systems (Yoo, 1991) and natural populations within mesocosms (Hinga, 1992) report a positive correlation between $\mathrm{pH}$ and dinoflagellate abundance. Although this is counter-intuitive to an increase in $\mathrm{HABs}$ resulting from the decreasing $\mathrm{pH}$ associated with OA, the relationship does not hold for diatoms (Hinga, 2002) and there are significant clonal and species differences in the dinoflagellate responses (Hinga, 2002). Under low $\mathrm{pH}$ and high $\mathrm{pCO}_{2}$ concentrations, Pseudo-nitzschia multiseries (Hasle) Hasle increases domoic acid production (Sun et al., 2011; Tatters et al., 2012), although this has been shown to be strain specific with some producing domoic acid under high $\mathrm{pH}$ conditions (Lundholm et al., 2004; Trimborn et al., 2008). Reported effects of increasing $\mathrm{pCO}_{2}$ on $K$. brevis are somewhat contradictory. Errera et al. (2014) reported higher growth rates at higher $p \mathrm{CO}_{2}$ concentrations, but did not find any relationship between toxin concentrations and either temperature or $\mathrm{pCO}_{2}$ concentrations. In contrast, Hardison et al. (2014) reported reduced growth and enhanced toxicity under reduced $\mathrm{pCO}_{2}$ concentrations. Bercel and Kranz (2019) however, did not find a significant response in growth, cellular carbon and $\mathrm{N}$ quotas, nor in photosynthetic rates over a $\mathrm{pCO}_{2}$ concentration range from 150 to $780 \mu \mathrm{atm}$. They reported no statistically significant, correlation between $\mathrm{pCO}_{2}$ and brevetoxin content, but a strong effect on $K$. brevis acquisition of inorganic carbon, with an increase in half saturation values for $\mathrm{CO}_{2}$ (from 1.5 to $3.3 \mu \mathrm{M}$ ), a switch in inorganic carbon preference from $\mathrm{HCO}_{3}$ - to $\mathrm{CO}_{2}$, and downregulation of external carbonic anhydrase activity. They concluded that $K$. brevis employs an efficiently regulated carbon concentration mechanism to maintain constant carbon fixation and growth across $\mathrm{pCO}_{2}$ levels. Although Bercel and Kranz (2019) conclude that net photosynthesis of K. brevis is not impacted by $p \mathrm{CO}_{2}$, the work of Errera et al. (2014) and Hardison et al. (2014) suggests that at the very least there are significant clonal differences in $K$. brevis response to $\mathrm{pH}$ and $p \mathrm{CO}_{2}$ concentrations which require further study before a reasonably assured prediction can be made of the impacts of changing $p \mathrm{CO}_{2}$ and $\mathrm{pH}$ can be made for $K$. brevis blooms.

Climate change impacts $\mathrm{HAB}$ species on spatial scales ranging from subcellular metabolism to oceanic gyres and on temporal scales from nanosceconds to decades. These large and variable scales involved as well as complex trophic interactions and feedbacks make predicting the response of Florida HABs to climate change problematic. While the conclusions that climate change will result in $\mathrm{HAB}$ range expansion and increased frequency, changes in abundances and seasonal growth windows and secondary effects for marine food webs (Hallegraeff, 2010) are generally agreed upon by scientists, extensive strain- and strain-specific responses, dynamic interactions between species as well as non-linear responses in $\mathrm{HAB}$ growth and toxin production to climate related stressors (Griffith and Gobler, 2020) suggest that predicting these impacts is currently problematic and presents an immense challenge for $\mathrm{HAB}$ researchers, monitoring programs and managers.

\section{FUTURE CHALLENGES ASSOCIATED WITH FLORIDA HABS AND HAB RISK MANAGEMENT}

There are many unknowns regarding HABs in Florida, the most immediate of which are those related to human health risks. Transfer of algal toxins to humans via consumption (e.g., contaminated shellfish) is well documented for many toxins, but emphasis has been on acute health impacts of exposure. The chronic impacts and health risks associated with low level toxin exposures in shellfish and finfish are unknown. With the increasing importance of seafood in diets (Love et al., 2020), this exposure route is predicted to become increasingly important. This is especially important for new and emerging toxins, such as the cyanobacterial toxin BMAA. Little is known of the environmental and physiological factors influencing its production, transfer through aquatic food webs, route(s) of transmission to humans and clinical impacts and biomarkers of exposure. Study of potentially important toxin transfer routes, such as aerosolization of brevetoxins and cyanobacterial toxins, are in their infancy. Study of these routes is especially important given the increase in freshwater cyanobacterial blooms in Florida, and the transport of these blooms and associated toxins to estuarine and marine waters (Preece et al., 2017), such as occurred in 2018 when the Lake Okeechobee Microcystis bloom was released down the St. Lucie and Caloosahatchee Rivers. 
Harmful Algal Blooms species other than those described in the text above have been noted or bloomed within Florida waters, including some with known toxins. An example is the dinoflagellate Peridinium quinquecorne T.H. Abé, which has bloomed in coastal areas with restricted circulation and elevated nutrient inputs, resulting in localized anoxia. Although these blooms are often viewed as isolated events, with Florida's ongoing anthropogenic stressors, including changing demographics, coastal development, eutrophication and climate change impacts, conditions may be changing in such a manner as to potentially make environmental conditions more favorable for $\mathrm{HAB}$ species in Florida waters in the future. Toxicity is variable in some $\mathrm{HAB}$ species, but has also been shown to vary with nutrient supply as well as environmental conditions [e.g., Pseudo-nitzschia spp. (Tatters et al., 2012), K. brevis (Hardison et al., 2012; Hardison et al., 2013)] and thus is also potentially impacted by changing conditions. Indirect impacts of current HABs, e.g., altered food webs, may potentially contribute to new HAB occurrences. New HABs may also occur through the promotion of species present in the "hidden" plankton (Steidinger et al., 2018), through invasive species brought to Florida waters by currents or from ballast water or sediment introductions. The 'unknown HAB', an unidentified bloom forming species or one that has yet to present itself as a threat due to unidentified toxicity, is impossible to predict and remains a major challenge for management and monitoring agencies. Perhaps the best example of this to date in Florida is the appearance of toxicity associated with $P$. bahamense in the Indian River Lagoon, where it had never previously been noted for this species in the Atlantic.

Ascribing different HABs to causative or contributing anthropogenic and natural stressors and identifying and developing appropriate mitigation strategies to address these stressors and curb their impacts require establishing trends in bloom frequency, magnitude and duration, which in turn, requires a timeline of relevant measurements, collected in a statistically valid manner. Given their often episodic occurrence and the event response nature of HAB monitoring, these types of long term data sets are rarely available for HABs. Bloom history can be recorded in sediment cores if a suitable proxy for the $\mathrm{HAB}$ of interest is available. In Florida's estuarine and marine systems, which are generally characterized by nondepositional carbonate or limestone sediments or subjected to extensive reworking due to anthropogenic activities, establishing this sedimentary record is especially problematic. Turner et al. (2006) examined the sedimentary record from Charlotte Harbor and found a threefold increase in $\mathrm{N}$ loading to the estuary over the past 200 years. Increased carbon loading from the $\mathrm{N}$-limited phytoplankton has resulted in increasingly anoxic bottom sediments as a result. However, a more detailed analysis of total phosphorus (TP), total $\mathrm{N}$ (TN), and $\mathrm{NO}_{3}{ }^{-}$and $\mathrm{PO}_{4}$ at the mouth of the Caloosahatchee River (Anderson et al., 2008) from 1949 to 2005 clearly shows the influence of shifting state agricultural trends (e.g., the shift to sugar agriculture in southwest Florida post Cuban Revolution) as well as municipal and federal laws restricting or banning $\mathrm{P}$ in detergents from the 1970's onward (ReVelle and ReVelle, 1988) on shorter time periods.
Although a long-term record exists for $K$. brevis blooms in Florida and has been used to argue a link between a potential trend in increasing frequency and coastal eutrophication (Brand and Compton, 2007), the database upon which the argument is based was compiled in 2000 (Haverkamp et al., 2004) and consists of records of $K$. brevis cell concentrations compiled from $>70$ entities, with water samples collected at irregular intervals over variable time and spatial scales, often in event response mode. This makes statistical analysis of this database extremely problematic (Steidinger, 2009; Heil et al., 2014a). It is only with an established monitoring program of stations sampled at regular intervals during both bloom and non-bloom conditions that statistically valid conclusions may be drawn.

As stated previously, the ongoing, continual immigration of people into Florida translates into more potential HAB exposures from current known HABs. As more people move to Florida, whether for economic reasons or for access to Florida's rich coastal resources, more people are potentially exposed to existing HABs and their toxins. Florida's economy is heavily reliant on tourism, and much of this tourism is focused on the coastal environment, including clean beaches and available resources. This lack of public knowledge of HABs may be especially dangerous in a state in which a high percentage of the population is transient, e.g., tourists with stays of limited duration, with little knowledge of HABs, their potential impacts or how to avoid exposure. Regardless of long-term HAB trends, the demographics of Florida populations suggest that more people are experiencing and being exposed to these blooms than ever before.

Within Florida, demographic, developmental and environmental changes have been ongoing for over 100 years. These continual changes make establishing a realistic predevelopment baseline for both water quality and HABs problematic, which in turn may give false impressions of past environmental conditions surrounding HABs, making it difficult for policy makers and environmental managers to set appropriate restoration and management guidelines. This difficulty in establishing a water quality and $\mathrm{HAB}$ baseline is similar to the concept of a 'shifting baseline', originally proposed by Pauly (1995). Developed to explain the inability of fisheries scientists to incorporate historical fisheries data to be used as a reference point between generations of fisheries scientists, and the tendency for scientists to use inappropriate reference points as a baseline for the state of the science at the beginning of their careers, the concept has been expanded into the shifting baseline syndrome (SBS) and applied to many other disciples [e.g., ethnobotany (Hanazaki et al., 2013), habitat loss (Humphries and Winemiller, 2009), pollution (Lyytimäki, 2013), and climate change (Herman-Mercer et al., 2016)]. It describes a gradient change in the accepted environmental 'norm' over time due to lack of experience, memory or knowledge (Soga and Gaston, 2018) and how people can falsely perceive environmental change over time. The concept is readily applicable to the perception of environmental change and HABs in Florida, especially both in assessing long-term changes in HABs over time as well as their relationship to climate change and degrading water quality. As an example, new Florida resident's experience of $K$. brevis blooms date to their first experience, which with recent immigrants, is 
the severe 2017-2019 K. brevis bloom which lasted for 17 months and resulted in extensive respiratory irritation, fish kills and marine seabird and mammal mortalities. The perception of this bloom as the 'status quo' for red tides has tempered public responses to the bloom itself as well as subsequent blooms and management practices (e.g., management related Lake Okeechobee releases) perceived to have influenced this bloom.

Recent studies on media exposure, risk perceptions and visitor behavioral responses (e.g., Cahyanto and Liu-Lastres, 2020) has underscored the need for effective outreach to visitors and residents alike regarding risks associated with HABs in Florida. Indeed, knowledge of Florida red tide was found to be widely inconsistent and incorrect (Nierenberg et al., 2010) with the media framing red tide as a largely environmental issue ( $\mathrm{Li}$ et al., 2015). Advances in knowledge of $\mathrm{HAB}$ human health impacts and mitigation have not been effectively communicated to the public and the risk perception regarding shellfish consumption during red tides has declined (Kuhar et al., 2009; Kirkpatrick et al., 2014). In some cases, both risk perceptions and misconceptions have been socially amplified, which has been identified as a contributor to many Florida Red Tide messaging issues (Kuhar et al., 2009; Nierenberg et al., 2010). Social media undoubtedly plays a role in risk perception and social amplification regarding misconceptions with regards to HABS in Florida, but has not been assessed. Targeted messaging and unique products developed early in projects and utilizing appropriate media

\section{REFERENCES}

Abbott, J. P., Flewelling, L. J., and Landsberg, J. H. (2009). Saxitoxin monitoring in three species of Florida puffer fish. Harmful Algae 8, 343-348. doi: 10.1016/j. hal.2008.07.005

Abraham, A., Flewelling, L. J., El Said, K. R., Odom, W., Geiger, S. P., Granholm, A. A., et al. (2021). An occurrence of neurotoxic shellfish poisoning by consumption of gastropods contaminated with brevetoxins. Toxicon 191, 9-17. doi: 10.1016/j.toxicon.2020.12.010

Accoroni, S., Totti, C., Romagnoli, T., Giulietti, S., and Glibert, P. M. (2020). Distribution and potential toxicity of benthic harmful dinoflagellates in waters of Florida Bay and the Florida Keys. Mar. Environ. Res. 155:104891. doi: 10. 1016/j.marenvres.2020.104891

Adachi, R., and Fukuyo, Y. (1979). The thecal structure of a marine toxic dinoflagellate Gambierdiscus toxicus gen. et sp. nov. collected in a ciguateraendemic area. Bull. Jpn. Soc. Sci. Fish 45, 67-71. doi: 10.2331/suisan.45.67

Adams, C. M., Larkin, S. L., Hoagland, P., and Sancewich, B. (2018). "Assessing the economic consequences of harmful algal blooms: a summary of existing literature, research methods, data, and information gaps," in Harmful Algal Blooms: A Compendium Desk Reference, eds S. E. Shumway, J. M. Burkholder, and S. L. Morton (Hoboken, NJ: John Wiley \& Sons, Ltd). doi: 10.1002/ 9781118994672.ch8

Adams, C. M., Mulkey, D., Hodges, A., and Milon, J. (2000). Development of an Economic Impact Assessment Methodology for Occurrence of Red Tide. SP 00-12. Gainesville, FL: University of Florida.

Adams, C., Larkin, S., Mulkey, D., and Hodges, A. (2002). Measuring the Economic Consequences and Public Awareness of Red Tide Events in Florida. Harmful Algal Task Force, Florida Marine Research Institute. St. Petersburg, FL: Florida Marine Research Institute.

Ahmed, F. E. (1991). Naturally occurring seafood toxins. J. Toxicol. Toxin Rev. 10, 263-287. doi: 10.3109/15569549109053858

Anderson, D. M. (1989). “Toxic algal blooms and red tides: a global perspective," in Red Tides: Biology, Environmental Science and Toxicology, for the targeted stakeholders has been shown to be an effective communication strategy for HABs (Nierenberg et al., 2011). However, effective communication of HAB associated human health, environmental and economic risks in Florida remains challenging.

\section{AUTHOR CONTRIBUTIONS}

All authors listed have made a substantial, direct and intellectual contribution to the work, and approved it for publication.

\section{FUNDING}

Support was provided by grants from NOAA (NA19NOS4780183) and Florida Sea Grant (NA18OAR4170085), with additional salary support for $\mathrm{CAH}$ provided by the Economos and Barancik Foundations.

\section{ACKNOWLEDGMENTS}

The authors would like to acknowledge the staff of the Red Tide Institute, who generously gave their time so the authors could complete the manuscript and two reviewers whose thoughtful review and suggestions greatly improved the manuscript. This is ECOHAB Publication \#989.

eds T. Okaichi, D. M. Anderson, and T. Nemoto (New York, NY: Elsevier), 11-16.

Anderson, D. M. (2004). Prevention, Control and Mitigation of Harmful Algal Blooms: Multiple Approaches to HAB Management, Harmful Algae Management and Mitigation. APEC Publication \#204-MR-04.2, eds S. Hall, S. Etheridge, D. Anderson, J. Kleindinst, M. Zhu, and Y. Zou (Singapore: Pacific Economic Cooperation), 177-181.

Anderson, D. M., Burkholder, J. M., Cochlan, W. P., Glibert, P. M., Gobler, C. J., Heil, et al. (2008). Harmful algal blooms and eutrophication: examining linkages from selected coastal regions of the United States. Harmful Algae 8, 39-53. doi: 10.1016/j.hal.2008. 08.017

Anderson, D. M., Cembella, A. D., and Hallegraeff, G. M. (2012). Progress in understanding harmful algal blooms: paradigm shifts and new technologies for research, monitoring, and management. Annu. Rev. Mar. Sci. 4, 143-176. doi: 10.1146/annurev-marine-120308-081121

Anderson, D. M., Fensin, E., Gobler, C. J., Hoeglund, A. E., Hubbard, K. A., Kulis, D. M., et al. (2021). Marine harmful algal blooms (HABs) in the United States: history, current status and future trends. Harmful Algae 102:101975. doi: 10. 1016/j.hal.2021.101975

Anderson, D. M., Glibert, P. M., and Burkholder, J. M. (2002). Harmful algal blooms and eutrophication: nutrient sources, composition, and consequences. Estuaries 25, 704-726. doi: 10.1007/bf02804901

Anderson, D. M., Hoagland, P., Kaoru, Y., and White, A. W. (2000). Estimated Annual Economic Impacts from Harmful Algal Blooms (HABs) in the United States". Norman, OK: National Oceanic and Atmospheric Administration.

Avery, W. (1997). "Distribution and abundance of macroalgae and seagrass in Hillsborough Bay, Florida, from 1986 to 1995," in Proceedings, Tampa Bay Area Scientific Information Symposium, St. Petersburg, FL, 151-165.

Azevedo, S. M., Carmichael, W. W., Jochimsen, E. M., Rinehart, K. L., Lau, S., Shaw, G. R., et al. (2002). Human intoxication by microcystins during renal 
dialysis treatment in Caruaru-Brazil. Toxicology 181, 441-446. doi: 10.1016/ s0300-483x(02)00491-2

Azziz-Baumgartner, E., Luber, G., Conklin, L., Tosteson, T. R., Granade, H. R., Dickey, R. W., et al. (2012). Assessing the incidence of ciguatera fish poisoning with two surveys conducted in Culebra, Puerto Rico, during 2005 and 2006. Environ. Health Perspect. 120, 526-529. doi: 10.1289/ehp.1104003

Babinchak, J. A., Jollow, D. J., Voegtline, M. S., and Higerd, T. B. (1986). Toxin production by Gambierdiscus toxicus isolated from the Florida Keys. Mar. Fish. Rev. 48, 53-56.

Backer, L. C., Carmichael, W., Kirkpatrick, B., Williams, C., Irvin, M., Zhou, Y., et al. (2008). Recreational exposure to low concentrations of microcystins during an algal bloom in a small lake. Mar. Drugs 6, 389-406. doi: 10.3390/ md6020389

Backer, L. C., Fleming, L. E., Rowan, A., Cheng, Y.-S., Benson, J., Pierce, R. H., et al. (2003). Recreational exposure to aerosolized brevetoxins during Florida red tide events. Harmful Algae 2, 19-28. doi: 10.1016/S1568-9883(03) 00005-2

Backer, L. C., McNeel, S. V., Barber, T., Kirkpatrick, B., Williams, C., Irvin, M., et al. (2010). Recreational exposure to microcystins during algal blooms in two California lakes. Toxicon 55, 909-921. doi: 10.1016/j.toxicon.2009. 07.006

Badylak, S., Kelley, K., and Phlips, E. J. (2004). A description of Pyrodinium bahamense (Dinophyceae) from the Indian River Lagoon, Florida, USA. Phycologia 43, 653-657. doi: 10.2216/i0031-8884-43-6-653.1

Badylak, S., and Phlips, E. J. (2004). Spatial and temporal patterns of phytoplankton composition in subtropical coastal lagoon, the Indian River Lagoon, Florida, USA. J. Plankton Res. 26, 1229-1247. doi: 10.1093/plankt/fbh114

Bagnis, R., Spiegel, A., Nguyen, L., and Plichart, R. (1992). "Public health, epidemiological and socioeconomic patterns of ciguatera in Tahiti," in Proceedings of the Third International Conference on Ciguatera Fish Poisoning: Polyscience Publications Quebec, Quebec, 131-143.

Balech, E. (1985). A revision of Pyrodinium bahamense Plate (Dinoflagellata). Rev. Palaeobot Palynol. 45, 17-34. doi: 10.1016/0034-6667(85)90063-6

Banack, S. A., Caller, T., Henegan, P., Haney, J., Murby, A., Metcalf, J. S., et al. (2015). Detection of cyanotoxins, $\beta-\mathrm{N}$-methylamino-L-alanine and microcystins, from a lake surrounded by cases of amyotrophic lateral sclerosis. Toxins 7, 322-336. doi: 10.3390/toxins7020322

Baratta, R. O., and Tanner, P. A. Jr. (1970). Ichthyosarcotoxism-Ciguatera intoxication. JFMA 57, 39-42.

Bargu, S., Baustian, M. M., Rabalais, N. N., Del Rio, R., Von Korff, B., and Turner, R. E. (2016). Influence of the Mississippi River on Pseudo-nitzschia spp. abundance and toxicity in Louisiana coastal waters. Estuaries Coasts 39, 1345-1356. doi: 10.1007/s12237-016-0088-y

Barile, P. J. (2018). Widespread sewage pollution of the Indian River Lagoon system, Florida (USA) resolved by spatial analyses of macroalgal biogeochemistry. Mar. Pollut. Bull. 128, 557-574. doi: 10.1016/j.marpolbul. 2018.01.046

Barile, P. J., and LaPointe, B. E. (1999). Estuaries in distress. Fla. Nat. 72, 26-28.

Barkin, R. M. (1974). Ciguatera poisoning: a common source outbreak. S. Med. J. 67, 13-16. doi: 10.1097/00007611-197401000-00005

Basti, L., Hégaret, H., and Shumway, S. E. (2018). "Harmful algal blooms and shellfish," in Harmful Algal Blooms: A Compendium Desk Reference, eds S. E. Shumway, J. M. Burkholder, and S. L. Morton (Hoboken, NJ: John Wiley \& Sons, Ltd), 135-190. doi: 10.1002/9781118994672.ch4

Bates, S. S., Garrison, D. L., and Horner, R. A. (1998). "Bloom dynamics and physiology of domoic-acid-producing Pseudo-nitzschia species," in Physiological ecology of harmful algal blooms, eds D. M. Anderson, A. D. Cembella, and G. M. Hallegraeff, (Heidelberg: Springer-Verlag), 267-292.

Bates, S. S., Hubbard, K. A., Lundholm, N., Montresor, M., and Leaw, C. P. (2018). Pseudo-nitzschia, Nitzschia, and domoic acid: new research since 2011. Harmful Algae 79, 3-43. doi: 10.1016/j.hal.2018.06.001

Bates, S., and Trainer, V. (2006). "The ecology of harmful diatoms," in Ecology of Harmful Algae, Ecological Studies (Analysis and Synthesis), Vol 189, eds E. Granéli and J. T. Turner (Berlin: Springer), 81-93. doi: 10.1007/978-3-54032210-8_7

Bates, S., Bird, C. J., Freitas, A. D., Foxall, R., Gilgan, M., Hanic, L. A., et al. (1989). Pennate diatom Nitzschia pungens as the primary source of domoic acid, a toxin in shellfish from eastern Prince Edward Island, Canada. Can. J. Fish. Aquat. Sci. 46, 1203-1215. doi: 10.1139/f89-156

Beardall, J., Stojkovic, S., and Larsen, S. (2009). Living in a high $\mathrm{CO}_{2}$ world: impacts of global climate change on marine phytoplankton. Plant Ecol. Divers. 2, 191-205. doi: 10.1080/17550870903271363

Bechard, A. (2019). Red tide at morning, tourists take warning? County-level economic effects of HABS on tourism dependent sectors. Harmful Algae 85:101689. doi: 10.1016/j.hal.2019.101689

Béchard, A. (2020a). Economics losses to fishery and seafood related businesses during harmful algal blooms. Fish. Res. 230:105678. doi: 10.1016/j.fishres.2020. 105678

Bechard, A. (2020b). Harmful algal blooms and tourism: the economic impact to Counties in Southwest Florida. Rev. Region. Stud. 50:2705.

Bechard, A. (2020c). External costs of harmful algal blooms using hedonic valuation: the impact of Karenia brevis on Southwest Florida. Environ. Sustain. Indic. 5:100019. doi: 10.1016/j.indic.2020.100019

Bechard, A. (2020d). The economic impacts of harmful algal blooms on tourism: an examination of Southwest Florida using a spline regression approach. Nat. Hazards 104, 593-609. doi: 10.1007/s11069-020-04182-7

Bechard, A. (2021). Gone with the wind: declines in property values as harmful algal blooms are blown towards the shore. J. Real Estate Finance Econ. 62, 242-257. doi: 10.1007/s11146-020-09749-6

Begier, E. M., Backer, L. C., Weisman, R. S., Hammond, R. M., Fleming, L. E., and Blythe, D. (2006). Outbreak bias in illness reporting and case confirmation in ciguatera fish poisoning surveillance in south Florida. Public Health Rep. 121, 658-665. doi: 10.1177/003335490612100605

Bejarano, A. C., VanDola, F. M., Gulland, F. M., Rowles, T. K., and Schwacke, L. H. (2008). Production and toxicity of the marine biotoxin domoic acid and its effects on wildlife: a review. Hum. Ecol. Risk Assess. 14, 544-567. doi: $10.1080 / 10807030802074220$

Bellinger, B. J., and Hagerthey, S. E. (2010). Presence and diversity of algal toxins in subtropical peatland periphyton: the Florida Everglades, USA 1. J. Phycol. 46, 674-678. doi: 10.1111/j.1529-8817.2010.00832.x

Bercel, T. L., and Kranz, S. (2019). Insights into carbon acquisition and photosynthesis in Karenia brevis under a range of $\mathrm{CO}_{2}$ concentrations. Prog. Oceanogr. 172, 65-76. doi: 10.1016/j.pocean.2019.01.011

Berdalet, E., Fleming, L. E., Gowen, R., Davidson, K., Hess, P., Backer, et al. (2016). Marine harmful algal blooms, human health and wellbeing: challenges and opportunities in the 21st century. J. Mar. Biol. Assoc. U.K. 96, 61-91. doi: 10.1017/S0025315415001733

Bergman, B., Sandh, G., Lin, S., Larsson, J., and Carpenter, E. J. (2013). Trichodesmium-a widespread marine cyanobacterium with unusual nitrogen fixation properties. FEMS Microbiol. Rev. 37, 286-302. doi: 10.1111/j.15746976.2012.00352.x

Bergmann, J. S., and Alam, M. (1981). On the toxicity of the ciguatera producing dinoflagellate, Gambierdiscus toxicus Adachi and Fukuyo isolated from the Florida Keys. J. Environ. Sci. Health Part A 16, 493-500. doi: 10.1080/ 10934528109375000

Berry, J. P., Gantar, M., Gawley, R. E., Wang, M., and Rein, K. S. (2004). Pharmacology and toxicology of pahayokolide A, a bioactive metabolite from a freshwater species of Lyngbya isolated from the Florida Everglades. Comp. Biochem. Physiol. Part C Toxicol. Pharmacol. 139, 231-238. doi: 10.1016/j.cca. 2004.11.005

Berthold, D. E., Lefler, F. W., Laughinghouse, and Iv, H. D. (2020). Untangling filamentous marine cyanobacterial diversity from the coast of South Florida with the description of Vermifilaceae fam. nov. and three new genera: Leptochromothrix gen. nov., Ophiophycus gen. nov., and Vermifilum gen. nov. Mol. Phylogenet. Evol. doi: 10.1016/j.ympev.2020.107010 [Epub ahead of print].

Besada, E. G., and Loeblich, L. A. (1982). Observations on tropical, benthic dinoflagellates from ciguatera-endemic areas: Coolia, Gambierdiscus, and Ostreopsis. Bull. Mar. Sci. 32, 723-735.

Board, O. S., and National Research Council (2000). Clean Coastal Waters: Understanding and Reducing the Effects of Nutrient Pollution. Washington, DC: National Academies Press.

Boesch, D. F., Anderson, D. M., Horner, R. A., Shumway, S. E., Tester, P. A., and Whitledge, T. E. (1996). Harmful Algal Blooms in Coastal Waters: Options for Prevention, Control and Mitigation. NOAA Coastal Ocean Program, Decision Analysis Series No. 10, NOAA Coastal Ocean Office. (Silver Spring, MD: NOAA). 
Bomber, J. W. (1987). Ecology, Genetic Variability and Physiology of the CiguateraCausing Dinoflagellate Gambierdiscus toxicus Adachi \& Fukuyo. Ph.D. thesis. Melbourne, FL: Florida Institute of Technology.

Bomber, J. W., Guillard, R. R., and Nelson, W. G. (1988a). Roles of temperature, salinity, and light in seasonality, growth, and toxicity of ciguatera-causing Gambierdiscus toxicus Adachi et Fukuyo (Dinophyceae). J. Exp. Mar. Biol. Ecol. 115, 53-65. doi: 10.1016/0022-0981(88)90189-X

Bomber, J. W., Morton, S. L., Babinchak, J. A., Norris, D. R., and Morton, J. G. (1988b). Epiphytic dinoflagellates of drift algae-another toxigenic community in the ciguatera food chain. Bull. Mar. Sci. 43, 204-214.

Bomber, J. W., Norris, D. R., and Mitchell, L. E. (1985). "Benthic dinoflagellates associated with ciguatera from the Florida Keys, II. Temporal, spatial, and substrate heterogeneity of Prorocentrum lima," in Toxic Dinoflagellates, eds D. M. Anderson, A. W. White and D. G. Baden (Amsterdam: Elsevier Scientific), 45-50.

Boyer, J. N., Fourqurean, J. W., and Jones, R. D. (1999). Seasonal and long-term trends in the water quality of Florida Bay (1989-1997). Estuaries 22, 417-430. doi: $10.2307 / 1353208$

Bradley, W. G., and Mash, D. C. (2009). Beyond Guam: the cyanobacteria/BMAA hypothesis of the cause of ALS and other neurodegenerative diseases. Amyotroph. Lateral Scler. 10, 7-20. doi: 10.3109/17482960903286009

Brand, L. E., and Compton, A. (2007). Long-term increase in Karenia brevis abundance along the Southwest Florida Coast. Harmful Algae 6, 232-252. doi: 10.1016/j.hal.2006.08.005

Brand, L. E., Pablo, J., Compton, A., Hammerschlag, N., and Mash, D. C. (2010). Cyanobacterial blooms and the occurrence of the neurotoxin, beta-Nmethylamino-l-alanine (BMAA), in South Florida aquatic food webs. Harmful Algae 9, 620-635. doi: 10.1016/j.hal.2010.05.002

Brenner, M., Binford, M. W., and Deevey, E. S. (1990). “Lakes," in Ecosystems of Florida, eds R. L. Myers and J. J. Ewel (Orlando, FL: University of Central Florida Press), 364-391.

Bresnan, E., Davidson, K., Edwards, M., Fernand, L., Gowen, R., Hall, A., et al. (2013). Impacts of climate change on harmful algal blooms. MCCIP Sci. Rev. 2013, 236-243.

Brezonik, P. L., Morgan, W. H., Shannon, E. E., and Putnam, H. D. (1969). Eutrophication factors in north central Florida lakes. Fla. Univ. Eng. Ind. Exp. Stn. Bull. Ser. 23, 1-101.

Bricker, S., Longstaff, B., Dennison, W., Jones, A., Boicourt, K., Wicks, C., et al. (2007). Effects of Nutrient Enrichment In the NationŠs Estuaries: A Decade of Change. NOAA Coastal Ocean Program Decision Analysis Series No. 26. Silver Spring, MD: National Centers for Coastal Ocean Science, 328. Available online at: https://repository.library.noaa.gov/view/noaa/17779

Brinkhuis, V. I., Lueg, J. R., Floyd, L., and Gilliam, D. S. (2008). "Effects of Benthic Cyanobacteria on SE Florida Coral Reef Gorgonian Populations," in Proceedings of the 11th International Coral Reef Symposium, Fort Lauderdale, FL.

Bronk, D., Killberg-Thoreson, L., Sipler, R., Mulholland, M., Roberts, Q., Bernhardt, P., et al. (2014). Nitrogen uptake and regeneration (ammonium regeneration, nitrification and photoproduction) in waters of the West Florida Shelf prone to blooms of Karenia brevis. Harmful Algae 38, 50-62. doi: 10.1016/ j.hal.2014.04.007

Brosnahan, M. L., Fischer, A. D., Lopez, C. B., Moore, S. K., and Anderson, D. M. (2020). Cyst-forming dinoflagellates in a warming climate. Harmful Algae 91, 101728. doi: 10.1016/j.hal.2019.101728

Brown, A. R., Lilley, M., Shutler, J., Lowe, C., Artioli, Y., Torres, R., et al. (2020). Assessing risks and mitigating impacts of harmful algal blooms on mariculture and marine fisheries. Rev. Aquac. 12, 1663-1688. doi: 10.1111/raq. 12403

Bruslé, J. (1997). "Ciguatera fish Poisoning: A Review." Sanitary and Economic Aspects. Paris: Les Editions INSERM, 147.

Bujak, J., Downie, C., Eaton, G., and Williams, G. (1980). "Taxonomy of some Eocene dinoflagellate cyst species from southern England," in Dinoflagellate cysts and acritarchs from the Eocene of southern England, The Palaeontological Association, Special Papers in Palaeontology, Vol. 24, eds J. P. Bujak, C. Downie, G. L. Eaton, and G. L. Williams. (London: Palaeontological Association), 1-100.

Burkholder, J. M. (1998). Implications of harmful microalgae and heterotrophic dinoflagellates in management of sustainable marine fisheries. Ecol. Appl. 8, S37-S62.
Burns, J. (2008). "Toxic cyanobacteria in Florida waters," in Cyanobacterial Harmful Algal Blooms: State of the Science and Research Needs, ed. H. K. Hudnell (New York, NY: Springer), 127-137. doi: 10.1007/978-0-387-75865-7_5

Burns, J. M., and Ferry, J. L. (2007). Adsorption of domoic acid to marine sediments and clays. J. Environ. Monit. 9, 1373-1377. doi: 10.1039/b713101a

Buskey, E. J., and Hyatt, C. J. (1995). Effects of the Texas (USA) Brown tide alga on planktonic grazers. Mar. Ecol. Prog. Ser. 126, 285-292. doi: 10.3354/ meps 126285

Buskey, E. J., Liu, H., Collumb, C., and Bersano, J. G. F. (2001). The decline and recovery of a persistent Texas brown tide algal bloom in the Laguna Madre (Texas, USA). Estuaries 24, 337-346. doi: 10.2307/1353236

Buskey, E. J., Wysor, B., and Hyatt, C. (1998). The role of hypersalinity in the persistence of the Texas 'brown tide' in the Laguna Madre. J. Plankton Res. 20, 1553-1565. doi: 10.1093/plankt/20.8.1553

Cahyanto, I., and Liu-Lastres, B. (2020). Risk perception, media exposure, and visitor's behavior responses to Florida Red Tide. J. Travel Tour. Mark. 37, 447-459. doi: 10.1080/10548408.2020.1783426

Capone, D. G., Ferrier, M. D., and Carpenter, E. J. (1994). Amino acid cycling in colonies of the planktonic marine cyanobacterium Trichodesmium thiebautii. Appl. Environ. Microbiol. 60, 3989-3995. doi: 10.1128/aem.60.11.3989-3995. 1994

Capone, D. G., Zehr, J. P., Paerl, H. W., Bergman, B., and Carpenter, E. J. (1997). Trichodesmium, a globally significant marine cyanobacterium. Science 276, 1221-1229. doi: 10.1126/science.276.5316.1221

Capper, A., and Paul, V. J. (2008). Grazer interactions with four species of Lyngbya in southeast Florida. Harmful Algae 7, 717-728. doi: 10.1016/j.hal.2008.02.004

Capper, A., Flewelling, L. J., and Arthur, K. (2013). Dietary exposure to harmful algal bloom (HAB) toxins in the endangered manatee (Trichechus manatus latirostris) and green sea turtle (Chelonia mydas) in Florida, USA. Harmful Algae 28, 1-9. doi: 10.1016/j.hal.2013.04.009

Carey, C. C., Ibelings, B. W., Hoffmann, E. P., Hamilton, D. P., and Brookes, J. D. (2012). Eco-physiological adaptations that favour freshwater cyanobacteria in a changing climate. Water Res. 46, 1394-1407. doi: 10.1016/j.watres.2011. 12.016

Carlson, D. F., and Clarke, A. J. (2009). Seasonal along-isobath geostrophic flows on the west Florida shelf with application to Karenia brevis red tide blooms in Florida's Big Bend. Cont. Shelf Res. 29, 445-455. doi: 10.1016/j.csr.2008.11.003

Carmichael, W. W. (1992). A status report of planktonic cyanobacteria (blue-green algae) and their toxins. U. S. Environ. Prot. Agency 600, 32-33.

Carmichael, W. W. (2001). Health effects of toxin-producing cyanobacteria:"The CyanoHABs". Hum. Ecol. Risk Assess. 7, 1393-1407. doi: 10.1080/ 20018091095087

Carmichael, W. W., Evans, W. R., Yin, Q. Q., Bell, P., and Moczydlowski, E. (1997). Evidence for paralytic shellfish poisons in the freshwater cyanobacterium Lyngbya wollei (Farlow ex Gomont) comb. nov. Appl. Environ. Microbiol. 63, 3104-3110. doi: 10.1128/aem.63.8.3104-3110.1997

Carpenter, E. J., and Capone, D. G. (eds) (1992). "Nitrogen fixation in Trichodesmium blooms," in Marine Pelagic Cyanobacteria: Trichodesmium and other Diazotrophs, (Berlin: Springer), 211-217. doi: 10.1007/978-94-015-79773_13

Castenholz, R. W., Wilmotte, A., Herdman, M., Rippka, R., Waterbury, J. B., Iteman, I., et al. (2001). "Phylum BX. Cyanobacteria," in Bergey's Manual\$of Systematic Bacteriology. eds D. R. Boone, R. W. Castenholz, G. M. Garrity (New York, NY: Springer), 473-599. doi: 10.1007/978-0-387-21609-6_27

Cato, J. C. (1998). Seafood Safety: Economics of Hazard Analysis and Critical Control Point (HACCP) Programmes (No. 381). Rome: FAO.

CENR (2000). National Assessment of Harmful Algal Blooms in US Waters. Washington, DC: National Science and Technology Council.

Chand, P. (2009). "Seafood neurotoxins I: shellfish poisoning and the nervous system," in Clinical Neurotoxicology, ed. M. R. Dobbs (Amsterdam: Elsevier), 441-447. doi: 10.1016/b978-032305260-3.50046-0

Chateau-Degat, M. L., Chinain, M., Cerf, N., Gingras, S., Hubert, B., and Dewailly, É. (2005). Seawater temperature, Gambierdiscus spp. variability and incidence of ciguatera poisoning in French Polynesia. Harmful Algae 4, 1053-1062. doi: 10.1016/j.hal.2005.03.003

Chateau-Degat, M. L., Dewailly, E., Cerf, N., Nguyen, N. L., Huin-Blondey, M. O., Hubert, B., et al. (2007). Temporal trends and epidemiological aspects of 
ciguatera in French Polynesia: a 10-year analysis. Trop. Med. Int. Health 12, 485-492. doi: 10.1111/j.1365-3156.2006.01798.x

Chen, Q., Wang, M., Zhang, J., Shi, W., Mynett, A. E., Yan, H., et al. (2019). Physiological effects of nitrate, ammonium, and urea on the growth and microcystins contamination of Microcystis aeruginosa: implication for nitrogen mitigation. Water Res. 163:114890. doi: 10.1016/j.watres.2019.114890

Cheng, Y. S., Yue, Z., Irvin, C. M., Kirkpatrick, B., and Backer, L. C. (2007). Characterization of aerosols containing microcystin. Mar. Drugs 5, 136-150. doi: $10.3390 / \mathrm{md} 504136$

Chernoff, N., Hill, D. J., Diggs, D. L., Faison, B. D., Francis, B. M., Lang, J. R., et al. (2017). A critical review of the postulated role of the non-essential amino acid, $\beta$-N-methylamino-L-alanine, in neurodegenerative disease in humans. J. Toxicol. Environ Health Part B 20, 183-229. doi: 10.1080/10937404.2017. 1297592

Cheung, M. Y., Liang, S., and Lee, J. (2013). Toxin-producing cyanobacteria in freshwater: a review of the problems, impact on drinking water safety, and efforts for protecting public health. J. Microbiol. 51, 1-10. doi: 10.1007/s12275013-2549-3

Cheung, W. W., Lam, V. W., Sarmiento, J. L., Kearney, K., Watson, R., and Pauly, D. (2009). Projecting global marine biodiversity impacts under climate change scenarios. Fish Fish. 10, 235-251. doi: 10.1111/j.1467-2979.2008.00315.x

Chew, F. (1955). On the offshore circulation and a convergence mechanism in the red tide region off the west coast of Florida. Eos Trans. Am. Geophys. Union 36, 963-974. doi: 10.1029/TR036i006p00963

Chinain, M., Darius, H. T., Ung, A., Fouc, M. T., Revel, T., Cruchet, P., et al. (2010). Ciguatera risk management in French Polynesia: the case study of Raivavae Island (Australes Archipelago). Toxicon 56, 674-690. doi: 10.1016/j.toxicon. 2009.05.032

Chinain, M., Gatti, C., Darius, H. T., Quod, J. P., and Tester, P. A. (2020a). Ciguatera poisonings: a global review of occurrences and trends. Harmful Algae 102:101873. doi: 10.1016/j.hal.2020.101873

Chinain, M., Gatti, C. M., Roué, M., and Darius, H. T. (2020b). "Ciguateracausing dinoflagellates in the genera Gambierdiscus and Fukuyoa: Distribution, ecophysiology and toxicology," in Dinoflagellates: Morphology, Life History and Ecological Significance, ed. S. R. Durvasula (New York, NY: Nova Science Publishers).

Chiu, A. S., Gehringer, M. M., Welch, J. H., and Neilan, B. A. (2011). Does $\alpha$-amino$\beta$-methylaminopropionic acid (BMAA) play a role in neurodegeneration? Int. J. Environ. Res. Public Health 8, 3728-3746. doi: 10.3390/ijerph8093728

Chorus, I., and Welker, M. (2021). Toxic Cyanobacteria in Water: A Guide to Their Public Health Consequences, Monitoring and Management. Boca Raton, FL: CRC Press. doi: 10.1201/9781003081449

Codd, G. A., Morrison, L. F., and Metcalf, J. S. (2005). Cyanobacterial toxins: risk management for health protection. Toxicol. Appl. Pharmacol. 203, 264-272. doi: 10.1016/j.taap.2004.02.016

Codd, G., Bell, S., Kaya, K., Ward, C., Beattie, K., and Metcalf, J. (1999). Cyanobacterial toxins, exposure routes and human health. Eur. J. Phycol. 34, 405-415. doi: 10.1080/09670269910001736462

Codd, G., Ward, C., and Bell, S. (1997). "Cyanobacterial toxins: occurrence, modes of action, health effects and exposure routes," in Applied Toxicology: Approaches Through Basic Science, eds J. P. Seiler and E. Vilanova (Berlin: Springer), 399-410. doi: 10.1007/978-3-642-60682-3_38

Colby, M. (1943). Poisonous marine animals in the Gulf of Mexico. Proc. Trans. Texas Acad. Sci. 26, 62-69.

Colella, M., Ruzicka, R., Kidney, J., Morrison, J., and Brinkhuis, V. (2012). Coldwater event of January 2010 results in catastrophic benthic mortality on patch reefs in the Florida Keys. Coral Reefs 31, 621-632. doi: 10.1007/s00338-0120880-5

Conger, P. S., Fryxell, G. A., and El-Sayed, S. Z. (1972). "Diatom species reported from the Gulf of Mexico," in Serial Atlas of the Marine Environment, Folio 22: Chemistry, Primary Productivity and Benthic Algae of the Gulf of Mexico, ed. V. C. Bushnell (New York, NY: American Geographical Society), 18-23.

Contento, A., Xu, H., and Gardoni, P. (2018). "A physics-based transportable probabilistic model for climate change dependent storm surge," in Routledge Handbook of Sustainable and Resilient Infrastructure, ed. P. Gardoni (London: Routledge), 662-682. doi: 10.4324/9781315142074-34

Contento, A., Xu, H., and Gardoni, P. (2019). "Risk analysis for hurricanes accounting for the effects of climate change," in Climate Adaptation Engineering
(Butterworth-Heinemann), eds E. Bastidas-Arteaga and M. Stewart (Oxford: Butterworth-Heinemann), 39-72. doi: 10.1016/B978-0-12-816782-3.00002-4

Cordeiro-Araújo, M. K., Chia, M. A., de Toledo Arruda-Neto, J. D., Tornisielo, V. L., Vilca, F. Z., do Carmo, et al. (2016). Microcystin-LR bioaccumulation and depuration kinetics in lettuce and arugula: human health risk assessment. Sci. Total Environ. 566, 1379-1386. doi: 10.1016/j.scitotenv.2016.05.204

Cowell, B. C., and Botts, P. S. (1994). Factors influencing the distribution, abundance and growth of Lyngbya wollei in central Florida. Aquat. Bot. 49, 1-17. doi: 10.1016/0304-3770(94)90002-7

Cox, P. A., Banack, S. A., and Murch, S. J. (2003). Biomagnification of cyanobacterial neurotoxins and neurodegenerative disease among the Chamorro people of Guam. Proc. Natl. Acad. Sci. U.S.A. 100, 13380-13383. doi: $10.1073 /$ pnas.2235808100

Cox, P. A., Banack, S. A., Murch, S. J., Rasmussen, U., Tien, G., Bidigare, R. R., et al. (2005). Diverse taxa of cyanobacteria produce $\beta$-N-methylamino-L-alanine, a neurotoxic amino acid. Proc. Natl. Acad. Sci. U.S.A. 102, 5074-5078. doi: 10.1073/pnas.0501526102

Cross, I. D., Mcgowan, S., Needham, T., and Pointer, C. M. (2014). The effects of hydrological extremes on former gravel pit lake ecology: management implications. Fundam. Appl. Limnol. 185, 71-90. doi: 10.1127/fal/2014/0573

Dai, R., Liu, H., Qu, J., Zhao, X., and Hou, Y. (2009). Effects of amino acids on microcystin production of the Microcystis aeruginosa. J. Hazard. Mater. 161, 730-736. doi: 10.1016/j.jhazmat.2008.04.015

Dale, B., Edwards, M., and Reid, P. C. (2006). "Climate change and harmful algal blooms," in Ecology of Harmful Algae. Ecological Studies (Analysis and Synthesis), Vol. 189, eds E. Granéli and J. T. Turner (Berlin: Springer), 367-378. doi: 10.1007/978-3-540-32210-8_28

Davidson, K., Miller, P., Wilding, T. A., Shutler, J., Bresnan, E., Kennington, K., et al. (2009). A large and prolonged bloom of Karenia mikimotoi in Scottish waters in 2006. Harmful Algae 8, 349-361. doi: 10.1016/j.hal.2008. 07.007

Davis, C. C. (1948). Gymnodinium brevis sp. nov., a cause of discolored water and animal mortality in the Gulf of Mexico. Bot. Gaz. 109, 358-360. doi: $10.1086 / 335488$

Davis, D. A., Mondo, K., Stern, E., Annor, A. K., Murch, S. J., Coyne, T. M., et al. (2019). Cyanobacterial neurotoxin BMAA and brain pathology in stranded dolphins. PLoS One 14:e0213346. doi: 10.1371/journal.pone.0213346

Davis, T. W., Berry, D. L., Boyer, G. L., and Gobler, C. J. (2009). The effects of temperature and nutrients on the growth and dynamics of toxic and non-toxic strains of Microcystis during cyanobacteria blooms. Harmful Algae 8, 715-725. doi: 10.1016/j.hal.2009.02.004

Dawson, E. Y., Aleem, A. A., and Halstead, B. W. (1955). Marine algae from Palmyra Island with special reference to the feeding habits and toxicology of reef fishes. Occ. Pap. Allan Hancock Fdn. 17, 1-39.

de Figueiredo, D. R., Reboleira, A. S., Antunes, S. C., Abrantes, N., Azeiteiro, U., Goncalves, F., et al. (2006). The effect of environmental parameters and cyanobacterial blooms on phytoplankton dynamics of a Portuguese temperate lake. Hydrobiologia 568, 145-157. doi: 10.1007/s10750-006-0196-y

de Haro, L., Pommier, P., and Valli, M. (2003). Emergence of imported ciguatera in Europe: report of 18 cases at the Poison Control Centre of Marseille. J. Toxicol. Clin. Toxicol. 7, 927-930. doi: 10.1081/clt-120026512

de Sylva, D. P. (1956). Poisoning by Barracuda and Other Fishes. Fairbanks, AK: Marine Laboratory, University of Miami.

de Sylva, D. P. (1982). A Comparative Survey of the Populations of a Dinoflagellate, Gambierdiscus toxicus, in the Vicinity of St. Thomas, U.S. Virgin Islands. NOAA Contract NA80-RAA-04083. (Coral Gables, FL: University of Miami), 78.

de Sylva, D. P. (1994). Distribution and ecology of ciguatera fish poisoning in Florida, with emphasis on the Florida Keys. Bull. Mar. Sci. 54, 944-954.

Deichmann, W. B., MacDonald, W. E., Cubit, D. A., Wunsch, C. E., Bartels, J. E., and Merritt, F. R. (1977). Pain in jawbones and teeth in ciguatera intoxications. Fla. Sci. 227-237.

Del Rio, R., Bargu, S., Baltz, D., Fire, S., Peterson, G., and Wang, Z. (2010). Gulf menhaden (Brevoortia patronus): a potential vector of domoic acid in coastal Louisiana food webs. Harmful Algae 10, 19-29. doi: 10.1016/j.hal.2010. 05.006

Dennison, W. C., O'neil, J. M., and Duffy, E. J. (1999). Bloom of the cyanobacterium Lyngbya majuscula in coastal waters of Queensland, Australia. Bull. Inst. Oceanogr. 19, 501-506. 
Detoni, A. M. S., Costa, L. D. F., Pacheco, L. A., and Yunes, J. S. (2016). Toxic Trichodesmium bloom occurence in the southwestern South Atlantic Ocean. Toxicon 110, 51-55. doi: 10.1016/j.toxicon.2015.12.003

DeYoe, H. R., Stockwell, D. A., Blolagare, R. R., Latasa, M., Johnson, P. W., Hargraves, P. E., et al. (1997). Description and characterization of the algal species Aureoumbra lagunensis gen. et sp. nov. and referral of Aureoumbra and Aureococcus to the Pelagophyceae. J. Phycol. 33, 1042-1048. doi: 10.1111/j. 0022-3646.1997.01042.x

Dickey, R. W., and Plakas, S. M. (2010). Ciguatera: a public health perspective. Toxicon 56, 123-136. doi: 10.1016/j.toxicon.2009.09.008

Dierssen, H., Chlus, A., and Russell, B. (2015). Hyperspectral discrimination of floating mats of seagrass wrack and the macroalgae Sargassum in coastal waters of Greater Florida Bay using airborne remote sensing. Remote Sens. Environ. 167, 247-258. doi: 10.1016/j.rse.2015.01.027

Díez-Quijada, L., Puerto, M., Gutiérrez-Praena, D., Llana-Ruiz-Cabello, M., Jos, A., and Cameán, A. M. (2019). Microcystin-RR: occurrence, content in water and food and toxicological studies. A review. Environ. Res. 168, 467-489. doi: 10.1016/j.envres.2018.07.019

DiLeone, A. G., and Ainsworth, C. (2019). Effects of Karenia brevis harmful algal blooms on fish community structure on the West Florida Shelf. Ecol. Model. 392, 250-267. doi: 10.1016/j.ecolmodel.2018.11.022

Dixon, L. K., Kirkpatrick, G. J., Hall, E. R., and Nissanka, A. (2014a). Nitrogen, phosphorus and silica on the West Florida Shelf: patterns and relationships with Karenia spp. occurrence. Harmful Algae 38, 8-19. doi: 10.1016/j.hal.2014.07. 001

Dixon, L. K., Murphy, P. J., Becker, N. M., and Charniga, C. M. (2014b). The potential role of benthic nutrient flux in support of Karenia blooms in west Florida (USA) estuaries and the nearshore Gulf of Mexico. Harmful Algae 38, 30-39. doi: 10.1016/j.hal.2014.04.005

do Carmo Bittencourt-Oliveira, M., Cordeiro-Araújo, M. K., Chia, M. A., de Toledo Arruda-Neto, J. D., de Oliveira, Ê. T., and dos Santos, F. (2016). Lettuce irrigated with contaminated water: photosynthetic effects, antioxidative response and bioaccumulation of microcystin congeners. Ecotoxicol. Environ. Saf. 128, 83-90. doi: 10.1016/j.ecoenv.2016.02.014

Doblin, M. A., Coyne, K. J., Rinta-Kanto, J. M., Wilhelm, S. W., and Dobbs, F. C. (2007). Dynamics and short-term survival of toxic cyanobacteria species in ballast water from NOBOB vessels transiting the Great Lakes-implications for HAB invasions. Harmful Algae 6, 519-530. doi: 10.1016/j.hal.2006.05.007

Glibert, P. M. (2020). From hogs to HABs: impacts of industrial farming in the US on nitrogen and phosphorus and greenhouse gas pollution. Biogeochemistry. doi: 10.1007/s10533-020-00691-6

Dow, C. S., and Swoboda, U. K. (2000). "Cyanotoxins," in The Ecology of Cyanobacteria, eds B. A. Whitton and M. Potts (Dordrecht: Springer), 613-632. doi: 10.1007/0-306-46855-7_22

Dubose, C., Langeland, K., and Phlips, E. J. (1997). Problem freshwater algae and their control in Florida. Aquatics 19, 4-13.

Dupont, J. M., Hallock, P., and Jaap, W. C. (2010). Ecological impacts of the 2005 red tide on artificial reef epibenthic macroinvertebrate and fish communities in the eastern Gulf of Mexico. Mar. Ecol. Prog. Ser. 415, 189-200. doi: 10.3354/ meps08739

Durako, M. J., Hall, M. O., and Merello, M. (2002). "Patterns of change in the seagrass dominated Florida Bay hydroscape," in The Everglades, Florida Bay and coral reefs of the Florida Keys, An Ecosystem Sourcebook, eds J. W. Porter and K. G. Porter (Boca Raton, FL: CRC Press), 523-537.

Edwards, M., Johns, D. G., Leterme, S. C., Svendsen, E., and Richardson, A. J. (2006). Regional climate change and harmful algal blooms in the northeast Atlantic. Limnol. Oceanogr. 51, 820-829. doi: 10.4319/lo.2006.51.2. 0820

Emanuel, K. A. (2013). Downscaling CMIP5 climate models shows increased tropical cyclone activity over the 21 st century. Proc. Natl. Acad. Sci. U.S.A. 110, 12219-12224. doi: 10.1073/pnas.1301293110

Engene, N., Paul, V. J., Byrum, T., Gerwick, W. H., Thor, A., and Ellisman, M. H. (2013). Five chemically rich species of tropical marine cyanobacteria of the genus Okeania gen. nov. (Oscillatoriales, Cyanoprokaryota). J. Phycol. 49, 1095-1106. doi: 10.1111/jpy.12115

Engene, N., Rottacker, E. C., Kaštovsk $\iota$, J., Byrum, T., Choi, H., Ellisman, M. H., et al. (2012). Moorena producens gen. nov., sp. nov. and Moorena bouillonii comb. nov., tropical marine cyanobacteria rich in bioactive secondary metabolites. Int. J. Syst. Evol. Microbiol. 62(Pt 5), 1171. doi: 10.1099/ijs.0. 033761-0

Engene, N., Tronholm, A., and Paul, V. J. (2018). Uncovering cryptic diversity of Lyngbya: the new tropical marine cyanobacterial genus Dapis (Oscillatoriales). J. Phycol. 54, 435-446. doi: 10.1111/jpy.12752

Errera, R. M., Yvon-Lewis, S., Kessler, J. D., and Campbell, L. (2014). Reponses of the dinoflagellate Karenia brevis to climate change: $\mathrm{pCO}_{2}$ and sea surface temperatures. Harmful Algae 37, 110-116. doi: 10.1016/j.hal.2014.05.012

Evans, G., and Jones, L. (2001). Economic Impact of the 2000 Red Tide on Galveston County, Texas: A Case Study. College Station: Texas A\&M University.

Evens, T. J., and Leblond, J. D. (2004). "Photophysiology of the Florida red tide Karenia brevis: modifications in the thylakoid lipid composition in response to environmental conditions," in Harmful Algae 2002, Proceedings of the Xth International Conference on Harmful Algae, Florida Fish and Wildlife Commission, eds K. A. Steidinger, J. H. Landsberg, C. R. Tomas, and G. A. Vargo (St. Petersburg, FL: Florida Institute of Oceanography), 414-416.

Evens, T. J., Kirkpatrick, G. J., Millie, D. E., Chapman, D. J., and Schofield, O. M. E. (2001). Photophysiological responses of the toxic red-tide dinoflagellate Gymnodinium breve (Dinophyceae) under natural sunlight. J. Plankton Res. 23, 1177-1194. doi: 10.1093/plankt/23.11.1177

Faassen, E. J. (2014). Presence of the neurotoxin BMAA in aquatic ecosystems: What do we really know? Toxins 6, 1109-1138. doi: 10.3390/toxins6031109

Falconer, I. R. (1999). An overview of problems caused by toxic blue-green algae (cyanobacteria) in drinking and recreational water. Environ. Toxicol. Int. J. 14, 5-12. doi: 10.1002/(sici)1522-7278(199902)14:1<5::aid-tox3>3.0.co;2-0

Falconer, I. R., and Humpage, A. R. (2005). Health risk assessment of cyanobacterial (blue-green algal) toxins in drinking water. Int. J. Environ. Res. Public Health 2, 43-50. doi: 10.3390/ijerph2005010043

Falk, M., Seto, P. F., and Walter, J. A. (1991). Solubility of domoic acid in water and in non-aqueous solvents. Can. J. Chem. 69, 1740-1744. doi: 10.1139/v91-255

Falkowski, P. (2012). Ocean science: the power of plankton. Nature 483, S17-S20. doi: $10.1038 / 483 \mathrm{~s} 17 \mathrm{a}$

Fauquier, D. A., Flewelling, L. J., Maucher, J., Manire, C. A., Socha, V., Kinsel, M. J., et al. (2013). Brevetoxin in blood, biological fluids, and tissues of sea turtles naturally exposed to Karenia brevis blooms in central west Florida. J. Zoo Wildl. Med. 44, 364-375. doi: 10.1638/2012-0164r.1

Field, C. B., Behrenfeld, M. J., Randerson, J. T., and Falkowski, P. (1998). Primary production of the biosphere: integrating terrestrial and oceanic components. Science 281, 237-240. doi: 10.1126/science.281.5374.237

Filippelli, G. M. (2011). Phosphate rock formation and marine phosphorus geochemistry: the deep time perspective. Chemosphere 84, 759-766. doi: 10 . 1016/j.chemosphere.2011.02.019

Fiore, M. F., De Lima, S. T., Carmichael, W. W., Mckinnie, S. M. K., Chekan, J. R., and Moore, B. S. (2020). Guanitoxin, re-naming a cyanobacterial organophosphate toxin. Harmful Algae 92:101737. doi: 10.1016/j.hal.2019. 101737

Fire, S. E., Fauquier, D., Flewelling, L. J., Henry, M., Naar, J., Pierce, R., et al. (2007). Brevetoxin exposure in bottlenose dolphins (Tursiops truncatus) associated with Karenia brevis blooms in Sarasota Bay, Florida. Mar. Biol. 152, 827-834. doi: 10.1007/s00227-007-0733-x

Fire, S. E., Flewelling, L. J., Stolen, M., Durden, W. N., de Wit, M., Spellman, A. C., et al. (2015). Brevetoxin-associated mass mortality event of bottlenose dolphins and manatees along the east coast of Florida, USA. Mar. Ecol. Prog. Ser. 526, 241-251. doi: 10.3354/meps11225

Flaherty, K. E., and Landsberg, J. H. (2011). Effects of a persistent red tide (Karenia brevis) bloom on community structure and species-specific relative abundance of nekton in a Gulf of Mexico estuary. Estuaries Coasts 34, 417-439. doi: 10. 1007/S12237-010-9350-X

Fleming, L. E., Backer, L. C., and Baden, D. G. (2005). Overview of aerosolized Florida red tide toxins: exposures and effects. Environ. Health Perspect. 113, 618-620. doi: 10.1289/ehp.7501

Fleming, L. E., Baden, D. G., Bean, J. A., Weisman, R., and Blythe, D. G. (1998). "Marine seafood toxin diseases: issues in epidemiology \& community outreach," in Environmental Health. Xunta de Galicia and Intergovernmental Oceanographic Commission of UNESCO B Reguera, eds J. Blanco, M. L. Fernandez, and T. Wyatt (Lugo: UNESCO), 245-248.

Fleming, L. E., Blythe, D. G., and Baden, D. G. (1997). Ciguatera fish poisoning. Shoreman's Travel Med. Mon. 1, 1-5. 
Fleming, L. E., Kirkpatrick, B., Backer, L. C., Bean, J. A., Wanner, A., Reich, A., et al. (2007). Aerosolized red-tide toxins (brevetoxins) and asthma. Chest 131, 187-194. doi: 10.1378/chest.06-1830

Fleming, L. E., Kirkpatrick, B., Backer, L. C., Walsh, C. J., Nierenberg, K., Clark, J., et al. (2011). Review of Florida red tide and human health effects. Harmful Algae 10, 224-233. doi: 10.1016/j.hal.2010.08.006

Fleming, L. E., Rivero, C., Burns, J., Williams, C., Bean, J. A., Shea, K. A., et al. (2002). Blue green algal (cyanobacterial) toxins, surface drinking water, and liver cancer in Florida. Harmful Algae 1, 157-168. doi: 10.1016/S1568-9883(02) 00026-4

Flewelling, L. J., Manire, C. A., Stacy, B., Foley, A., Rodriguez, M., Perry, S., et al. (2015). "Domoic acid in stranded juvenile green sea turtles, Chelonia mydas, in Southeast Florida," in Proceedings of the Eighth Symposium on Harmful Algae in the U.S, Long Beach, CA, 63.

Flewelling, L. J., Naar, J. P., Abbott, J. P., Baden, D. G., Barros, N. B., Bossart, G. D., et al. (2005). Red tides and marine mammal mortalities. Nature 435, 755-756. doi: 10.1038/nature435755a

Foley, A. M., Stacy, B. A., Schueller, P., Flewelling, L. J., Schroeder, B., Minch, K., et al. (2019). Assessing Karenia brevis red tide as a mortality factor of sea turtles in Florida, USA. Dis. Aquat. Organ. 132, 109-124. doi: 10.3354/dao03308

Foss, A. J., Phlips, E. J., Yilmaz, M., and Chapman, A. (2012). Characterization of paralytic shellfish toxins from Lyngbya wollei dominated mats collected from two Florida springs. Harmful Algae 16, 98-107. doi: 10.1016/j.hal.2012.02.004

Franks, J., Johnson, D., Ko, D.-S., Sanchez-Rubio, G., Hendon, R., and Lay, M. (2011). Unprecedented Influx of Pelagic Sargassum Along Caribbean Island Coastlines During 2011. Gulf Caribb. Fish. Inst. 64, 6-8.

Friedman, M. A., Fernandez, M., Backer, L. C., Dickey, R. W., Bernstein, J., Schrank, K., et al. (2017). An updated review of ciguatera fish poisoning: clinical, epidemiological, environmental, and public health management. Mar. Drugs 15:72. doi: 10.3390/md15030072

Friedman, M. A., Fleming, L. E., Fernandez, M., Bienfang, P., Schrank, K., Dickey, R., et al. (2008). Ciguatera fish poisoning: treatment, prevention and management. Mar. Drugs 6, 456-479.

Fristachi, A., and Sinclair, J. L. (2008). "Occurrence of cyanobacterial harmful algal blooms workgroup report," in Cyanobacterial Harmful Algal Blooms: State of the Science and Research Needs, ed. K. H. Hudnell (New York, NY: Springer), 45-103. doi: 10.1007/978-0-387-75865-7_3

Fryxell, G. A., and Hasle, G. R. (2003). “Taxonomy on harmful algae," in Manual on Harmful Marine Microalgae, eds G. M. Hallegraeff, D. M. Anderson, and A. D. Cembella (Paris: UNESCO), 465-509.

Fryxell, G. A., and Villac, M. C. (1999). "Toxic and harmful marine diatoms," in The Diatoms: Applications for the Environmental and Earth Sciences, eds E. F. Stoermer and J. P. Smol (Cambridge: Cambridge University Press), 419-428. doi: $10.1017 /$ cbo9780511613005.022

Gallegos-Martínez, M., Meave, del Castillo, M. E., Álvarez, C. S., Sentíes-Granados, A., Roldán, R. R., et al. (2009). "Biodiversidad Costera en la Sonda de Campeche," in PEMEX y la Salud Ambiental en la Sonda de Campeche.", eds A. L. Soto and Y. M. C. González-Macías (México: IMP-Battelle Memorial Institute- NAMUAM), 169-264.

Galtsoff, P. S. (1948). Red tide. Progress report on the cause of the mortality of fish along the west coast of Florida conducted by the U.S. Fish and Wildlife Service and cooperating organizations. U.S. Fish Wildl. Serv. Spec. Sci. Rev. 46:44.

Gambaro, A., Barbaro, E., Zangrando, R., and Barbante, C. (2012). Simultaneous quantification of microcystins and nodularin in aerosol samples using highperformance liquid chromatography/negative electrospray ionization tandem mass spectrometry. Rapid Commun. Mass Spectrom. 26, 1497-1506. doi: 10. 1002/rcm.6246

Gannon, D. P., McCabe, E. J. B., Camilleri, S. A., Gannon, J. G., Brueggen, M. K., Barleycorn, A. A., et al. (2009). Effects of Karenia brevis harmful algal blooms on nearshore fish communities in southwest Florida. Mar. Ecol. Prog. Ser. 378, 171-186. doi: 10.3354/meps07853

Garate-Lizarraga, I., and Gonzalez-Armas, R. (2011). Occurrence of Pyrodinium bahamense var. compressum along the southern coast of the Baja California Peninsula. Mar. Pollut. Bull. 62, 626-630. doi: 10.1016/j.marpolbul.2011.01.009

Geesey, M., and Tester, P. A. (1993). “Gymnodinium breve: ubiquitous in Gulf of Mexico waters?," in Toxic Phytoplankton Blooms in the Sea, eds T. J. Smayda and Y. Shimizu (New York, NY: Elsevier), 251-255.
Gervais, A. J., and Maclean, J. G. (1985). "Management of fisheries and public health problems associated with toxic dinoflagellates," in Toxic Dinoflagellates, Proceedings of the Third International Conferences, eds D. M. Anderson, A. W. White, and D. G. Baden (New York, NY: Elsevier), 530-533.

Gingold, D. B., Strickland, M. J., and Hess, J. J. (2014). Ciguatera fish poisoning and climate change: analysis of National Poison Center data in the United States, 2001-2011. Environ. Health Perspect. 122, 580-586. doi: 10.1289/ehp.1307196

Glibert, P. M., and Bronk, D. A. (1994). Release of dissolved organic nitrogen by marine diazotrophic cyanobacteria, Trichodesmium spp. Appl. Environ. Microbiol. 60, 3996-4000. doi: 10.1128/aem.60.11.3996-4000.1994

Glibert, P. M., and Burkholder, J. (2006). "The Complex Relationships between Increases in Fertilization of the earth, coastal eutrophication and proliferation of harmful algal blooms," in Ecology of Harmful Algae, eds E. Granéli and J. T. Turner (Berlin: Springer), 341-354. doi: 10.1007/978-3-540-32210-8_26

Glibert, P. M., Boyer, J., Heil, C., Madden, C., Sturgis, B., and Wazniak, C. (2010). "Blooms in Lagoons: different from those of river-dominated estuaries," in Coastal Lagoons: Critical Habitats of Environmental Change, eds M. J. Kennish and H. W. Paerl (Boca Raton, FL: CRC Press), 91-114. doi: 10.1201/ ebk1420088304-c5

Glibert, P. M., Burkholder, J. M., Kana, T. M., Alexander, J., Skelton, H., and Shilling, C. (2009a). Grazing by Karenia brevis on Synechococcus enhances its growth rate and may help to sustain blooms. Aquat. Microb. Ecol. 55, 17-30. doi: 10.3354/ame01279

Glibert, P. M., Harrison, J., Heil, C., and Seitzinger, S. (2006). Escalating worldwide use of urea-a global change contributing to coastal eutrophication. Biogeochemistry 77, 441-463. doi: 10.1007/s10533-005-3070-5

Glibert, P. M., Heil, C. A., and Madden, C. J. (2009b). Florida Bay: a subtropical system increasingly influenced by multiple stressors. Contrib. Mar. Sci. 38, 1-4.

Glibert, P. M., Heil, C. A., Hollander, D., Revilla, M., Hoare, A., Alexander, J., et al. (2004). Evidence for dissolved organic nitrogen and phosphorus uptake during a cyanobacterial bloom in Florida Bay. Mar. Ecol. Prog. Ser. 280, 73-83. doi: $10.3354 /$ meps 280073

Glibert, P. M., Heil, C. A., Madden, C. J., and Kelly, S. P. (2021). Dissolved organic nutrients at the interface of fresh and marine waters: flow regime changes, biogeochemical cascades and picocyanobacterial blooms-the Example of Florida Bay, USA. Biogeochemistry. doi: 10.1007/s10533-021-00760-4.

Glibert, P. M., Heil, C. A., Rudnick, D. T., Madden, C. J., Boyer, J. N., and Kelly, S. (2009c). Florida Bay: water quality status and trends, historic and emerging algal bloom problems. Contrib. Mar. Sci. 38, 5-17.

Glibert, P. M., Icarus Allen, J., Artioli, Y., Beusen, A., Bouwman, L., Harle, J., et al. (2014). Vulnerability of coastal ecosystems to changes in harmful algal bloom distribution in response to climate change: projections based on model analysis. Glob. Change Biol. 20, 3845-3858. doi: 10.1111/gcb.12662

Glibert, P. M., Landsberg, J. H., Evans, J. J., Al-Sarawi, M. A., Faraj, M., Al-Jarallah, M. A., et al. (2002). A fish kill of massive proportion in Kuwait Bay, Arabian Gulf, 2001: the roles of bacterial disease, harmful algae, and eutrophication. Harmful Algae 1, 215-231. doi: 10.1016/S1568-9883(02)00013-6

Glibert, P. M., Seitzinger, S., Heil, C. A., Burkholder, J. M., Parrow, M. W., Codispoti, L. A., et al. (2005). Eutrophication. Oceanography 18:198.

Gobler, C. J. (2020). Climate change and harmful algal blooms: insights and perspective. Harmful Algae 91:101731. doi: 10.1016/j.hal.2019.101731

Gobler, C. J., and Sunda, W. G. (2012). Ecosystem disruptive algal blooms of the brown tide species, Aureococcus anophagefferens and Aureoumbra lagunensis. Harmful Algae 14, 36-45. doi: 10.1016/j.hal.2011.10.013

Gobler, C. J., Koch, F., Kang, Y., Berry, D. L., Tang, Y. Z., Lasi, M., et al. (2013). Expansion of harmful brown tides caused by the pelagophyte, Aureoumbra lagunensis DeYoe et Stockwell, to the US east coast. Harmful Algae 27, 29-41. doi: 10.1016/j.hal.2013.04.004

Gómez, F., Qiu, D., Lopes, R. M., and Lin, S. (2015). Fukuyoa paulensis gen. et sp. nov., a new genus for the globular species of the dinoflagellate Gambierdiscus (Dinophyceae). PLoS One 10:e0119676. doi: 10.1371/journal.pone. 0119676

Gore, R. H., Gallaher, E. E., Scotto, L. E., and Wilson, K. A. (1981). Studies on decapod crustacea from the Indian River Region of Florida: XI. Community composition, structure, biomass and species-areal relationships of seagrass and drift algae-associated macrocrustaceans. Estuar. Coast. Shelf Sci. 12, 485-508. doi: 10.1016/S0302-3524(81)80007-2 
Graham, H. W., Amison, J. M., and Marvin, K. T. (1954). Phosphorus Content of Waters Along the West Coast of Florida. Washington, DC: Fish and Wildlife Service.

Graham, L. E., and Wilcox, L. W. (2000). In Algae. Upper Saddle River, NJ: Prentice Hall, 640.

Griffith, A. W., and Gobler, C. J. (2020). Harmful algal blooms: a climate change co-stressor in marine and freshwater ecosystems. Harmful Algae 91:101590. doi: 10.1016/j.hal.2019.03.008

Groisman, P. Y., Knight, R. W., and Karl, T. R. (2012). Changes in intense precipitation over the central United States. J. Hydrometeorol. 13, 47-66. doi: 10.1175/JHM-D-11-039.1

Gudger, E. W. (1918). Sphyraena Barracuda; Its Morphology, Habits, and History. Papers from the Department of Marine Biology of the Carnegie Institution of Washington, Vol. 12, (Washington, DC: Carnegie Institution of Washington's), 53-105.

Guist, G. G., and Humm, H. J. (1976). Effects of sewage effluents on the growth of Ulva lactuca. Fla. Sci. 39, 267-271.

Habas, E. J., and Gilbert, C. K. (1974). The economic effects of the 1971 Florida red tide and the damage it presages for future occurrences. Environ. Lett. 6, 139-147. doi: 10.1080/00139307409437354

Hales, S., Weinstein, P., and Woodward, A. (1999). Ciguatera (fish poisoning), El Niño, and Pacific sea surface temperatures. Ecosyst. Health 5, 20-25. doi: 10.1046/j.1526-0992.1999.09903.x

Hall, M. O., Durako, M. J., Fourqurean, J. W., and Zieman, J. C. (1999). Decadal changes in seagrass distribution and abundance in Florida Bay. Estuaries 22, 445-459. doi: 10.2307/1353210

Hall, N. S., Litaker, R. W., Kenworthy, W. J., Vandersea, M. W., Sunda, W. G., Reid, J. P., et al. (2018). Consortial brown tide- picocyanobacteria blooms in Guantánamo Bay, Cuba. Harmful Algae 73, 30-43. doi: 10.1016/j.hal.2018.01. 003

Hallegraeff, G. M. (1993). A review of harmful algal blooms and their apparent global rise. Hansen Phycol. 32, 79-99. doi: 10.2216/i0031-8884-32$2-79.1$

Hallegraeff, G. M. (2010). Ocean climate change, phytoplankton community responses, and harmful algal blooms: a formidable predictive challenge 1 . J. Phycol. 46, 220-235. doi: 10.1111/j.1529-8817.2010.00815.x

Hallegraeff, G., and Gollasch, S. (2006). "Anthropogenic Introductions of Microalgae," in Ecology of Harmful Algae. Ecological Studies (Analysis and Synthesis), Vol. 189, eds E. Granéli and J. T. Turner (Berlin: Springer), 379-390.

Hallegraeff, G., Dorantes-Aranda, J. J., Mardones, J., and Seger, A. (2017). "Review of progress in our understanding of fish-killing microalgae: implications for management and mitigation," in Proceedings of the 17th International Conference on Harmful Algae 2016, International Society for the Study of Harmful Algae (ISSHA), Intergovernmental Oceanographic Commission of UNESCO, eds L. A. O. Proenca and G. M. Hallegraeff (Brussels: International Society for the Study of Harmful Algae (ISSHA)).

Hanazaki, N., Herbst, D. F., Marques, M. S., and Vandebroek, I. (2013). Evidence of the shifting baseline syndrome in ethnobotanical research. J. Ethnobiol. Ethnomed. 9:75. doi: 10.1186/1746-4269-9-75

Hardison, D. R., Holland, W. C., Currier, R. D., Kirkpatrick, B., Stumpf, R., Fanara, T., et al. (2019). HABscope: a tool for use by citizen scientists to facilitate early warning of respiratory irritation caused by toxic blooms of Karenia brevis. PLoS One 14:e0218489. doi: 10.1371/journal.pone.0218489

Hardison, D. R., Sunda, W. G., Shea, D., and Litaker, R. W. (2013). Increased toxicity of Karenia brevis during phosphate limited growth: ecological and evolutionary implications. PLoS One 8:e58545. doi: 10.1371/journal.pone. 0058545

Hardison, D. R., Sunda, W. G., Tester, P. A., Shea, D., and Litaker, W. R. (2014). Increased cellular brevetoxins in the red tide dinoflagellate Karenia brevis under $\mathrm{CO}_{2}$ limitation of growth rate: evolutionary implications and potential effects on bloom toxicity. Limnol. Oceanogr. 59, 560-577. doi: 10.4319/lo.2014.59.2. 0560

Hardison, R. D., Sunda, W. G., Litaker, R. W., Shea, D., and Tester, P. A. (2012). Nitrogen limitation inceases brevetoxins in Karenia brevis (Dinophyceae): implications for bloom toxicity. J. Phycol. 48, 844-858. doi: 10.1111/j.15298817.2012.01186.x

Harke, M. J., Steffen, M. M., Gobler, C. J., Otten, T. G., Wilhelm, S. W., Wood, S. A., et al. (2016). A review of the global ecology, genomics, and biogeography of the toxic cyanobacterium, Microcystis spp. Harmful Algae 54, 4-20. doi: 10.1016/j.hal.2015.12.007

Harr, K. E., Szabo, N. J., Cichra, M., and Phlips, E. J. (2008). Debromoaplysiatoxin in Lyngbya-dominated mats on manatees (Trichechus manatus latirostris) in the Florida King's Bay ecosystem. Toxicon 52, 385-388. doi: 10.1016/j.toxicon.2008. 05.016

Havens, K. E., and James, R. T. (2005). The phosphorus mass balance of Lake Okeechobee, Florida: implications for eutrophication management. Lake Reserv. Manage. 21, 139-148. doi: 10.1080/07438140509354423

Havens, K. E., and Paerl, H. W. (2015). Climate change at a crossroad for control of harmful algal blooms. Environ. Sci. Technol. 49, 12605-12606. doi: 10.1021/ acs.est.5b03990

Havens, K. E., and Steinman, A. D. (2015). Ecological responses of a large shallow lake (Okeechobee, Florida) to climate change and potential future hydrologic regimes. Environ. Manage. 55, 763-775. doi: 10.1007/s00267-013-0189-3

Havens, K. E., Fukushima, T., Xie, P., Iwakuma, T., James, R. T., Takamura, N., et al. (2001). Nutrient dynamics and the eutrophication of shallow lakes Kasumigaura (Japan), Donghu (PR China), and Okeechobee (USA). Environ. Pollut. 111, 263-272. doi: 10.1016/S0269-7491(00)00074-9

Havens, K. E., James, R. T., East, T. L., and Smith, V. H. (2003). N: P ratios, light limitation, and cyanobacterial dominance in a subtropical lake impacted by non-point source nutrient pollution. Environ. Pollut. 122, 379-390. doi: 10.1016/s0269-7491(02)00304-4

Havens, K. E., Ji, G., Beaver, J. R., Fulton, R. S., and Teacher, C. E. (2019). Dynamics of cyanobacteria blooms are linked to the hydrology of shallow Florida lakes and provide insight into possible impacts of climate change. Hydrobiologia 829, 43-59. doi: 10.1007/s10750-017-3425-7

Havens, K., East, T., and Beaver, J. (1996). Experimental studies of zooplanktonphytoplankton-nutrient interactions in a large subtropical lake (Lake Okeechobee, Florida, USA). Freshw. Biol. 36, 579-597. doi: 10.1046/j.13652427.1996.00122.x

Haverkamp, D., Steidinger, K. A., and Heil, C. A. (2004). "HAB monitoring and databases: the Florida Karenia brevis example," in Harmful Algae Management and Mitigation, eds S. Hall, S. Etheridge, D. Anderson, J. Kleindinst, M. Zhu, and Y. Zou (Singapore: Asia-Pacific Economic Cooperation), 102-109.

Hawser, S., O’Neil, J., Roman, M., and Codd, G. (1992). Toxicity of blooms of the cyanobacterium Trichodesmium to zooplankton. J. Appl. Phycol. 4, 79-86. doi: 10.1007/bf00003963

He, X., Liu, Y.-L., Conklin, A., Westrick, J., Weavers, L. K., Dionysiou, D. D., et al. (2016). Toxic cyanobacteria and drinking water: impacts, detection, and treatment. Harmful Algae 54, 174-193. doi: 10.1016/j.hal.2016.01.001

Heil, C. A. (1986). Vertical Migration of Ptychodiscus brevis (Davis) Steidinger. Master's thesis. Tampa, FL: University of South Florida.

Heil, C. A., and Steidinger, K. A. (2009). Monitoring, management, and mitigation of Karenia blooms in the eastern Gulf of Mexico. Harmful Algae 8, 611-617. doi: 10.1016/j.hal.2008.11.006

Heil, C. A., Bronk, D. A., Dixon, L. K., Hitchcock, G. L., and Kirkpatrick, G. J. (2014a). The Gulf of Mexico ECOHAB: Karenia Program 2006-2012. Harmful Algae 38, 3-7. doi: 10.1016/j.hal.2014.07.015

Heil, C. A., Bronk, D. A., Mulholland, M. R., O’Neil, J. M., Bernhardt, P. W., Murasko, S., et al. (2014b). Influence of daylight surface aggregation behavior on nutrient cycling during a Karenia brevis (Davis) G. Hansen \& Ø. Moestrup bloom: migration to the surface as a nutrient acquisition strategy. Harmful Algae 38, 86-94. doi: 10.1016/j.hal.2014.06.001

Heil, C. A., Dixon, L. K., Hall, E., Garrett, M., Lenes, J. M., O’Neil, J. M., et al. (2014c). Blooms of Karenia brevis (Davis) G. Hansen \& Ø. Moestrup on the West Florida Shelf: nutrient sources and potential management strategies based on a multi-year regional study. Harmful Algae 38, 127-140. doi: 10.1016/j.hal. 2014.07.016

Heil, C. A., Revilla, M., Glibert, P. M., and Murasko, S. (2007). Nutrient quality drives differential phytoplankton community composition on the southwest Florida shelf. Limnol. Oceanogr. 52, 1067-1078. doi: 10.4319/lo.2007.52.3.1067

Heil, C. A., Vargo, G. A., Spence, D., Neely, M. B., Merkt, R., Lester, K., et al. (2001). "Nutrient Stoichiometry of a Gymnodinium breve Davis (Gymnodiniales: Dinophyceae) bloom: what limits blooms in oligotrophic environments? In Harmful Algal Blooms 2000," in Intergovernmental Oceanographic Commission of UNESCO 2001, eds G. Hallegraeff, S. I. Blackburn, C. J. Bolch, and R. J. Lewis (Paris: UNESCO), 165-168. 
Heil, D. C. (2009). Karenia brevis monitoring, management, and mitigation for Florida molluscan shellfish harvesting areas. Harmful Algae 8, 608-610. doi: 10.1016/j.hal.2008.11.007

Heisler, J., Glibert, P. M., Burkholder, J. M., Anderson, D. M., Cochlan, W., Dennison, W. C., et al. (2008). Eutrophication and harmful algal blooms: a scientific consensus. Harmful Algae 8, 3-13. doi: 10.1016/j.hal.2008.08.006

Hereman, T. C., and Bittencourt-Oliveira, M. D. C. (2012). Bioaccumulation of microcystins in lettuce. J. Phycol. 48, 1535-1537. doi: 10.1111/jpy.12006

Herman-Mercer, N. M., Matkin, E., Laituri, M. J., Toohey, R. C., Massey, M., Elder, K., et al. (2016). Changing times, changing stories: generational differences in climate change perspectives from four remote indigenous communities in Subarctic Alaska. Ecol. Soc. 21:28. doi: 10.5751/ES-08463-210328

Hernández-Becerril, D. U. (1998). Species of the planktonic diatom genus Pseudonitzschia of the Pacific coasts of Mexico. Hydrobiologia 379, 77-84. doi: 10.1023/ A:1003471828302

Hinga, K. R. (1992). Co-occurrence of dinoflagellate blooms and high $\mathrm{pH}$ in marine enclosures. Mar. Ecol. Prog. Ser. 86, 181-187. doi: 10.3354/meps087181

Hinga, K. R. (2002). Effects of $\mathrm{pH}$ on coastal marine phytoplankton. Mar. Ecol. Prog. Ser. 238, 281-300. doi: 10.3354/meps238281

Hitzfeld, B. C., Höger, S. J., and Dietrich, D. R. (2000). Cyanobacterial toxins: removal during drinking water treatment, and human risk assessment. Environ. Health Perspect. 108, 113-122. doi: 10.2307/3454636

Hoagland, P., and Scatasta, S. (2006). "The economic effects of harmful algal blooms," in Ecology of Harmful Algae. Ecological Studies (Analysis and Synthesis), eds E. Granéli and J. T. Turner (Berlin: Springer), 391-402. doi: 10.1007/978-3-540-32210-8_30

Hoagland, P., Anderson, D. M., Kaoru, Y., and White, A. W. (2002). The economic effects of harmful algal blooms in the United States: estimates, assessment issues, and information needs. Estuaries 25, 819-837. doi: 10.1007/bf02804908

Hoagland, P., Jin, D., Beet, A., Kirkpatrick, B., Reich, A., Ullmann, S., et al. (2014). The human health effects of Florida Red Tide (FRT) blooms: an expanded analysis. Environ. Int. 68, 144-153. doi: 10.1016/j.envint.2014.03.016

Hoagland, P., Jin, D., Polansky, L. Y., Kirkpatrick, B., Kirkpatrick, G., Fleming, L. E., et al. (2009). The costs of respiratory illnesses arising from Florida Gulf Coast Karenia brevis blooms. Environ. Health Perspect. 117, 1239-1243. doi: 10.1289/ehp.0900645

Hoagland, P., Kirkpatrick, B., Jin, D., Kirkpatrick, G., Fleming, L. E., Ullmann, S. G., et al. (2020). Lessening the hazards of florida red tides: a common sense approach. Front. Mar. Sci. 7:538. doi: 10.3389/fmars.2020.00538

Hoeger, S. J., Hitzfeld, B. C., and Dietrich, D. R. (2005). Occurrence and elimination of cyanobacterial toxins in drinking water treatment plants. Toxicol. Appl. Pharmacol. 203, 231-242. doi: 10.1016/j.taap.2004.04.015

Hoffman, L. (1999). Marine cyanobacteria in tropical regions: diversity and ecology. Eur. J. Phycol. 34, 371-379. doi: 10.1080/09670269910001736432

Holmes, M. J. (1998). Gambierdiscus yasumotoi sp. nov. (Dinophyceae), a toxic benthic dinoflagellate from southeastern Asia. J. Phycol. 34, 661-668. doi: 10. 1046/j.1529-8817.1998.340661.x

Howard, M. D. A., Cochlan, W. P., Ladizinsky, N., and Kudela, R. M. (2007). Nitrogenous preference of toxigenic Pseudo-nitzschia australis (Bacillariophyceae) from field and laboratory experiments. Harmful Algae 6, 206-217. doi: 10.1016/j.hal.2006.06.003

$\mathrm{Hu}, \mathrm{C}$., and Feng, L. (2014). GOES imager shows diurnal changes of a trichodesmium erythraeum bloom on the West Florida shelf. IEEE Geosci. Remote Sens. Lett. 11, 1428-1432. doi: 10.1109/lgrs.2013.2294753

Hu, C., Cannizzaro, J., Carder, K. L., Muller-Karger, F. E., and Hardy, R. (2010). Remote detection of Trichodesmium blooms in optically complex coastal waters: examples with MODIS full-spectral data. Remote Sens. Environ. 114, 2048-2058. doi: 10.1016/j.rse.2010.04.011

Hu, C., Muller-Karger, F. E., and Swarzenski, P. W. (2006). Hurricanes, submarine groundwater discharge, and Florida's red tides. Geophys. Res. Lett. 33:L11601. doi: 10.1029/2005GL025449

Hubbard, K. A., Bruzek, S. E., O’Dea, S., Farrell, A., Markley, Henschen, L., et al. (2015). "Complex bloom dynamics revealed by genetic characterization of US Atlantic and Gulf of Mexico Pseudo-nitzschia communities," in Eighth Symposium on Harmful Algae in the U.S., Nov. 15, 19, 2015, Long Beach California, 75. Available online at: https://www.whoi.edu/fileserver.do?id= 235844\&pt=2\&p=241409
Hubbard, K. A., Olson, C. E., and Armbrust, E. V. (2014). Molecular characterization of Pseudo-nitzschia community structure and species ecology in a hydrographically complex estuarine system (Puget Sound, Washington, USA). Mar. Ecol. Prog. Ser. 507, 39-55. doi: 10.3354/meps 10820

Hubbard, K., Anderson, D., Archer, S., Berger, H., Brosnahan, M., Chadwick, C., et al. (2017). "Synergistic characterization of Pseudo-nitzschia communities during unprecedented domoic acid events," in Proceedings of the Ninth Symposium on Harmful Algae in the U.S, Baltimore, MD.

Humm, H. J. (1973). "Benthic algae of the eastern Gulf of Mexico," in A Summary of Knowledge of the Eastern Gulf of Mexico, eds J. Jones, R. Ring, M. Rinkel and R. Smith (St. Petersburg, FL: State University System of Florida Institute of Oceanography), 1-15.

Humphries, P., and Winemiller, K. O. (2009). Historical impacts on river fauna, shifting baselines, and challenges for restoration. Bioscience 59, 673-684. doi: 10.1525/bio.2009.59.8.9

Huntley, M., Sykes, P., Rohan, S., and Marin, V. (1986). Chemically-mediated rejection of dinoflagellate prey by the copepods Calanus pacificus and Paracalanus parvus: mechanism, occurrence and significance. Mar. Ecol. Prog. Ser. 28, 105-120. doi: 10.3354/meps028105

Ibelings, B. W., Backer, L. C., Kardinaal, W. E. A., and Chorus, I. (2014). Current approaches to cyanotoxin risk assessment and risk management around the globe. Harmful Algae 40, 63-74. doi: 10.1016/j.hal.2014.10.002

Indelicato, S. R., and Watson, D. A. (1986). Identification of the photosynthetic pigments of the tropical benthic dinoflagellate Gambierdiscus toxicus. Mar. Fish. Rev. 48, 44-47.

Ingle, R. M., and Martin, D. F. (1971). Prediction of the Florida red tide by means of the iron index. Environ. Lett. 3, 69-74. doi: 10.1080/00139307109434970

International Agency for Research on Cancer Working Group on the Evaluation of the Carcinogenic Risks to Humans (2010). IARC Monographs on the Evaluation of Carcinogenic Risks to Humans, Volume 94, Ingested Nitrate and Nitrite, and Cyanobacterial Peptide Toxins: This Publication Represents the Views and Expert Opinions of an IARC Working Group on the Evaluation of Carcinogenic Risks to Humans. (Lyon: IARC), 14-21.

Ivey, J. E., Wolny, J. L., Heil, C. A., Murasko, S. M., Brame, J. A., and Parks, A. A. (2020). Urea inputs drive Picoplankton Blooms in Sarasota Bay, Florida, USA. Water 12:2755. doi: 10.3390/w12102755

Jaffé, R., Boyer, J., Lu, X., Maie, N., Yang, C., Scully, N., et al. (2004). Source characterization of dissolved organic matter in a subtropical mangrovedominated estuary by fluorescence analysis. Mar. Chem. 84, 195-210. doi: 10 . 1016/j.marchem.2003.08.001

Jang, M., Berthold, D. E., Yu, Z., Silva-Sanchez, C., Laughinghouse, Iv, H. D., et al. (2020). Atmospheric progression of microcystin-LR from cyanobacterial aerosols. Environ. Sci. Technol. Lett. 7, 740-745. doi: 10.1021/acs.estlett. 0c00464

Janowitz, G. S., and Kamykowski, D. (2006). Modeled Karenia brevis accumulation in the vicinity of a coastal nutrient front. Mar. Ecol. Prog. Ser. 314, 49-59. doi: $10.3354 / \operatorname{meps} 314049$

Janssen, E. M.-L. (2019). Cyanobacterial peptides beyond microcystins-a review on co-occurrence, toxicity, and challenges for risk assessment. Water Res. 151, 488-499. doi: 10.1016/j.watres.2018.12.048

Jensen, A. C. (1975). "The economic halo of a HAB," in Proceedings of the 1st International Conference on Toxic Dinoflagellate Blooms, ed. V. R. LoCicero (Boston, MA: The Massachusetts Science and Technology Foundation).

Jeong, H. J., Park, J. Y., Nho, J. H., Park, M. O., et al. (2005). Feeding by redtide dinoflagellates on the cyanobacterium Synechococcus. Aquat. Microb. Ecol. 41.131-143.

Jiang, L., and Ilag, L. L. (2014). Detection of endogenous BMAA in dinoflagellate (Heterocapsa triquetra) hints at evolutionary conservation and environmental concern. PubRaw Sci. 1, 1-8.

Jiang, L., Eriksson, J., Lage, S., Jonasson, S., Shams, S., Mehine, M., et al. (2014). Diatoms: a novel source for the neurotoxin BMAA in aquatic environments. PLoS One 9:e84578. doi: 10.1371/journal.pone.0106695

Johns, E. M., Lumpkin, R., Putman, N. F., Smith, R. H., Muller-Karger, F. E., RuedaRoa, D. T., et al. (2020). The establishment of a pelagic Sargassum population in the tropical Atlantic: biological consequences of a basin-scale long distance dispersal event. Prog. Oceanogr. 182:102269. doi: 10.1016/j.pocean.2020. 102269 
Judice, T. J., Widder, E. A., Falls, W. H., Avouris, D. M., Cristiano, D. J., and Ortiz, J. D. (2020). Field-validated detection of Aureoumbra lagunensis brown tide blooms in the Indian River Lagoon, Florida using Sentinel-3A OLCI and ground-based hyperspectral spectroradiometers. GeoHealth 4:e2019GH000238. doi: 10.1029/2019GH000238

Kamykowski, D., Milligan, E. J., and Reed, R. E. (1998). Relationships between geotaxis/phototaxis and diel vertical migration in autotrophic dinoflagellates. J. Plankton Res. 20, 1781-1796. doi: 10.1093/plankt/20.9.1781

Kang, Y., and Gobler, C. J. (2018). The brown tide algae, Aureococcus anophagefferens and Aureoumbra lagunensis (Pelagophyceae), allelopathically inhibit the growth of competing microalgae during harmful algal blooms. Limnol. Oceanogr. 63, 985-1003. doi: 10.1002/lno.10714

Kang, Y., Koch, F., and Gobler, C. J. (2015). The interactive roles of nutrient loading and zooplankton grazing in facilitating the expansion of harmful algal blooms caused by the pelagophyte, Aureoumbra lagunensis, to the Indian River Lagoon, FL, USA. Harmful Algae 49, 162-173. doi: 10.1016/j.hal.2015.09.005

Kang, Y., Tang, Y. Z., Taylor, G. T., and Gobler, C. J. (2017). Discovery of a resting stage in the harmful, brown-tide-causing pelagophyte, Aureoumbra lagunensis: a mechanism potentially facilitating recurrent blooms and geographic expansion. J. Phycol. 53, 118-130. doi: 10.1111/jpy.12485

Kavanaugh, K. E., Derner, K., Fisher, K. M., David, E. E. P., Urizar, C., and Merlini, R. (2013). Assessment of the eastern Gulf of Mexico Harmful Algal Bloom Operational Forecast System (GOMX HAB-OFS): A Comparative Analysis of Forecast Skill and Utilization from October 1, 2004 to April 30, 2008. Washington, DC: NOAA. doi: 10.13140/RG.2.1.2160.2169

Kemp, D. W., Oakley, C. A., Thornhill, D. J., Newcomb, L. A., Schmidt, G. W., and Fitt, W. K. (2011). Catastrophic mortality on inshore coral reefs of the Florida Keys due to severe low-temperature stress. Glob. Change Biol. 17, 3468-3477. doi: 10.1111/j.1365-2486.2011.02487.x

Kerbrat, A. S., Amzil, Z., Pawlowiez, R., Golubic, S., Sibat, M., Darius, H. T., et al. (2011). First evidence of palytoxin and 42-hydroxy-palytoxin in the marine cyanobacterium Trichodesmium. Mar. Drugs 9, 543-560. doi: 10.3390/ md9040543

Kibler, S. R., Davenport, E. D., Tester, P. A., Hardison, D. R., Holland, W. C., and Litaker, R. W. (2017). Gambierdiscus and Fukuyoa species in the greater Caribbean: regional growth projections for ciguatera-associated dinoflagellates. Ecol. Model. 360, 204-218. doi: 10.1016/j.ecolmodel.2017.07.007

Killberg-Thoreson, L., Sipler, R. E., Heil, C. A., Garrett, M. J., Roberts, Q. N., and Bronk, D. A. (2014). Nutrients released from decaying fish support microbial growth in the eastern Gulf of Mexico. Harmful Algae 38, 40-49. doi: 10.1016/j. hal.2014.04.006

Kinley-Baird, C., Calomeni, A., Berthold, D. E., Lefler, F. W., Barbosa, M., Rodgers, J. H., et al. (2021). Laboratory-scale evaluation of algaecide effectiveness for control of microcystin-producing cyanobacteria from Lake Okeechobee, Florida (USA). Ecotoxicol. Environ. Saf. 207:111233. doi: 10.1016/j.ecoenv.2020. 111233

Kirkpatrick, B., Bean, J. A., Fleming, L. E., Kirkpatrick, G., Grief, L., Nierenberg, K., et al. (2010). Gastrointestinal emergency room admissions and Florida red tide blooms. Harmful Algae 9, 82-86. doi: 10.1016/j.hal.2009.08.005

Kirkpatrick, B., Currier, R., Nierenberg, K., Reich, A., Backer, L. C., Stumpf, R., et al. (2008). Florida red tide and human health: a pilot beach conditions reporting system to minimize human exposure. Sci. Total Environ. 402, 1-8. doi: 10.1016/j.scitotenv.2008.03.032

Kirkpatrick, B., Fleming, L. E., Backer, L. C., Bean, J. A., Tamer, R., Kirkpatrick, G., et al. (2006). Environmental exposures to Florida red tides: effects on emergency room respiratory diagnoses admissions. Harmful Algae 5, 526-533. doi: 10.1016/j.hal.2005.09.004

Kirkpatrick, B., Fleming, L. E., Squicciarini, D., Backer, L. C., Clark, R., Abraham, W., et al. (2004). Literature review of Florida red tide: implications for human health effects. Harmful Algae 3, 99-115. doi: 10.1016/j.hal.2003.08.005

Kirkpatrick, B., Kohler, K., Byrne, M. M., and Studts, J. (2014). Florida red tide knowledge and risk perception: Is there a need for tailored messaging. Harmful Algae 32, 27-32. doi: 10.1016/j.hal.2013.09.008

Kirpenko, Y. A., Sirenko, L., and Kirpenko, N. (1981). "Some aspects concerning remote after-effects of blue-green algae toxin impact on warm-blooded animals," in The Water Environment, ed. W. W. Carmichael (Boston, MA: Springer), 257-269. doi: 10.1007/978-1-4613-3267-1_19
Kleindinst, J. L., and Anderson, D. M. (2004). "Internet-based communication tools for dissemination of information on harmful algal blooms (HABs)," in Harmful Algae Management and Mitigation. Asia-Pacific Economic Cooperation, (Singapore: APEC Publication), 97-101.

Knap, A., Dewailly, É., Furgal, C., Galvin, J., Baden, D., Bowen, R. E., et al. (2002). Indicators of ocean health and human health: developing a research and monitoring framework. Environ. Health Perspect. 110, 839-845. doi: 10.1289/ ehp.02110839

Knutson, T. R., McBride, J. L., Chan, J., Emanuel, K., Holland, G., Landsea, C., et al. (2010). Tropical cyclones and climate change. Nat. Geosci. 3, 157-163.

Koch, F., Kang, Y., Villareal, T. A., Anderson, D., and Gobler, C. (2014). A novel immunofluorescence flow cytometry technique detects the expansion of brown tides caused by Aureoumbra lagunensis to the Caribbean Sea. Appl. Environ. Microbiol. 80, 4947-4957. doi: 10.1128/AEM.00888-14

Komárek, J., Zapomělová, E., Šmarda, J., Kopecký, J., Rejmánková, E., Woodhouse, J., et al. (2013). Polyphasic evaluation of Limnoraphis robusta, a water-bloom forming cyanobacterium from Lake Atitlán, Guatemala, with a description of Limnoraphis gen. nov. Fottea 13, 39-52. doi: 10.5507/fot.2013.004

Kotaki, Y., Koike, K., Yoshida, M., Thuoc, C. V., et al. (2000). Domoic acid production in Nitzschia sp. isolated from a shrimp-culture pond in Do Son, Vietnam. J. Phycol. 36, 1057-1060. doi: 10.1046/j.1529-8817.2000.99209.x

Krahl, P. L. (2009). Harmful Algal bloom-associated marine toxins: a risk assessment framework. Arch. Environ. Occup. Health 64, 129-134. doi: 10.3200/ AEOH.64.2.129-134

Kramer, B. J., Davis, T. W., Meyer, K. A., Rosen, B. H., Goleski, J. A., Dick, G. J., et al. (2018). Nitrogen limitation, toxin synthesis potential, and toxicity of cyanobacterial populations in Lake Okeechobee and the St. Lucie River Estuary, Florida, during the 2016 state of emergency event. PLoS One 13:e0196278. doi: 10.1371/journal.pone.0196278

Krayesky, D. M., Meave del Castillo, E., Zamudio, E., Norris, J. N., and Fredericq, S. (2009). "Diatoms (Bacillariophyta) of the Gulf of Mexico," in Gulf of Mexico Origin, Waters, and Biota: Volume 1 Biodiversity, eds D. L. Felderr and D. K. Camp (College Station, TX: Texas A\&M University Press), 155-186.

Krimsky, L. S., Phlips, E. J., and Havens, K. (2018). A Response to Frequently Asked Questions about the 2018 Lake Okeechobee, Caloosahatchee and St. Lucie Rivers and Estuaries Algal Blooms. (Gainesville, FL: University of Florida).

Kubanek, J., Hicks, M., Naar, J., and Villareal, T. A. (2005). Does the red tide dinoflagellate Karenia brevis use allelopathy to outcompete other phytoplankton? Limnol. Oceanogr. 50, 883-895. doi: 10.4319/lo.2005.50.3.0883

Kuhar, S. E., Nierenberg, K., Kirkpatrick, B., and Tobin, G. A. (2009). Public perceptions of Florida red tide risks. Risk Anal. Int. J. 29, 963-969. doi: 10. 1111/j.1539-6924.2009.01228.x

Lage, S., Costa, P. R., Moita, T., Eriksson, J., Rasmussen, U., and Rydberg, S. J. (2014). BMAA in shellfish from two Portuguese transitional water bodies suggests the marine dinoflagellate Gymnodinium catenatum as a potential BMAA source. Aquat. Toxicol. 152, 131-138. doi: 10.1016/j.aquatox.2014.03. 029

Landsberg, J. H. (2002). The effects of harmful algal blooms on aquatic organisms. Rev. Fish. Sci. 10, 113-390. doi: 10.1080/20026491051695

Landsberg, J. H., Hall, S., Johannessen, J. N., White, K. D., Conrad, S. M., Abbott, J. P., et al. (2006). Saxitoxin puffer fish poisoning in the United States, with the first report of Pyrodinium bahamense as the putative toxin source. Environ. Health Perspect. 114, 1502-1507. doi: 10.1289/ehp.8998

Landsberg, J. H., Hendrickson, J., Tabuchi, M., Kiryu, Y., Williams, B. J., and Tomlinson, M. C. (2020). A large-scale sustained fish kill in the St. Johns River, Florida: a complex consequence of cyanobacteria blooms. Harmful Algae 92:101771. doi: 10.1016/j.hal.2020.101771

Landsberg, J., Flewelling, L., and Naar, J. (2009). Karenia brevis red tides, brevetoxins in the food web, and impacts on natural resources: decadal advancements. Harmful Algae 8, 598-607. doi: 10.1016/j.hal.2008.11.010

Lapointe, B. E. (1997). Nutrient thresholds for bottom-up control of macroalgal blooms on coral reefs in Jamaica and southeast Florida. Limnol. Oceanogr. 42, 1119-1131. doi: 10.4319/lo.1997.42.5_part_2.1119

Lapointe, B. E., and Bedford, B. J. (2007). Drift rhodophyte blooms emerge in Lee County, Florida, USA: evidence of escalating coastal eutrophication. Harmful Algae 6, 421-437. doi: 10.1016/j.hal.2006. 12.005 
Lapointe, B. E., and Clark, M. W. (1992). Nutrient inputs from the watershed and coastal eutrophication in the Florida Keys. Estuaries 15, 465-476. doi: $10.2307 / 1352391$

Lapointe, B. E., Brewton, R. A., Herren, L. W., Porter, J. W., and Hu, C. (2019). Nitrogen enrichment, altered stoichiometry, and coral reef decline at Looe Key, Florida Keys, USA: a 3-decade study. Mar. Biol. 166:108.

Lapointe, B. E., Brewton, R. A., Herren, L. W., Porter, J. W., Hu, C., and Cannizzaro, J. P. (2020). Sound science, not politics, must inform restoration of Florida Bay and the coral reefs of the Florida Keys. Mar. Biol. 167, 1-12.

Lapointe, B. E., Herren, L. W., and Paule, A. L. (2017). Septic systems contribute to nutrient pollution and harmful algal blooms in the St. Lucie Estuary, Southeast Florida, USA. Harmful Algae 70, 1-22. doi: 10.1016/j.hal.2017. 09.005

Lapointe, B. E., Herren, L. W., Debortoli, D. D., and Vogel, M. A. (2015). Evidence of sewage-driven eutrophication and harmful algal blooms in Florida's Indian River Lagoon. Harmful Algae 43, 82-102. doi: 10.1016/j.hal.2015.01.004

Lapointe, B. E., Tomasko, D. A., and Matzie, W. R. (1994). Eutrophication and trophic state classification of seagrass communities in the Florida Keys. Bull. Mar. Sci. 54, 696-717.

Lapointe, B., and Thacker, K. (2001). "Community based water quality and coral reef monitoring in the Negril Marine Park, Jamaica," in The Everglades, Florida Bay, and Coral Reefs of the Florida Keys: An Ecological Sourcebook, ed. P. James (Boca Raton, FL: CRC Press), 1002-1022. doi: 10.1201/9781420039412-42

Larkin, S. L., and Adams, C. M. (2007). Red tides and coastal businesses: measuring economic consequences in Florida. Soc. Nat. Res. 20, 849-859.

Lawrence, D. N., Enriquez, M. B., Lumish, R. M., and Maceo, A. (1980). Ciguatera fish poisoning in Miami. JAMA 244, 254-258. doi: 10.1001/jama. 1980.03310030030021

Laws, E. A. (2007). Climate Change, Oceans, and Human Health. Ocean Yearb. Online 21, 129-175.

Lefebvre, K. A., and Robertson, A. (2010). Domoic acid and human exposure risks: a review. Toxicon 56, 218-230.

Lefler, F. W., Barbosa, M., Berthold, D. E., and Laughinghouse, H. D. (2020). Genome Sequences of Two Microcystis aeruginosa (Chroococcales, Cyanobacteria) Strains from Florida (United States) with Disparate Toxigenic Potentials. Microbiol. Resour. Announc. 9:e00844-20. doi: 10.1128/MRA.0084420

Lefler, F. W., Berthold, D. E., and Laughinghouse Iv, H. D. (2021). The occurrence of Affixifilum gen. nov. and Neolyngbya (Oscillatoriaceae) in South Florida (USA), with the description of A. floridanum sp. nov. and N. biscaynensis sp. nov. J. Phycol. 57, 92-110. doi: 10.1111/jpy. 13065

Lehane, L., and Lewis, R. J. (2000). Ciguatera: recent advances but the risk remains. Int. J. Food Microbiol. 61, 91-125. doi: 10.1016/s0168-1605(00)00382-2

Lehman, P. W., Marr, K., Boyer, G. L., Acuna, S., and Teh, S. J. (2013). Longterm trends and causal factors associated with Microcystis abundance and toxicity in San Francisco Estuary and implications for climate change impacts. Hydrobiologia 718, 141-158.

Lehman, R. L., and Wood, T. (1996). "Bacillariophytes (Diatoms)," in Checklist of Species Within Corpus Christi Bay National Estuary Program Study Area: References, Habitats, Distribution and Abundance, Vol. 4, eds J. W. Tunnell Jr. and S. A. Alvarado (Austin, TX: Texas Natural Resource Conservation Commission), 21-31.

Lelong, A., Hégaret, H., Soudant, P., and Bates, S. S. (2012). Pseudonitzschia (Bacillariophyceae) species, domoic acid and amnesic shellfish poisoning: revisiting previous paradigms. Phycologia 51, 168-216. doi: 10.2216/ $11-37.1$

Lenes, J. M., and Heil, C. A. (2010). A historical analysis of the potential nutrient supply from the N2 fixing marine cyanobacterium Trichodesmium spp. to Karenia brevis blooms in the eastern Gulf of Mexico. J. Plankton Res. 32, 1421-1431.

Lenes, J. M., Darrow, B. P., Cattrall, C., Heil, C. A., Callahan, M., Vargo, G. A., et al. (2001). Iron fertilization and the Trichodesmium response on the West Florida shelf. Limnol. Oceanogr. 46, 1261-1277.

Lenes, J. M., Walsh, J., and Darrow, B. P. (2013). Simulating cell death in the termination of Karenia brevis blooms: implications for predicting aerosol toxicity vectors to humans. Mar. Ecol. Prog. Ser. 493, 71-81. doi: 10.3354/ meps 10515
Lester, K. (2005). The Mesozooplankton of the West Florida Shelf: Relationships with Karenia brevis Blooms. Ph. D. dissertation. Tampa, FL: University of South Florida.

Lewis, M. A., Dantin, D. D., Walker, C. C., Kurtz, J. C., and Greene, R. M. (2003). Toxicity of clay flocculation of the toxic dinoflagellate, Karenia brevis, to estuarine invertebrates and fish. Harmful Algae 2, 235-246. doi: 10.1016/S15689883(03)00041-6

Lewis, N. D. (1986). Epidemiology and consequence of ciguatera in the Pacific: a review. Mar. Fish. Rev. 48, 6-13.

Lewis, R. J. (1992). Socioeconomic consequences and management of ciguatera in the Pacific. Bull. Soc. Pathol. Exot. 85, 427-434.

Li, Z., Garrison, B., Ullmann, S. G., Kirkpatrick, B., Fleming, L. E., and Hoagland, P. (2015). Risk in daily newspaper coverage of red tide blooms in Southwest Florida. Appl. Environ. Educ. Commun. 14, 167-177. doi: 10.1080/1533015X. 2015.1067579

Liang, C., and Wang, W. (2015). Response and recovery of rice (Oryza sativa) seedlings to irrigation with microcystin-contaminated water. Environ. Earth Sci. 73, 4573-4580.

Licea, S., Zamudio, M. E., Moreno-Ruiz, J. L., and Luna, R. (2011). A suggested local region in the Southern Gulf of Mexico using a diatom database (19792002) and oceanic hydrographic features. J. Environ. Biol. 32, 443-453.

Liefer, J. D., MacIntyre, H. L., Novoveska, L., Smith, W. L., and Dorsey, C. P. (2009). Temporal and spatial variability in Pseudo-nitzschia spp. in Alabama coastal waters: a "hot spot" linked to submarine groundwater discharge?. Harmful Algae 8, 706-714.

Lin, S., Geng, M., Liu, X., Tan, J., and Yang, H. (2016). On the control of Microcystis aeruginosa and Synechococccus species using an algicidal bacterium, Stenotrophomonas F6, and its algicidal compounds cyclo-(Gly-Pro) and hydroquinone. J. Appl. Phycol. 28, 345-355. doi: 10.1007/s10811-015-0549-x

Lipp, E., and Rose, J. (1997). The role of seafood in foodborne diseases in the United States of America. Rev. Sci. Tech. Off. Int. Epizoot. 16, 620-640. doi: 10.20506/rst.16.2.1048

Litaker, R. W., Holland, W. C., Hardison, D. R., Pisapia, F., Hess, P., Kibler, S. R., et al. (2017). Ciguatoxicity of Gambierdiscus and Fukuyoa species from the Caribbean and Gulf of Mexico. PLoS One 12:e0185776. doi: 10.1371/journal. pone.0185776

Litaker, R. W., Vandersea, M. W., Faust, M. A., Kibler, S. R., Chinain, M., Holmes, M. J., et al. (2009). Taxonomy of Gambierdiscus including four new species, Gambierdiscus caribaeus, Gambierdiscus carolinianus, Gambierdiscus carpenteri and Gambierdiscus ruetzleri (Gonyaulacales, Dinophyceae). Phycologia 48, 344390. doi: 10.2216/07-15.1

Litaker, R. W., Vandersea, M. W., Faust, M. A., Kibler, S. R., Nau, A. W., Holland, W. C., et al. (2010). Global distribution of ciguatera causing dinoflagellates in the genus Gambierdiscus. Toxicon 56, 711-730. doi: 10.1016/j.toxicon.2010.05. 017

Liu, H., and Buskey, E. J. (2000). Hypersalinity enhances the production of extracellular polymeric substance (EPS) in the Texas brown tide alga, Aureoumbra lagunensis (Pelagophyceae). J. Phycol. 36, 71-77.

Liu, H., Laws, E. A., Villareal, T. A., and Buskey, E. J. (2001). Nutrientlimited growth of Aureoumbra lagunensis (Pelagophyceae), with implications for its capability to outgrow other phytoplankton species in phosphatelimited environments. J. Phycol. 37, 500-508. doi: 10.1046/j.1529-8817.2001. 037004500.x

Liu, Y., Weisberg, R. H., Vignudelli, S., Roblou, L., and Merz, C. R. (2012). Comparison of the X-TRACK altimetry estimated currents with moored ADCP and HF radar observations on the West Florida Shelf. Adv. Space Res. 50, 1085-1098. doi: 10.1016/j.asr.2011.09.012

Loftin, K. A., Graham, J. L., Hilborn, E. D., Lehmann, S. C., Meyer, M. T., Dietze, J. E., et al. (2016). Cyanotoxins in inland lakes of the United States: occurrence and potential recreational health risks in the EPA national lakes assessment 2007. Harmful Algae 56, 77-90.

Longhurst, A., Sathyendranath, S., Platt, T., and Caverhill, C. (1995). An estimate of global primary production in the ocean from satellite radiometer data. J. Plankton Res. 17, 1245-1271. doi: 10.1093/plankt/17.6.1245

Lopez, C. B., Jewett, E. B., Dortch, Q., Walton, B. T., and Hudnell, H. K. (2008). Scientific Assessment of Freshwater Harmful Algal Blooms. Washington, DC: Interagency Working Group on Harmful Algal Blooms, Hypoxia, and Human Health of the Joint Subcommittee on Ocean Science and Technology. 
Lopez, C. B., Karim, A., Murasko, S., Marot, M., Smith, C. G., and Corcoran, A. A. (2019). Temperature mediates secondary dormancy in resting cysts of Pyrodinium bahamense (Dinophyceae). J. Phycol. 55, 924-935. doi: 10.1111/jpy. 12883

Lopez, C. B., Smith, C. G., Marot, M. E., Karlen, D. J., and Corcoran, A. A. (2015). "The role of seedbeds in Pyrodinium bahamense bloom dynamics in Tampa Bay," in Proceedings of the Tampa Bay Area Scientific Information Symposium BASIS 6, ed. M. Burke (St. Petersburg, FL: Tampa Bay Estuary Program).

Love, D. C., Asche, F., Conrad, Z., Young, R., Harding, J., Nussbaumer, E. M., et al. (2020). Food sources and expenditures for seafood in the United States. Nutrients 12:1810.

Lundholm, N., and Moestrup, Ø. (2000). Morphology of the marine diatom Nitzschia navis-varingica, sp. nov. (Bacillariophyceae), another producer of the neurotoxin domoic acid. J. Phycol 36, 1162-1174. doi: 10.1046/j.1529-8817. 2000.99210.x

Lundholm, N., Hansen, P. J., and Kotaki, Y. (2004). Effect of pH on growth and domoic acid production by potentially toxic diatoms of the genera Pseudonitzschia and Nitzschia. Mar. Ecol. Prog. Ser. 273, 1-15.

Lundholm, N., Hasle, G. R., Fryxell, G. A., and Hargraves, P. E. (2002). Morphology, phylogeny and taxonomy of species within the Pseudo-nitzschia americana complex (Bacillariophyceae) with descriptions of two new species, Pseudo-nitzschia brasiliana and Pseudo-nitzschia linea. Phycologia 41, 480-497.

Lynch, T., and Phlips, E. (2000). Filtration of the bloom-forming cyanobacteria Synechococcus by three sponge species from Florida Bay, USA. Bull. Mar. Sci. 67, 923-936.

Lyytimäki, J. (2013). Nature's nocturnal services: light pollution as a nonrecognized challenge for ecosystem services research and management. Ecosyst. Serv. 3, e44-e48.

Machado, J., Campos, A., Vasconcelos, V., and Freitas, M. (2017). Effects of microcystin-LR and cylindrospermopsin on plant-soil systems: a review of their relevance for agricultural plant quality and public health. Environ. Res. 153, 191-204. doi: 10.1016/j.envres.2016.09.015

MacIntyre, H. L., Stutes, A. L., Smith, W. L., Dorsey, C. P., Abraham, A., and Dickey, R. W. (2011). Environmental correlates of community composition and toxicity during a bloom of Pseudo-nitzschia spp. in the northern Gulf of Mexico. J. Plankton Res. 33, 273-295. doi: 10.1093/plankt/fbq146

Maclean, J. (1989). Indo-Pacific red tides, 1985-1988. Mar. Pollut. Bull. 20, 304310. doi: 10.1016/0025-326X(89)90152-5

Maclean, J. L. (1977). Observations on Pyrodinium bahamense Plate, a toxic dinoflagellate in Papua New Guinea. Agric. J. 24, 131-138.

Manzello, D. P., Berkelmans, R., and Hendee, J. C. (2007). Coral bleaching indices and thresholds for the Florida reef tract, Bahamas, and St. Croix, US Virgin Islands. Mar. Pollut. Bull. 54, 1923-1931. doi: 10.1016/j.marpolbul.2007.08.009

Marsooli, R., Lin, N., Emanuel, K., and Feng, K. (2019). Climate change exacerbates hurricane flood hazards along US Atlantic and Gulf Coasts in spatially varying patterns. Nat. Commun. 10:1038.

Matsuoka, K., Fukuyo, Y., and Gonzales, C. L. (1989). "A new finding of cysts of Pyrodinium bahamense var. compressum from Samar Sea, Philippines," in Red Tides: Biology, Environmental Sciences and Toxicology, eds T. Okaichi, D. M. Anderson, and T. Nemoto (Amsterdam: Elsevier Science Publishing Co), 299-302.

Mayali, X., and Doucette, G. J. (2002). Microbial community interactions and population dynamics of an algicidal bacterium active against Karenia brevis (Dinophyceae). Harmful Algae 1, 277-293. doi: 10.1016/S1568-9883(02)00032$\mathrm{X}$

McElhiney, J., Lawton, L. A., and Leifert, C. (2001). Investigations into the inhibitory effects of microcystins on plant growth, and the toxicity of plant tissues following exposure. Toxicon 39, 1411-1420. doi: 10.1016/S00410101(01)00100-3

McGillicuddy, D. Jr. (2010). Models of harmful algal blooms: conceptual, empirical, and numerical approaches. J. Mar. Syst. 83, 105-107. doi: 10.1016/j.jmarsys. 2010.06.008

McGlathery, K. J. (1995). Nutrient and grazing influences on a subtropical seagrass community. Mar. Ecol. Prog. Ser. 122, 239-252.

McGregor, G. B., and Sendall, B. C. (2015). Phylogeny and toxicology of Lyngbya wollei (Cyanobacteria, Oscillatoriales) from north-eastern Australia, with a description of Microseira gen. nov. J. Phycol. 51, 109-119. doi: 10.1111/jpy. 12256
McLaughlin, J. A., and Zahl, P. A. (1961). In vitro culture of Pyrodinium. Science $134,1878$.

McMichael, A. J., Woodruff, R. E., and Hales, S. (2006). Climate change and human health: present and future risks. Lancet 367, 859-869.

Medina, M., Huffaker, R., Jawitz, J. W., and Muñoz-Carpena, R. (2020). Seasonal dynamics of terrestrially sourced nitrogen influenced Karenia brevis blooms off Florida's southern Gulf Coast. Harmful Algae 98:101900. doi: 10.1016/j.hal.2020. 101900

Metcalf, J. S., and Codd, G. A. (2012). "Cyanotoxins," in Ecology of Cyanobacteria II, ed. B. A. Whitton (Berlin: Springer), 651-675.

Metcalf, J. S., Banack, S. A., Wessel, R. A., Lester, M., Pim, J. G., Cassani, J. R., et al. (2021). Toxin analysis of freshwater cyanobacterial and Marine Harmful Algal Blooms on the West Coast of Florida and Implications for Estuarine Environments. Neurotox. Res. 39, 27-35. doi: 10.1007/s12640-02000248-3

Michalak, A. M., Anderson, E. J., Beletsky, D., Boland, S., Bosch, N. S., Bridgeman, T. B., et al. (2013). Record-setting algal bloom in Lake Erie caused by agricultural and meteorological trends consistent with expected future conditions. Proc. Natl. Acad. Sci. U.S.A. 110, 6448-6452. doi: 10.1073/pnas. 1216006110

Milian, A., Nierenberg, K., Fleming, L. E., Bean, J. A., Wanner, A., Reich, A., et al. (2007). Reported respiratory symptom intensity in asthmatics during exposure to aerosolized Florida red tide toxins. J. Asthma 44, 583-587. doi: $10.1080 / 02770900701539251$

Miller, A., and Russell, C. (2017). Food crops irrigated with cyanobacteriacontaminated water: an emerging public health issue in Canada. Environ. Health Rev. 60, 58-63. doi: 10.5864/d2017-021

Millie, D. F., Schofield, O. M., Kirkpatrick, G. J., Johnsen, G., Tester, P. A., and Vinyard, B. T. (1997). Detection of harmful algal blooms using photopigments and absorption signatures: a case study of the Florida red tide dinoflagellate, Gymnodinium breve. Limnol. Oceangr. 42, 1240-1251. doi: 10.4319/lo.1997.42. 5_part_2.1240

Milligan, K. E., Marquez, B. L., Williamson, R. T., and Gerwick, W. H. (2000). Lyngbyabellin B, a toxic and antifungal secondary metabolite from the marine cyanobacterium Lyngbya majuscula. J. Nat. Prod. 63, 1440-1443. doi: 10.1021/ np000133y

Mines, D., Stahmer, S., and Shepherd, S. M. (1997). Poisonings: food, fish, shellfish. Emerg. Med. Clin. North. Am. 15, 157-177. doi: 10.1016/s0733-8627(05)702893

Mohamed, Z. A., and Al Shehri, A. M. (2009). Microcystins in groundwater wells and their accumulation in vegetable plants irrigated with contaminated waters in Saudi Arabia. J. Hazard. Mater. 172, 310-315. doi: 10.1016/j.jhazmat.2009. 07.010

Mondo, K., Glover, W. B., Murch, S. J., Liu, G., Cai, Y., Davis, D. A., et al. (2014). Environmental neurotoxins $\beta$-N-methylamino-l-alanine (BMAA) and mercury in shark cartilage dietary supplements. Food Chem. Toxicol. 70, 26-32. doi: 10.1016/j.fct.2014.04.015

Mondo, K., Hammerschlag, N., Basile, M., Pablo, J., Banack, S. A., and Mash, D. C. (2012). Cyanobacterial neurotoxin $\beta-\mathrm{N}$-methylamino-L-alanine (BMAA) in shark fins. Mar. Drugs 10, 509-520.

Moore, S. K., Trainer, V. L., Mantua, N. J., Parker, M. S., Laws, E. A., Backer, L. C., et al. (2008). Impacts of climate variability and future climate change on harmful algal blooms and human health. Environ. Health 7(SUPPL. 2):S4.

Morand, P., and Briand, X. (1996). Excessive growth of macroalgae: a symptom of environmental disturbance. Bot. Mar. 39, 491-516. doi: 10.1515/botm.1996.39. $1-6.491$

Moreno, J. L., Licea, S., and Santoyo, H. (1996). Diatomeas del Golfo de California. La Paz: Universidad Autonoma de Baja California Sur.

Moreno-Gutiérrez, S. P. (2008). Estudio Morfológico y Taxonómico de Diatomeas Planctónicas del Género Pseudo-nitzschia Peragallo (Bacillariophycidae) en el Golfo de Tehuantepec, México. Tesis de Licenciatura. (México: UNAM), 61.

Morgan, K. L., Larkin, S. L., and Adams, C. M. (2009). Firm-level economic effects of HABS: a tool for business loss assessment. Harmful Algae 8, 212-218. doi: 10.1016/j.hal.2008.05.002

Morgan, K. L., Larkin, S. L., and Adams, C. M. (2010). Red tides and participation in marine-based activities: estimating the response of Southwest Florida residents. Harmful Algae 9, 333-341. doi: 10.1016/j.hal.2009. 12.004 
Morquecho, L. (2008). Morphology of Pyrodinium bahamense Plate (Dinoflagellata) near Isla San Jose, Gulf of California, Mexico. Harmful Algae 7, 664-670.

Morton, S. L., Norris, D. R., and Bomber, J. W. (1992). Effect of temperature, salinity and light intensity on the growth and seasonality of toxic dinoflagellates associated with ciguatera. J. Exp. Mar. Biol. Ecol.157, 79-90. doi: 10.1016/00220981(92)90076-M

Moss, B., Kosten, S., Meerhoff, M., Battarbee, R. W., Jeppesen, E., Mazzeo, N., et al. (2011). Allied attack: climate change and eutrophication. Inland Waters 1, 101-105.

Mulholland, M. R., Bernhardt, P. W., Heil, C. A., Bronk, D. A., and O'Neil, J. M. (2006). Nitrogen fixation and release of fixed nitrogen by Trichodesmium spp. in the Gulf of Mexico. Limnol. Oceanogr. 51, 1762-1776. doi: 10.4319/lo.2006. 51.4.1762

Mulholland, M. R., Heil, C. A., Bronk, D. A., O'Neil, J. M., and Bernhardt, P. (2002). "Does nitrogen regeneration from the N2 fixing cyanobacteria Trichodesmium spp. fuel Karenia brevis blooms in the Gulf of Mexico?", in Harmful Algae, eds K. A. Steidinger, J. H. Landsberg, C. R. Tomas and G. A. Vargo (St. Petersburg, FL: Florida Fish and Wildlife Conservation Commission), 47-49.

Mulholland, M., Bernhardt, P., Ozmon, I., Procise, L., Garrett, M., O’Neil, J., et al. (2014). Contribution of diazotrophy to nitrogen inputs supporting Karenia brevis blooms in the Gulf of Mexico. Harmful Algae 38, 20-29. doi: 10.1016/ j.hal.2014.04.004

Murdock, J. F. (1954). A Preliminary Survey of the Effects of Releasing Water from Lake Okeechobee through the St. Lucie and Caloosahatchee Estuaries. Final Report to the Corps of Engineers, U.S. Army. (Coral Gables, FL: University of Miami), 84 .

Muro, M., Victor, D., and Whiton, J. (2019). How the Geography of Climate Damage Could Make the Politics Less Polarizing. Washington, DC: The Brookings Institution.

Naar, J. P., Flewelling, L. J., Lenzi, A., Abbott, J. P., et al. (2007). Brevetoxins, like ciguatoxins, are potent ichthyotoxic neurotoxins that accumulate in fish. Toxicon 50, 707-723. doi: 10.1016/j.toxicon.2007.06.005

Nabout, J. C., da Silva, Rocha, B., Carneiro, F. M., and Sant'Anna, C. L. (2013). How many species of Cyanobacteria are there? Using a discovery curve to predict the species number. Biodivers. Conserv. 22, 2907-2918. doi: 10.1007/s10531-0130561-x

Nakajima, I., Oshuma, Y., and Yasumoto, T. (1981). Toxicity of benthic dinoflagellates in Okinawa. Bull. Japan. Soc. Sci. Fish 47, 1029-1033.

National Research Council [NRC] (1983). "Risk Assessment in the Federal Government: Managing the Process." Committee on the Institutional Means for Assessment of Risks to Public Health. Washington, D.C: National Academy Press.

Nierenberg, K., Hollenbeck, J., Fleming, L. E., Stephan, W., Reich, A., Backer, L. C., et al. (2011). Frontiers in outreach and education: the Florida red tide experience. Harmful Algae 10, 374-380. doi: 10.1016/j.hal.2011.01.004

Nierenberg, K., Kirner, K., Hoagland, P., Ullmann, S., LeBlanc, W. G., Kirkpatrick, G., et al. (2010). Changes in work habits of lifeguards in relation to Florida red tide. Harmful Algae 9, 419-425. doi: 10.1016/j.hal.2010.02.005

Nordlie, F. G. (1976). Plankton communities of three central Florida lakes. Hydrobiologia 48, 65-78. doi: 10.1007/BF00033492

O’Dea, S. N. (2012). Occurrence, Toxicity, and Diversity of Pseudo-nitzschia in Florida Coastal Waters. Master's thesis. Tampa, FL: University of South Florida.

O’Dea, S. N., Flewelling, L. J., Wolny, J., Brame, J., Henschen, K., Scott, P., et al. (2013). "Florida's first shellfish closure due to domoic acid," in Proceedings of the Seventh Symposium on Harmful Algae in the U.S, Sarasota, FL.

O’Neil, J. M., Davis, T. W., Burford, M. A., and Gobler, C. J. (2012). The rise of harmful cyanobacteria blooms: the potential roles of eutrophication and climate change. Harmful Algae 14, 313-334. doi: 10.1016/j.hal.2011.10.027

Obeysekera, J., Irizarry, M., Park, J., Barnes, J., and Dessalegne, T. (2011). Climate change and its implications for water resources management in south Florida. Stochast. Environ. Res. Risk Assess. 25, 495-516. doi: 10.1007/s00477-010-04188

Oehrle, S., Rodriguez-Matos, M., Cartamil, M., Zavala, C., and Rein, K. S. (2017). Toxin composition of the 2016 Microcystis aeruginosa bloom in the St. Lucie Estuary, Florida. Toxicon 138, 169-172. doi: 10.1016/j.toxicon.2017. 09.005
Office of Economic and Demographic Research (2021). Demographic Estimating Conference Executive Summary- Florida Demographic Forecast. Tallahassee, FL: Office of Economic and Demographic Research.

Okazaki, R. R., Towle, E. K., van Hooidonk, R., Mor, C., Winter, R. N., Piggot, A. M., et al. (2017). Species-specific responses to climate change and community composition determine future calcification rates of Florida Keys reefs. Glob. Change Biol. 23, 1023-1035. doi: 10.1111/gcb.13481

Osborne, N. J., Webb, P. M., and Shaw, G. R. (2001). The toxins of Lyngbya majuscula and their human and ecological health effects. Environ. Int. 27, 381-392. doi: 10.1016/S0160-4120(01)00098-8

Paerl, H. W., and Huisman, J. (2008). Blooms like it hot. Science 320, 57-58. doi: $10.1126 /$ science. 1155398

Paerl, H. W., and Paul, V. J. (2012). Climate change: links to global expansion of harmful cyanobacteria. Water Res. 46, 1349-1363. doi: 10.1016/j.watres.2011. 08.002

Paerl, H. W., Hall, N. S., and Calandrino, E. S. (2011). Controlling harmful cyanobacterial blooms in a world experiencing anthropogenic and climaticinduced change. Sci. Total Environ. 409, 1739-1745. doi: 10.1016/j.scitotenv. 2011.02.001

Paerl, H. W., Joyner, J. J., Joyner, A. R., Arthur, K., Paul, V., O'Neil, J. M., et al. (2008). Co-occurrence of dinoflagellate and cyanobacterial harmful algal blooms in southwest Florida coastal waters: dual nutrient ( $\mathrm{N}$ and $\mathrm{P}$ ) input controls. Mar. Ecol. Prog. Ser. 371, 143-153. doi: 10.3354/meps07681

Palafox, N., and Buenconsejo-Lum, L. (2001). Ciguatera fish poisoning: review of clinical manifestations. J. Toxicol. Toxin Rev. 20, 141-160. doi: 10.1081/TXR100105733

Parsons, M. L., Aligizaki, K., Bottein, M.-Y. D., Fraga, S., Morton, S. L., Penna, A., et al. (2012). Gambierdiscus and Ostreopsis: reassessment of the state of knowledge of their taxonomy, geography, ecophysiology, and toxicology. Harmful Algae 14, 107-129. doi: 10.1016/j.hal.2011.10.017

Parsons, M. L., and Dortch, Q. (2002). Sedimentological evidence of an increase in Pseudo-nitzschia (Bacillariophyceae) abundance in response to coastal eutrophication. Limnol. Oceanogr. 47, 551-558. doi: 10.4319/lo.2002.47.2.0551

Patel, S. S., Lovko, V. J., and Lockey, R. F. (2020). Red Tide: overview and clinical manifestations. J. Allergy Clin. Immunol. 8, 1219-1223. doi: 10.1016/j.jaip.2019. 10.030

Patz, J. A., Olson, S. H., and Gray, A. L. (2006). Climate change, oceans, and human health. Oceanography 19, 52-61.

Paul, J. H., Houchin, L., Griffin, D., Slifko, T., Guo, M., Richardson, B., et al. (2002). A filterable lytic agent obtained from a red tide bloom that caused lysis of Karenia brevis (Gymnodinum breve) cultures. Aquat. Microb. Ecol. 27, 21-27.

Paul, V. J., Thacker, R. W., Banks, K., and Golubic, S. (2005). Benthic cyanobacterial bloom impacts the reefs of South Florida (Broward County, USA). Coral Reefs 24, 693-697. doi: 10.1007/s00338-005-0061-x

Pauly, D. (1995). Anecdotes and the shifting baseline syndrome of fisheries. Trends Ecol. Evol. 10:430.

Peterson, B. J., Chester, C. M., Jochem, F. J., and Fourqurean, J. W. (2006). Potential role of sponge communities in controlling phytoplankton blooms in Florida Bay. Mar. Ecol. Prog. Ser. 328, 93-103. doi: 10.3354/meps328093

Phillips, C., and Brady, W. H. (1953). Sea Pests, Poisonous or Harmful Sea Life of Florida and the West Indies. Coral Gables, FL: University of Miami.

Phlips, E. J., Badylak, S., and Lynch, T. C. (1999). Blooms of the picoplanktonic cyanobacterium Synechococcus in Florida Bay, a subtropical inner-shelf lagoon. Limnol. Oceanogr. 44, 1166-1175. doi: 10.4319/lo.1999.44.4.1166

Phlips, E. J., Badylak, S., Christman, M., Wolny, J., Brame, J., Garland, J., et al. (2011). Scales of temporal and spatial variability in the distribution of harmful algae species in the Indian River Lagoon, Florida, USA. Harmful Algae 10, 277-290. doi: 10.1016/j.hal.2010.11.001

Phlips, E. J., Badylak, S., Lasi, M. A., Chamberlain, R., Green, W. C., Hall, L. M., et al. (2015). From red tides to green and brown tides: bloom dynamics in a restricted subtropical lagoon under shifting climatic conditions. Estuaries Coasts 38, 886-904.

Phlips, E. J., Badylak, S., Nelson, N. G., and Havens, K. E. (2020). Hurricanes, El Niño and harmful algal blooms in two sub-tropical Florida estuaries: direct and indirect impacts. Sci. Rep. 10:1910.

Phlips, E. J., Badylak, S., Youn, S., and Kelley, K. (2004). The occurrence of potentially toxic dinoflagellates and diatoms in a subtropical lagoon, the Indian 
River Lagoon, Florida, USA. Harmful Algae 3, 39-49. doi: 10.1016/j.hal.2003.08. 003

Phlips, E. J., Ihnat, J., and Conroy, M. (1992). Nitrogen fixation by the benthic freshwater cyanobacterium Lyngbya wollei. Hydrobiologia 234, 59-64.

Phlips, E., Badylak, S., Bledsoe, E., and Cichra, M. (2006). Factors affecting the distribution of Pyrodinium bahamense var. bahamense in coastal waters of Florida. Mar. Ecol. Prog. Ser. 322, 99-115. doi: 10.3354/meps322099

Pierce, R. H., Henry, M. S., Blum, P. C., Hamel, S. L., Kirkpatrick, B., Cheng, Y. S., et al. (2005). Brevetoxin composition in water and marine aerosol along a Florida beach: assessing potential human exposure to marine biotoxins. Harmful Algae 4, 965-972. doi: 10.1016/j.hal.2004.11.004

Pierce, R. H., Henry, M. S., Blum, P. C., Lyons, J., Cheng, Y. S., Yazzie, D., et al. (2003). Brevetoxin concentrations in marine aerosol: human exposure levels during a Karenia brevis harmful algal bloom. Bull. Environ. Contam. Toxicol. 70, 161-165.

Pierce, R. H., Henry, M. S., Higham, C. J., Blum, P., Sengco, M. R., and Anderson, D. M. (2004). Removal of harmful algal cells (Karenia brevis) and toxins from seawater culture by clay flocculation. Harmful Algae 3, 141-148. doi: 10.1016/j. hal.2003.09.003

Plaas, H. E., and Paerl, H. W. (2020). Toxic cyanobacteria: a growing threat to water and air quality. Environ. Sci. Technol. 55, 44-64. doi: 10.1021/acs.est.0c06653

Poli, M. (1982). A Review of Ciguatera, with Special Reference to the Caribbean, and an Investigation into its Significance and Incidence in Florida. Master's thesis. Coral Gables, FL: University of Miami.

Pörtner, H.-O., Roberts, D. C., Masson-Delmotte, V., Zhai, P., Tignor, M., Poloczanska, E., et al. (2019). IPCC Special Report on the Ocean and Cryosphere in a Changing climate. IPCC Intergovernmental Panel on Climate Change (IPCC). Geneva: IPCC

Pottier, I., Vernoux, J. P., and Lewis, R. J. (2001). "Ciguatera fish poisoning in the Caribbean islands and Western Atlantic," in Reviews of Environmental Contamination and Toxicology, eds G. W. Ware and H. N. Nigg (Tuscon, AZ: Springer), 99-141. doi: 10.1007/978-1-4613-0143-1_3

Poulin, R. X., Hogan, S., Poulson-Ellestad, K. L., Brown, E., Fernández, F. M., and Kubanek, J. (2018). Karenia brevis allelopathy compromises the lipidome, membrane integrity, and photosynthesis of competitors. Sci. Rep. 8:9572. doi: 10.1038/s41598-018-27845-9

Poulson-Ellestad, K., Mcmillan, E., Montoya, J. P., and Kubanek, J. (2014). Are offshore phytoplankton susceptible to Karenia brevis allelopathy? J. Plankton Res. 36, 1344-1356. doi: 10.1093/plankt/fbu064

Preece, E. P., Hardy, F. J., Moore, B. C., and Bryan, M. (2017). A review of microcystin detections in estuarine and marine waters: environmental implications and human health risk. Harmful Algae 61, 31-45. doi: 10.1016/j. hal.2016.11.006

Prince, E. K., Myers, T. L., and Kubanek, J. (2008). Effects of harmful algal blooms on competitors: allelopathic mechanisms of the red tide dinoflagellate Karenia brevis. Limnol. Oceanogr. 53, 531-541. doi: 10.4319/lo.2008.53.2.0531

Prince, E. K., Poulson, K. L., Myers, T. L., Sieg, R. D., and Kubanek, J. (2010). Characterization of allelopathic compounds from the red tide dinoflagellate Karenia brevis. Harmful Algae 10, 39-48. doi: 10.1016/j.hal.2010.06.003

Procise, L. A. (2012). Grazing on Synechococcus spp. by the Red-Tide Dinoflagellate Karenia brevis: Implications for Bloom Dynamics in the Gulf of Mexico. Ph.D. dissertation. Norfolk, VA: Old Dominion University. doi: 10.25777/jy09-7349

Pulido, O. M. (2008). Domoic acid toxicologic pathology: a review. Mar. Drugs 6, 180-219. doi: 10.3390/md6020180

Quijano-Scheggia, S., Olivos-Ortíz, A., Gaviño-Rodríguez, J. H., Castro-Ochoa, F., Rivera-Vilarelle, M., Galicia-Pérez, M., et al. (2011). First report of Pseudonitzschia brasiliana and P. micropora (Bacillariophyceae) found in Cuyutlan Lagoon, Mexico. Rev. Biol. Mar. Oceanogr. 46, 189-197.

Quilliam, M., Wechsler, D., Marcus, S., Ruck, B., Wekell, M., and Hawryluk, T. (2002). "Detection and identification of paralytic shellfish poisoning toxins in Florida pufferfish responsible for incidents of neurologic illness," in Harmful Algae 2002, eds K. A. Steidinger, J. H. Landsberg, C. R. Tomas, G. A. Vargo (St. Petersburg, FL: Florida Fish and Wildlife Conservation Commission), 116-118.

Quod, J. P., and Turquet, J. (1996). Ciguatera in Reunion Island (SW Indian Ocean): epidemiology and clinical patterns. Toxicon 34, 779-785. doi: 10.1016/ 0041-0101(95)00164-6

Radke, E. G., Reich, A., and Morris, J. G. Jr. (2015). Epidemiology of ciguatera in Florida. Am. J. Trop. Med. Hyg. 93, 425-432. doi: 10.4269/ajtmh.14-0400
Rains, L. K. (2015). Effects of Macroalgal Hosts on the Growth and Epiphytic Behavior of five Gambierdiscus Species from the Greater Caribbean Region. Ph.D. dissertation. Fort Myers, FL: Florida Gulf Coast University.

Raizin, M., and Meaburn, M. (1988). "Avoidance costs due to public awareness of ciguatera fish poisonings in Florida and Hawaii," in Proceedings of the 12th Annual Conference Tropical and Subtropical Fisheries Society of America SGR-92. Florida Sea Grant College Program, Gainesville, FL, 567-582.

Ramani, A., Rein, K., Shetty, K., and Jayachandran, K. (2012). Microbial degradation of microcystin in Florida's freshwaters. Biodegradation 23, 35-45. doi: 10.1007/s10532-011-9484-y

Reece, J. S., Noss, R. F., Oetting, J., Hoctor, T., and Volk, M. (2013). A vulnerability assessment of 300 species in Florida: threats from sea level rise, land use, and climate change. PLoS One 8:e80658. doi: 10.1371/journal.pone.0080658

Reichwaldt, E. S., and Ghadouani, A. (2012). Effects of rainfall patterns on toxic cyanobacterial blooms in a changing climate: between simplistic scenarios and complex dynamics. Water Res. 46, 1372-1393. doi: 10.1016/j.watres.2011.11. 052

ReVelle, P., and ReVelle, C. (1988). The Environment: Issues and Choices for Society, 3rd Edn. (Boston, MA: Jones and Bartlett Publishers), 749.

Richardson, L. L., and Zimba, P. V. (2002). "Spatial and temporal patterns of phytoplankton in Florida Bay: utility of algal accessory pigments and remote sensing to assess bloom dynamics," in The Everglades, Florida Bay and Coral Reefs of the Florida Keys, An Ecosystem Sourcebook, eds J. W. Porter and K. G. Porter (Boca Raton, FL: CRC Press), 461-478.

Riedinger-Whitmore, M. A., Whitmore, T. J., Smoak, J. M., Brenner, M., Moore, A., Curtis, J., et al. (2005). Cyanobacterial proliferation is a recent response to eutrophication in many Florida lakes: a paleolimnological assessment. Lake Reserv. Manage. 21, 423-435. doi: 10.1080/07438140509354447

Robblee, M. B., Barber, T., Carlson, Jr., Durako, M., Fourqurean, J. W., Muehlstein, L., et al. (1991). Mass mortality of the tropical seagrass Thalassia testudinum in Florida Bay (USA). Mar. Ecol. Prog. Ser. 71, 297-299.

Rongo, T., and van Woesik, R. (2011). Ciguatera poisoning in Rarotonga, southern Cook islands. Harmful Algae 10, 345-355. doi: 10.1016/j.hal.2010.11.005

Rongo, T., and van Woesik, R. (2013). The effects of natural disturbances, reef state, and herbivorous fish densities on ciguatera poisoning in Rarotonga, southern Cook Islands. Toxicon 64, 87-95. doi: 10.1016/j.toxicon.2012.12.018

Roth, P. B., Twiner, M. J., Mikulski, C. M., Barnhorst, A. B., and Doucette, G. J. (2008). Comparative analysis of two algicidal bacteria active against the red tide dinoflagellate Karenia brevis. Harmful Algae 7, 682-691. doi: 10.1016/j.hal.2008. 02.002

Roth, P. B., Twiner, M. J., Wang, Z., Dechraoui, M.-Y. B., and Doucette, G. J. (2007). Fate and distribution of brevetoxin $(\mathrm{PbTx})$ following lysis of Karenia brevis by algicidal bacteria, including analysis of open A-ring derivatives. Toxicon 50 , 1175-1191. doi: 10.1016/j.toxicon.2007.08.003

Round, F. E., and Crawford, R. M. (1984). The lines of evolution of the Bacillariophyta. II. The centric series. Proc. R. Soc. Lond. Ser. B Biol. Sci. 221, 169-188.

Saeed, A. F., Awan, S. A., Ling, S., Wang, R., and Wang, S. (2017). Domoic acid: attributes, exposure risks, innovative detection techniques and therapeutics. Algal Res. 24, 97-110. doi: 10.1016/j.algal.2017.02.007

Sarasota Herald Tribune (1947). Sarasota Herald Tribune Newspaper Archives August 28, 1947 Page 12. Available online at: https://newspaperarchive. com/sarasota-herald-tribune-aug-28-1947-p-12/ (accessed December 1, 2020).

Saunders, R. P., and Glenn, D. A. (1969). "Diatoms,".Memories of the Hourglass Cruises Vol. 1. Pt. 3. Contribution No. 127. (St. Petersburg, FL: Florida Department of Natural Resources), 1-19.

Schaefer, A. M., Yrastorza, L., Stockley, N., Harvey, K., Harris, N., Grady, R., et al. (2020). Exposure to microcystin among coastal residents during a cyanobacteria bloom in Florida. Harmful Algae 92:101769. doi: 10.1016/j.hal.2020.10 1769

Scholin, C. A., Gulland, F., Doucette, G. J., Benson, S., Busman, M., Chavez, F. P., et al. (2000). Mortality of sea lions along the central California coast linked to a toxic diatom bloom. Nature 403, 80-84. doi: 10.1038/47481

Schwacke, L. H., Twiner, M. J., De Guise, S., Balmer, B. C., Wells, R. S., Townsend, F. I., et al. (2010). Eosinophilia and biotoxin exposure in bottlenose dolphins (Tursiops truncatus) from a coastal area impacted by repeated mortality events. Environ. Res. 110, 548-555. doi: 10.1016/j.envres.2010.05.003 
Sengco, M. (2009a). "Mitigation of effects of harmful algal blooms," in Shellfish Safety and Quality, eds S. Shumway and G. Rodrick (Amsterdam: Elsevier), 175-199. doi: 10.1533/9781845695576.2.175

Sengco, M. R. (2009b). Prevention and control of Karenia brevis blooms. Harmful Algae 8, 623-628. doi: 10.1016/j.hal.2008.11.005

Sengco, M. R., Li, A., Tugend, K., Kulis, D., and Anderson, D. M. (2001). Removal of red-and brown-tide cells using clay flocculation. I. Laboratory culture experiments with Gymnodinium breve and Aureococcus anophagefferens. Mar. Ecol. Prog. Ser. 210, 41-53. doi: 10.3354/meps210041

Shanley, E. (1985). Photoadaptation in the Red-Tide Dinoflagellate Ptychodiscus brevis. Master's thesis. Tampa, FL: University of South Florida. 122.

Shanley, E., and Vargo, G. A. (1993). "Cellular composition, growth, photosynthesis, and respiration rates of Gymnodinium breve under varying light levels," in Toxic Phytoplankton Blooms in the Sea, eds T. J. Smayda and Y. Shimizu (Amsterdam: Elsevier), 831-836.

Shannon, E. E., and Brezonik, P. L. (1972). Limnological characteristics of north and central florida lakes. Limnol. Oceanogr. 17, 97-110. doi: 10.4319/lo.1972. 17.1.0097

Sharp, K., Arthur, K. E., Gu, L., Ross, C., Harrison, G., Gunasekera, S. P., et al. (2009). Phylogenetic and chemical diversity of three chemotypes of bloom-forming Lyngbya species (Cyanobacteria: Oscillatoriales) from reefs of southeastern Florida. Appl. Environ. Microbiol. 75, 2879-2888. doi: 10.1128/ AEM.02656-08

Shimizu, Y. (2003). Microalgal metabolites. Curr. Opin. Microbiol. 6, 236-243. doi: 10.1016/S1369-5274(03)00064-X

Shumway, S. E. (2011). Shellfish Aquaculture and the Environment. Hoboken, NJ: John Wiley \& Sons.

Shumway, S. E., Burkholder, J. M., and Morton, S. L. (2018). Harmful Algal Blooms: A Compendium Desk Reference. (Hoboken, NJ: John Wiley \& Sons), 696.

Sierra Beltrán, A., Palafox-Uribe, M., Grajales-Montiel, J., Cruz-Villacorta, A., and Ochoa, J. (1997). Sea bird mortality at Cabo San Lucas, Mexico: evidence that toxic diatom blooms are spreading. Toxicon 35, 447-453. doi: 10.1016/S00410101(96)00140-7

Sims, J. K. (1987). A theoretical discourse on the pharmacology of toxic marine ingestions. Ann. Emerg. Med. 16, 1006-1015. doi: 10.1016/s0196-0644(87) 80750-3

Sinclair, G. A., and Kamykowski, D. (2008). Benthic-pelagic coupling in sedimentassociated populations of Karenia brevis. J. Plankton Res. 30, 829-838. doi: 10.1093/plankt/fbn042

Singh, I. P., Milligan, K. E., and Gerwick, W. H. (1999). Tanikolide, a Toxic and Antifungal Lactone from the Marine Cyanobacterium Lyngbya majuscula. J. Nat. Prod. 62, 1333-1335.

Sipler, R. E., Bronk, D. A., Seitzinger, S. P., Lauck, R. J., McGuinness, L. R., Kirkpatrick, G. J., et al. (2013). Trichodesmium-derived dissolved organic matter is a source of nitrogen capable of supporting the growth of toxic red tide Karenia brevis. Mar. Ecol. Prog. Ser. 483, 31-45. doi: 10.3354/meps10258

Skinner, M. P., Brewer, T. D., Johnstone, R., Fleming, L. E., and Lewis, R. J. (2011). Ciguatera fish poisoning in the Pacific Islands (1998 to 2008). PLoS Negl. Trop. Dis. 5:e1416. doi: 10.1371/journal.pntd.0001416

Slobodkin, L. B. (1953). A possible initial condition for red tides on the coast of Florida. J. Mar. Res. 12, 148-155.

Slomp, C. P., and Van Cappellen, P. (2004). Nutrient inputs to the coastal ocean through submarine groundwater discharge: controls and potential impact. J. Hydrol. 295, 64-86. doi: 10.1016/j.jhydrol.2004.02.018

Smayda, T. J. (1989). "Primary production and the global epidemic of phytoplankton blooms in the sea: A linkage?" in Novel Phytoplankton Blooms, eds E. M. Cosper, V. M. Bricelj, E. J. Carpenter (Berlin: Springer), 449-483.

Smayda, T. J. (1990). "Novel and nuisance algal blooms in the sea: evidence for a global epidemic," in Toxic Marine Phytoplankton, eds E. Granéli, B. Sundström, L. Edler, and D. M. Anderson (New York, NY: Elsevier), 29-40.

Smayda, T. J. (1997). What is a bloom? A commentary. Limnol. Oceanogr. 42, 1132-1136. doi: 10.4319/lo.1997.42.5_part_2.1132

Smayda, T. J. (2007). Reflections on the ballast water dispersal-harmful algal bloom paradigm. Harmful Algae 6, 601-622. doi: 10.1016/j.hal.2007. 02.003

Smetacek, V., and Zingone, A. (2013). Green and golden seaweed tides on the rise. Nature 504, 84-88.
Smith, G. B. (1975). The 1971 red tide and its impact on certain reef communities in the eastern Gulf of Mexico. Environ. Lett. 9, 141-152. doi: 10.1080/ 00139307509435843

Smith, G. B. (1979). Relationship of eastern Gulf of Mexico reef fish communities to the species equilibrium theory of insular biogeography. J. Biogeogr. 6, 49-61. doi: $10.2307 / 3038151$

Smith, N. P. (1993). Tidal and nontidal flushing of Florida’s Indian River Lagoon. Estuaries 16, 739-746. doi: 10.2307/1352432

Snedaker, S. C. (1995). Mangroves and climate change in the Florida and Caribbean region: scenarios and hypotheses. Hydrobiologia 295, 43-49.

Soga, M., and Gaston, K. J. (2018). Shifting baseline syndrome: causes, consequences, and implications. Front. Ecol. Environ. 16, 222-230. doi: 10.1002/ fee. 1794

Soliño, L., and Costa, P. R. (2020). Global impact of ciguatoxins and ciguatera fish poisoning on fish, fisheries and consumers. Environ. Res. 182:109111. doi: 10.1016/j.envres.2020.109111

Søndergaard, M., Jensen, J. P., and Jeppesen, E. (2003). Role of sediment and internal loading of phosphorus in shallow lakes. Hydrobiologia 506, 135-145.

Sournia, A. (1995). "Red tide and toxic marine phytoplankton of the world ocean: an inquiry into biodiversity," in Harmful Marine Algal Blooms. Proceedings of the sixth International Conference on Toxic Marine Phytoplankton (Paris: Lavoisier Publishing), 103-112.

Sournia, A., Chrdtiennot-Dinet, M.-J., and Ricard, M. (1991). Marine phytoplankton: how many species in the world ocean? J. Plankton Res. 13, 1093-1099. doi: 10.1093/plankt/13.5.1093

Spáèil, Z., Eriksson, J., Jonasson, S., Rasmussen, U., Ilag, L. L., and Bergman, B. (2010). Analytical protocol for identification of BMAA and DAB in biological samples. Analyst 135, 127-132. doi: 10.1039/B921048B

Steidinger, K. A. (1973). Phytoplankton ecology: a conceptual review based on eastern Gulf of Mexico research. CRC Crit. Rev. Microbiol. 3, 49-68. doi: 10. 3109/10408417309108745

Steidinger, K. A. (1975). "Basic factors influencing red tides," in Proceedings of the 1st International Conference on Toxic Dinoflagellate Blooms, ed. V. R. LoCicero (Boston, MA: Massachusetts Science and Technology Foundation), 153-162.

Steidinger, K. A. (2009). Historical perspective on Karenia brevis red tide research in the Gulf of Mexico. Harmful Algae 8, 549-561. doi: 10.1016/j.hal.2008.11.009

Steidinger, K. A., Meave, and del Castillo, M. E. (2018). Guide to the Identification of Harmful Microalgae in the Gulf of Mexico, Volume I: Taxonomy. St. Petersburg, FL: DiggyPOD, Inc.

Steidinger, K., Tester, L., and Taylor, F. J. R. (1980). A redescription of Pyrodinium bahamense var. compressa (Böhm) stat. nov. from Pacific red tides. Phycologia 19, 329-334. doi: 10.2216/i0031-8884-19-4-329.1

Steinman, A., Havens, K., and Hornung, L. (2002). The managed recession of Lake Okeechobee, Florida: integrating science and natural resource management. Conserv. Ecol. 6:17. doi: 10.5751/ES-00417-060217

Stevely, J. M., Sweat, D. E., Bert, T. M., Sim-Smith, C., and Kelly, M. (2010). Sponge Mortality at Marathon and Long Key, Florida: patterns of Species Response and Population Recovery. Proc. Gulf Caribb. Fish. Inst. 63, 384-400.

Stevenson, R. J., Pinowska, A., Albertin, A., and Sickman, J. (2007). Ecological Condition of Algae and Nutrients in Florida Springs: The Synthesis Report. Environmental Assessment Section. (Tallahassee, FL: Florida Department of Environmental Protection), 1-58.

Stewart, I., Webb, P. M., Schluter, P. J., and Shaw, G. R. (2006a). Recreational and occupational field exposure to freshwater cyanobacteria-a review of anecdotal and case reports, epidemiological studies and the challenges for epidemiologic assessment. Environ. Health 5:6. doi: 10.1186/1476-069X-5-6

Stewart, I., Webb, P. M., Schluter, P. J., Fleming, L. E., Burns, J. W., Gantar, M., et al. (2006b). Epidemiology of recreational exposure to freshwater cyanobacteria-an international prospective cohort study. BMC Public Health 6:93. doi: 10.1186/ 1471-2458-6-93

Stumpf, R. P. (2008). "Developing operational capabilities for nowcasts and forecasts of harmful algal blooms," in Proceedings XII International Conference on Harmful Algae, IOC of UNESCO, Copenhagen, 96-98.

Stumpf, R. P., Tomlinson, M. C., Calkins, J. A., Kirkpatrick, B., Fisher, K., Nierenberg, K., et al. (2009). Skill assessment for an operational algal bloom forecast system. J. Mar. Syst. 76, 151-161. doi: 10.1016/j.jmarsys.2008.05.016

Stumpf, R., Culver, M., Tester, P., Tomlinson, M., Kirkpatrick, G., Pederson, B., et al. (2003). Monitoring Karenia brevis blooms in the Gulf of Mexico using 
satellite ocean color imagery and other data. Harmful Algae 2, 147-160. doi: 10.1016/S1568-9883(02)00083-5

Stumpf, R., Frayer, M., Durako, M. J., and Brock, J. (1999). Variations in water clarity and bottom albedo in Florida Bay from 1985 to 1997. Estuaries 22, 431-444.

Subba Rao, D., Quilliam, Michael, and Pocklington, R. (1988). Domoic Acid-A neurotoxic amino acid produced by the marine diatom Nitzschia pungens in Culture. Can. J. Fish. Aquat. Sci. 45, 2076-2079. doi: 10.1139/f88-241

Sullivan, M. J. (1978). Diatom community structure: taxonomic and statistical analyses of a salt marsh. J. Phycol. 14, 468-475. doi: 10.1111/j.1529-8817.1978. tb02471.x

Sun, J., Hutchins, D. A., Feng, Y., Seubert, E. L., Caron, D. A., and Fu, F.X. (2011). Effects of changing $\mathrm{pCO}_{2}$ and phosphate availability on domoic acid production and physiology of the marine harmful bloom diatom Pseudonitzschia multiseries. Limnol. Oceanogr. 56, 829-840. doi: 10.4319/lo.2011.56.3. 0829

Sunda, W. G., Graneli, E., and Gobler, C. J. (2006). Positive feedback and the development and persistence of ecosystem disruptive algal blooms 1. J. Phycol. 42, 963-974. doi: 10.1111/j.1529-8817.2006.00261.x

Sunesen, I., Bárcena, A., and Sar, E. A. (2009). Diatomeas potencialmente nocivas del Golfo San Matías (Argentina). Rev. Biol. Mar. Oceanogr. 44, 67-88. doi: 10.4067/S0718-19572009000100007

Sutherland, J. W., Turcotte, R. J., Molden, E., Moriarty, V., Kelly, M., Aubel, M., et al. (2021). The detection of airborne anatoxin-a (ATX) on glass fiber filters during a harmful algal bloom. Lake Reserv. Manage. [Epub ahead of print]. doi: 10.1080/10402381.2021.1881191

Tatters, A. O., Fu, F.-X., and Hutchins, D. A. (2012). High $\mathrm{CO}_{2}$ and silicate limitation synergistically increase the toxicity of Pseudo-nitzschia fraudulenta. PLoS One 7:e32116. doi: 10.1371/journal.pone.0032116

Tatters, A. O., Smith, J., Kudela, R. M., Hayashi, K., Howard, M. D., Donovan, A. R., et al. (2021). The tide turns: episodic and localized cross-contamination of a California coastline with cyanotoxins. Harmful Algae 103:102003. doi: 10.1016/j.hal.2021.102003

Taylor, F. (1979). "Description of the benthic dinoflagellate associated with maitotoxin and ciguatoxin, including observations on Hawaiian material," in Toxic Dinoflagellate Blooms, eds D. L. Taylor and H. H. Seliger (New York, NY: Elsevier), 71-76.

Taylor, F. J., and Pollingher, U. (1987). "Ecology of dinoflagellates," in The Biology of Dinoflagellates, ed. F. J. Taylor (Malden, MA: Blackwell Sci), 398-529.

Taylor, H. F. (1917). Mortality of Fishes on the West Coast of Florida. Report to the U.S. Commissioner of Fisheries. Washington DC: Government Printing Office.

Tester, P. (1993). "Gymnodinium breve and global warming: What are the possibilities?" in Toxic Phytoplankton Blooms in the Sea, eds T. J. Smayda and Y. Shimizu (Amsterdam: Elsevier), 67-72.

Tester, P. A., and Fowler, P. K. (1990). "Brevetoxin contamination of Mercenaria mercenaria and Crassostrea virginica: a management issue," in Proceedings of the 4th International Conference: Toxic Marine Phytoplankton, eds E. Graneli, B. Sundström, L. Edler, and D. M. Anderson (New York, NY: Academic Press), 499-503.

Tester, P. A., and Steidinger, K. A. (1997). Gymnodinium breve red tide blooms: initiation, transport, and consequences of surface circulation. Limnol. Oceanogr. 42, 1039-1051. doi: 10.4319/lo.1997.42.5_part_ 2.1039

Tester, P. A., Feldman, R. L., Nau, A. W., Kibler, S. R., and Litaker, R. W. (2010). Ciguatera fish poisoning and sea surface temperatures in the Caribbean Sea and the West Indies. Toxicon 56, 698-710. doi: 10.1016/j.toxicon.2010.02.026

Tester, P. A., Stumpf, R. P., Vukovich, F. M., Fowler, P. K., and Turner, J. T. (1991). An expatriate red tide bloom: transport, distribution, and persistence. Limnol. Oceanogr. 36, 1053-1061. doi: 10.4319/lo.1991.36.5.1053

Tett, P., and Barton, E. (1995). Why are there about 5000 species of phytoplankton in the sea? J. Plankton Res. 17, 1693-1704. doi: 10.1093/plankt/17.8.1693

The Balmoral Group. (2020). Economic Impacts of Water Quality Issues in the Gulf of Mexico. Final Report to the Gulf of Mexico Alliance. Winter Park, FL: The Balmoral Group.

Thessen, A. E., Bowers, H. A., and Stoecker, D. K. (2009). Intra-and interspecies differences in growth and toxicity of Pseudo-nitzschia while using different nitrogen sources. Harmful Algae 8, 792-810. doi: 10.1016/j.hal.2009. 01.003
Thorhaug, A., and Roessler, M. (1977). Seagrass community dynamics in a subtropical estuarine lagoon. Aquaculture 12, 253-277. doi: 10.1016/00448486(77)90066-7

Tiling, K., and Proffitt, C. E. (2017). Effects of Lyngbya majuscula blooms on the seagrass Halodule wrightii and resident invertebrates. Harmful Algae 62, 104-112. doi: 10.1016/j.hal.2016.11.015

Tindall, D. R., Dickey, R. W., Carlson, R. D., and Morey-Gaines, G. (1984). "Ciguatoxigenic dinoflagellates from the Caribbean Sea," in Seafood Toxins, ed. E. P. Ragelis (Washington, DC: ACS Publications). doi: 10.1021/bk-1984-0262. ch021

Tindall, D. R., Miller, D. M., and Tindall, P. T. (1990). "Toxicity of Ostreopsis lenticularis from the British and United States Virgin Islands," in Toxic Marine Phytoplankton, eds E. Graneli, et al. (New York, NY: Elsevier), 424-429.

Tobey, J., Rubinoff, P., Robadue, D. Jr., Ricci, G., Volk, R., Furlow, J., et al. (2010). Practicing coastal adaptation to climate change: lessons from integrated coastal management. Coast. Manage. 38, 317-335. doi: 10.1080/08920753.2010.483169

Todd, E. C. (1993). Domoic acid and amnesic shellfish poisoning-a review. J. Food Prot. 56, 69-83. doi: 10.4315/0362-028X-56.1.69

Todd, E. C. D. (1985). "Ciguatera poisoning in Canada," in Toxic Dinoflagellates. Proceedings of the Third International Conference, eds D. M. Anderson, A. W. White, and D. G. Baden (North Holland, NY: Elsevier), 505-510.

Townhill, B. L., Tinker, J., Jones, M., Pitois, S., Creach, V., Simpson, S. D., et al. (2018). Harmful algal blooms and climate change: exploring future distribution changes. ICES J. Mar. Sci. 75, 1882-1893. doi: 10.1093/icesjms/fsy113

Trainer, V. L., Bates, S. S., Lundholm, N., Thessen, A. E., Cochlan, W. P., Adams, N. G., et al. (2012). Pseudo-nitzschia physiological ecology, phylogeny, toxicity, monitoring and impacts on ecosystem health. Harmful Algae 14, 271-300. doi: 10.1016/j.hal.2011.10.025

Trimborn, S., Lundholm, N., Thoms, S., Richter, K. U., Krock, B., Hansen, P. J., et al. (2008). Inorganic carbon acquisition in potentially toxic and non-toxic diatoms: the effect of $\mathrm{pH}$-induced changes in seawater carbonate chemistry. Physiol. Plant. 133, 92-105. doi: 10.1111/j.1399-3054.2007.01038.x

Turner, A. D., Higgins, C., Davidson, K., Veszelovszki, A., Payne, D., Hungerford, J., et al. (2015). Potential threats posed by new or emerging marine biotoxins in UK waters and examination of detection methodology used in their control: brevetoxins. Mar. Drugs 13, 1224-1254. doi: 10.3390/md13031224

Turner, J. T., and Tester, P. A. (1989). "Zooplankton feeding ecology: copepod grazing during an expatriate red tide," in Phytoplankton Blooms, eds E. M. Cosper, V. M. Bricelj, and E. J. Carpenter (Berlin: Springer-Verlag), 359-374.

Turner, J. T., and Tester, P. A. (1997). Toxic marine phytoplankton, zooplankton grazers, and pelagic food webs. Limnol. Oceanogr. 42, 1203-1214. doi: 10.4319/ lo.1997.42.5_part_2.1203

Turner, R., Rabalais, N., Fry, B., Atilla, N., Milan, C., Lee, J., et al. (2006). Paleoindicators and water quality change in the Charlotte Harbor Estuary (Florida). Limnol. Oceanogr. 51, 518-533. doi: 10.4319/lo.2006.51.1_part_2.0518

Twiner, M. J., Fire, S., Schwacke, L., Davidson, L., Wang, Z., Morton, S., et al. (2011). Concurrent exposure of bottlenose dolphins (Tursiops truncatus) to multiple algal toxins in Sarasota Bay, Florida, USA. PLoS One 6:e17394. doi: 10.1371/journal.pone.0017394

Uhlenbrock, K. M. (2009). Nutrient Distribution Effects from Freshwater Discharge at Franklin Lock and Dam (S-79) in 2005 and 2006 on the Caloosahatchee Estuary and San Carlos Bay. Master's thesis. Fort Myers, FL: University of South Florida.

United Nations Environment Programme, Joint Group of Experts on the Scientific Aspects of Marine Environmental Protection (2001). Protecting the Oceans from Land-Based Activities - Land-Based Sources and Activities Affecting the Quality and Uses of the Marine, Coastal and Associated Freshwater Environment. Rep. Stud. GESAMP No. 71, 162. London: International Maritime Organization [IMO].

United States Environmental Protection Agency (2015). 2015 Drinking Water Health Advisories for Two Cyanobacterial Toxins. Office of Water. Washington, DC: United States Environmental Protection Agency.

Urakawa, H., Hancock, T. L., Steele, J. H., Dahedl, E. K., Urakawa, H. E., Ndungu, L. K., et al. (2020). Complete Genome Sequence of Microcystis aeruginosa FD4, Isolated from a Subtropical River in Southwest Florida. Microbiol. Resour. Announc. 9:e00813-20. doi: 10.1128/MRA.00813-20

Urquhart, E. A., Schaeffer, B. A., Stumpf, R. P., Loftin, K. A., and Werdell, P. J. (2017). A method for examining temporal changes in cyanobacterial harmful 
algal bloom spatial extent using satellite remote sensing. Harmful Algae 67, 144-152. doi: 10.1016/j.hal.2017.06.001

Usup, G. (1996). The Physiology and Toxicity of the Red Tide Dinoflagellate Pyrodinium bahamense var. Compressum. Ph.D. thesis. Boston, MA: Boston University.

Usup, G., Ahmad, A., Matsuoka, K., Lim, P. T., and Leaw, C. P. (2012). Biology, ecology and bloom dynamics of the toxic marine dinoflagellate Pyrodinium bahamense. Harmful Algae 14, 301-312. doi: 10.1016/j.hal.2011.10.026

Valiela, I., McClelland, J., Hauxwell, J., Behr, P. J., Hersh, D., and Foreman, K. (1997). Macroalgal blooms in shallow estuaries: controls and ecophysiological and ecosystem consequences. Limnol. Oceanogr. 42, 1105-1118. doi: 10.4319/ lo.1997.42.5_part_2.1105

Van Deventer, M., Atwood, K., Vargo, G. A., Flewelling, L. J., Landsberg, J. H., Naar, J. P., et al. (2012). Karenia brevis red tides and brevetoxin-contaminated fish: a high risk factor for Florida’s scavenging shorebirds? Bot. Mar. 55, 31-37. doi: 10.1515/bot.2011.122

Van Dolah, F. M. (2000). Marine algal toxins: origins, health effects, and their increased occurrence. Environ. Health Perspect. 108(Suppl. 1), 133-141.

Van Dolah, F. M., Roelke, D., and Greene, R. M. (2001). Health and ecological impacts of harmful algal blooms: risk assessment needs. Hum. Ecol. Risk Assess. 7, 1329-1345. doi: 10.1080/20018091095032

van Tussenbroek, B. I. (2011). Dynamics of seagrasses and associated algae in coral reef lagoons. Hidrobiológica 21, 293-310.

Vargo, G. A. (2009). A brief summary of the physiology and ecology of Karenia brevis Davis (G. Hansen and Moestrup comb. nov.) red tides on the West Florida Shelf and of hypotheses posed for their initiation, growth, maintenance, and termination. Harmful Algae 8, 573-584. doi: 10.1016/j.hal.2008.11.002

Vargo, G. A., Heil, C. A., Ault, D. N., Neely, M. B., Murasko, S., Havens, J., et al. (2004). "Four Karenia brevis blooms: a comparative analysis," in Harmful Algae 2002, eds K. A. Steidinger, J. H. Landsberg, C. R. Tomas, and G. A. Vargo (St. Petersburg, FL: Florida Fish and Wildlife Conservation Commission), 14-16.

Vargo, G. A., Heil, C. A., Fanning, K. A., Dixon, L. K., Neely, M. B., Lester, K., et al. (2008). Nutrient availability in support of Karenia brevis blooms on the central West Florida Shelf: What keeps Karenia blooming? Cont. Shelf Res. 28, 73-98. doi: 10.1016/j.csr.2007.04.008

Vargo, G. C., Heil, D., Spence, M., Neely, R., Merkt, K., Lester, R., et al. (2001). “The hydrographic regime, nutrient requirements, and transport of a Gymnodinium breve Davis red tide on the west Florida shelf," in Harmful Algal Blooms, Proceedings of the Ninth International Conference on Harmful Algae, eds G. Hallegraeff, S. I. Blackburn, C. J. Bolch, and R. J. Lewis (Hobart: IOC), $157-160$

Villareal, T. A., Chirichella, T., and Buskey, E. J. (2004). "Regional distribution of the Texas brown tide (Aureoumbra lagunensis) in the Gulf of Mexico," in Harmful algae 2002, eds K. A. Steidinger, J. H. Landsberg, C. R. Tomas, and G. A. Vargo (New York, NY: Florida Fish and Wildlife Conservation Commission), 374-376.

Villareal, T., Hanson, S., Qualia, S., Jester, E., Granade, H., and Dickey, R. (2007). Petroleum production platforms as sites for the expansion of ciguatera in the northwestern Gulf of Mexico. Harmful Algae 6, 253-259. doi: 10.1016/j.hal. 2006.08.008

Violi, J. P., Facey, J. A., Mitrovic, S. M., Colville, A., and Rodgers, K. J. (2019). Production of $\beta$-methylamino-L-alanine (BMAA) and Its Isomers by Freshwater Diatoms. Toxins 11:512. doi: 10.3390/toxins11090512

Virnstein, R. W., and Carbonara, P. A. (1985). Seasonal abundance and distribution of drift algae and seagrasses in the mid-Indian River Lagoon, Florida. Aquat. Bot. 23, 67-82. doi: 10.1016/0304-3770(85)90021-X

Visit Sarasota County (2019). Economic Impact of Tourism Fiscal Year 2019. Sarasota, FL: Visit Sarasota County (VSC).

Waggett, R. J., Hardison, D. R., and Tester, P. A. (2012). Toxicity and nutritional inadequacy of Karenia brevis: synergistic mechanisms disrupt top-down grazer control. Mar. Ecol. Prog. Ser. 444, 15-30. doi: 10.3354/meps09401

Walsby, A. E., Hayes, P. K., Boje, R., and Stal, L. J. (1997). The selective advantage of buoyancy provided by gas vesicles for planktonic cyanobacteria in the Baltic Sea. New Phytol. 136, 407-417. doi: 10.1046/j.1469-8137.1997.00754.x

Walsh, B. M., and O'Neil, J. M. (2014). Zooplankton community composition and copepod grazing on the West Florida Shelf in relation to blooms of Karenia brevis. Harmful Algae 38, 63-72. doi: 10.1016/j.hal.2014. 04.011
Walsh, C. J., Cocilova, C., Restivo, J., Flewelling, L., and Milton, S. (2019). Immune function in Trachemys scripta following exposure to a predominant brevetoxin congener, $\mathrm{PbTx}-3$, as a model for potential health impacts for sea turtles naturally exposed to brevetoxins. Ecotoxicology 28, 1085-1104. doi: 10.1007/ s10646-019-02110-5

Walsh, J. J., and Steidinger, K. A. (2001). Saharan dust and Florida red tides: the cyanophyte connection. J. Geophys. Res. Oceans 106, 11597-11612. doi: 10.1029/1999JC000123

Walsh, J. J., Jolliff, J., Darrow, B., Lenes, J., Milroy, S., Remsen, A., et al. (2006). Red tides in the Gulf of Mexico: Where, when, and why? J. Geophys. Res. Oceans 111, 1-46. doi: 10.1029/2004JC002813

Walsh, J. J., Penta, B., Dieterle, D. A., and Bissett, W. P. (2001). Predictive ecological modeling of harmful algal blooms. Hum. Ecol. Risk Assess. 7, 1369-1383. doi: $10.1080 / 20018091095069$

Walsh, J. J., Weisberg, R. H., Lenes, J. M., Chen, F. R., Dieterle, D. A., Zheng, L., et al. (2009). Isotopic evidence for dead fish maintenance of Florida red tides, with implications for coastal fisheries over both source regions of the West Florida shelf and within downstream waters of the South Atlantic Bight. Prog. Oceanogr. 80, 51-73. doi: 10.1016/j.pocean.2008.12.005

Wang, M., Hu, C., Barnes, B. B., Mitchum, G., Lapointe, B., and Montoya, J. P. (2019). The great Atlantic Sargassum belt. Science 365, 83-87. doi: 10.1126/ science.aaw7912

Weisberg, L., Zheng, Y., Liu, C., Lembke, C., Lenes, J. M., and Walsh, J. J. (2014). Why no red tide was observed on the West Florida Continental Shelf in 2010. Harmful Algae 38, 119-126. doi: 10.1016/j.hal.2014.04.010

Weisberg, R. H., and He, R. (2003). Local and deep-ocean forcing contributions to anomalous water properties on the West Florida Shelf. J. Geophys. Res. 108:3184. doi: 10.1029/2002JC001407

Weisberg, R. H., Barth, A., Alvera-Azcárate, A., and Zheng, L. (2009). A coordinated coastal ocean observing and modeling system for the West Florida Shelf. Harmful Algae 8, 585-598. doi: 10.1016/j.hal.2008.11.003

Weisberg, R. H., Liu, Y., Lembke, C., Hu, C., Hubbard, K., and Garrett, M. (2019). The coastal ocean circulation influence on the 2018 West Florida Shelf K. brevis red tide bloom. J. Geophys. Res. Oceans 124, 2501-2512. doi: 10.1029/ 2018JC014887

Weisberg, R. H., Zheng, L., Liu, Y., Corcoran, A., Lembke, C., Hu, C., et al. (2016). Karenia brevis blooms on the west Florida shelf: a comparative study of the robust 2012 bloom and the nearly null 2013 event. Cont. Shelf Res. 120, 106-121. doi: 10.1016/j.csr.2016.03.011

Wells, M. L., Trainer, V. L., Smayda, T. J., Karlson, B. S., Trick, C. G., Kudela, R. M., et al. (2015). Harmful algal blooms and climate change: learning from the past and present to forecast the future. Harmful Algae 49, 68-93. doi: 10.1016/j.hal.2015.07.009

Whitmore, T. J., Riedinger-Whitmore, M. A., Reed, Z. E., Curtis, J. H., Yang, H., Evans, D. E., et al. (2020). Paleolimnological assessment of six lakes on the Kissimmee Chain, with implications for restoration of the KissimmeeOkeechobee-Everglades system, Florida, USA. Lake Reserv. Manage. 36, $218-$ 242. doi: $10.1080 / 10402381.2020 .1785064$

Wilhelm, S., and Adrian, R. (2008). Impact of summer warming on the thermal characteristics of a polymictic lake and consequences for oxygen, nutrients and phytoplankton. Freshw. Biol. 53, 226-237. doi: 10.1111/j.1365-2427.2007.01887. $\mathrm{x}$

Williams, C. D., Aubel, M. T., Chapman, A. D., and D'Aiuto, P. E. (2007). Identification of cyanobacterial toxins in Florida's freshwater systems. Lake Reserv. Manage. 23, 144-152. doi: 10.1080/07438140709353917

Winder, M., and Schindler, D. E. (2004). Climate change uncouples trophic interactions in an aquatic ecosystem. Ecology 85, 2100-2106. doi: 10.1890/040151

Wood, S. A., and Dietrich, D. R. (2011). Quantitative assessment of aerosolized cyanobacterial toxins at two New Zealand lakes. J. Environ. Monit. 13, 16171624. doi: $10.1039 / \mathrm{clem} 10102 \mathrm{a}$

Wood, S. A., Kelly, L. T., Bouma-Gregson, K., Humbert, J. F., Laughinghouse, H. D. Iv, Lazorchak, J., et al. (2020). Toxic benthic freshwater cyanobacterial proliferations: challenges and solutions for enhancing knowledge and improving monitoring and mitigation. Freshw. Biol. 65, 1824-1842. doi: 10. $1111 /$ fwb. 13532

Wood, S. A., Rueckert, A., Hamilton, D. P., Cary, S. C., and Dietrich, D. R. (2011). Switching toxin production on and off: intermittent microcystin synthesis in 
a Microcystis bloom. Environ. Microbiol. Rep. 3, 118-124. doi: 10.1111/j.17582229.2010.00196.x

Work, T. M., Barr, B., Beale, A. M., Fritz, L., Quilliam, M. A., and Wright, J. L. (1993a). Epidemiology of domoic acid poisoning in brown pelicans (Pelecanus occidentalis) and Brandt's cormorants (Phalacrocorax penicillatus) in California. J. Zoo Wildl. Med. 24, 54-62.

Work, T. M., Beale, A., Fritz, L., Quilliam, M., Silver, M., Buck, K., et al. (1993b). Domoic acid Intoxication of Brown Pelicans and Cormorants in Santa Cruz, California. Available online at: https://www.tib.eu/de/suchen/id/BLCP\% 3ACN004688727 (accessed December 1, 2000).

World Health Organization (1993). Guidelines for Drinking-Water Quality, 2nd Edn. Geneva: World Health Organization.

Wu, X., Yan, Y., Wang, P., Ni, L., Gao, J., and Dai, R. (2015). Effect of urea on growth and microcystins production of Microcystis aeruginosa. Bioresour. Technol. 181, 72-77. doi: 10.1016/j.biortech.2015.01.035

Xu, H., Jiang, H., Yu, G., and Yang, L. (2014). Towards understanding the role of extracellular polymeric substances in cyanobacterial Microcystis aggregation and mucilaginous bloom formation. Chemosphere 117, 815-822. doi: 10.1016/j. chemosphere.2014.10.061

Xu, H., Paerl, H. W., Qin, B. Q., Zhu, G. W., and Gao, G. (2010). Nitrogen and phosphorus inputs control phytoplankton growth in eutrophic Lake Taihu, China. Limnol. Oceanogr. 55, 420-432. doi: 10.4319/lo.2010.55.1.0420

Yan, D., Xu, H., Lan, J., Yang, M., Wang, F., Hou, W., et al. (2020). Warming favors subtropical lake cyanobacterial biomass increasing. Sci. Total Environ. 726:138606. doi: 10.1016/j.scitotenv.2020.138606

Yasumoto, T., Nakajima, I., Bagnis, R., and Adachi, R. (1977). Finding of a dinoflagellate as a likely culprit of ciguatera. Bull. Jpn. Soc. Sci. Fish 43, 10211026.

Yeeting, B. (2009). Ciguatera-like fish poisoning from giant clams on Emao Island, Vanuatu. SPC Fish. Newsl. 129, 13-16.
Yentsch, C., Lapointe, B., Poulton, N., and Phinney, D. (2008). Anatomy of a red tide bloom off the southwest coast of Florida. Harmful Algae 7, 817-826. doi: 10.1016/j.hal.2008.04.008

Yñiguez, A. T., Lim, P. T., Leaw, C. P., Jipanin, S. J., Iwataki, M., Benico, G., et al. (2020). Over 30 years of HABs in the Philippines and Malaysia: What have we learned? Harmful Algae 23:101776.

Yoo, K. (1991). Population dynamics of dinoflagellate community in Masan Bay with a note on the impact of environmental parameters. Mar. Pollut. Bull. 23, 185-188. doi: 10.1016/0025-326X(91)90672-F

Zanchett, G., and Oliveira-Filho, E. C. (2013). Cyanobacteria and cyanotoxins: from impacts on aquatic ecosystems and human health to anticarcinogenic effects. Toxins 5, 1896-1917.

Zohdi, E., and Abbaspour, M. (2019). Harmful algal blooms (red tide): a review of causes, impacts and approaches to monitoring and prediction. Int. J. Environ. Sci. Technol. 16, 1789-1806.

Zonneveld, K. A., Marret, F., Versteegh, G. J., Bogus, K., Bonnet, S., Bouimetarhan, I., et al. (2013). Atlas of modern dinoflagellate cyst distribution based on 2405 data points. Rev. Palaeobot. Palynol. 191, 1-197. doi: 10.1016/j.revpalbo.2012. 08.003

Conflict of Interest: The authors declare that the research was conducted in the absence of any commercial or financial relationships that could be construed as a potential conflict of interest.

Copyright $\odot 2021$ Heil and Muni-Morgan. This is an open-access article distributed under the terms of the Creative Commons Attribution License (CC BY). The use, distribution or reproduction in other forums is permitted, provided the original author(s) and the copyright owner(s) are credited and that the original publication in this journal is cited, in accordance with accepted academic practice. No use, distribution or reproduction is permitted which does not comply with these terms. 